\title{
Energy
}

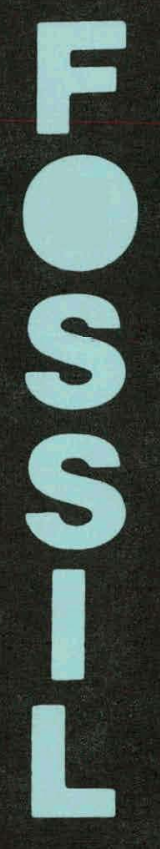

\section{EDS COAL LIQUEFACTION PROCESS DEVELOPMENT}

Phase 5, Engineering Design Study of an EDS Illinois Bottoms Fired Hybrid Boiler, Interim Report

April 1984

Work Performed Under Contract No. FC05-77ET10069

Exxon Research and Engineering Company

Florham Park, New Jersey

Technical Information Center

Office of Scientific and Technical Information United States Department of Energy 


\section{DISCLAIMER}

This report was prepared as an account of work sponsored by an agency of the United States Government. Neither the United States Government nor any agency Thereof, nor any of their employees, makes any warranty, express or implied, or assumes any legal liability or responsibility for the accuracy, completeness, or usefulness of any information, apparatus, product, or process disclosed, or represents that its use would not infringe privately owned rights. Reference herein to any specific commercial product, process, or service by trade name, trademark, manufacturer, or otherwise does not necessarily constitute or imply its endorsement, recommendation, or favoring by the United States Government or any agency thereof. The views and opinions of authors expressed herein do not necessarily state or reflect those of the United States Government or any agency thereof. 


\section{DISCLAIMER}

Portions of this document may be illegible in electronic image products. Images are produced from the best available original document. 


\title{
DISCLAIMER
}

\begin{abstract}
This report was prepared as an account of work sponsored by an agency of the United States Government. Neither the United States Government nor any agency thereof, nor any of their employees, makes any warranty, express or implied, or assumes any legal liability or responsibility for the accuracy, completeness, or usefulness of any information, apparatus, product, or process disclosed, or represents that its use would not infringe privately owned rights. Reference herein to any specific commercial product, process, or service by trade name, trademark, manufacturer, or otherwise does not necessarily constitute or imply its endorsement, recommendation, or favoring by the United States Government or any agency thereof. The views and opinions of authors expressed herein do not necessarily state or reflect those of the United States Government or any agency thereof.
\end{abstract}

This report has been reproduced directly from the best available copy.

Available from the National Technical Information Service, U. S. Department of Commerce, Springfield, Virginia 22161.

Price: Printed Copy A06

Microfiche A01

Codes are used for pricing all publications. The code is determined by the number of pages in the publication. Information pertaining to the pricing codes can be found in the current issues of the following publications, which are generally available in most libraries: Energy Research Abstracts (ERA); Government Reports Announcements and Index (GRA and I); Scientific and Technical Abstract Reports (STAR); and publication NTIS-PR-360 available from NTIS at the above address. 
EDS COAL LIQUEFACTION PROCESS DEVELOPMENT

\author{
PHASE V \\ Engineering Design Study of an EDS \\ Illinols Bot toms Fired Hybrid Boller \\ Interim Report \\ Report Prepared by \\ COMBUSTION ENGINEERING, INC.
}

Apr 111984

\begin{abstract}
PREPARED FOR
UNITED STATES DEPARTMENT OF ENERGY

UNDER COOPERATIVE AGREEMENT NO. DE-FCO5-77ET10069
\end{abstract}

\author{
W. R. Epperly - Project Director \\ Exxon Research and Englneering Company \\ P. 0. Box 101 \\ Florham Park, New Jersey 07932
}

\author{
A Project Jointly Sponsored By \\ United States Department of Energy \\ Exxon Company, U.S.A. \\ Electric Power Research Institute \\ Japan Coal Liquefaction Development Company \\ Ph1111ps Coal Company \\ Anaconda Minerals Company \\ Ruhrkohle AG \\ ENI
}


ABSTRACT

This is an interim technical progress report for U.S. Department of Energy Cooperative Agreement No. DE-FC05-77ET10069, EDS Coal Liquefaction Process Development - Phase V. Funding is shared by U.S. Department of Energy, Exxon Company, U.S.A. (a division of Exxon Corporation), Electric Power Research Institute, Japan Coal Liquefaction Development Company, Phillips Coal Company, Anaconda Minerals Company, Ruhrkohle A.G., and ENI. This agreement covers the period January 1, 1977 through December 31, 1985.

This interim report documents work carried out by Combustion Engineering, Inc. under a contract to Exxon Research and Engineering Company and was prepared by Combustion Engineering, Inc. This report is the second of two reports by Combustion Engineering, Inc. on the predevelopment phase of the Hybrid Boiler program and covers the results of an engineering design study of a Hybrid Boller firing the vacuum distillation residue (vacuum bot toms) derived from processing Illinois No. 6 coal in the EDS Coal Liquefaction Process. The function of the Hybrid Boiler is to heat the coal slurry feed for an EDS coal liquefaction plant by a process coil in the convection section and to generate high pressure steam in the radiant section. The Hybrid Boiler design developed in this phase of the program is based on the results of a laboratory characterization program (reported in EDS Interim Report FE-2893-112), on Combustion Engineering, Inc.'s extensive experience as a designer and supplier of steam generating equipment, and on Exxon Research and Engineering Co.'s experience with the design and operation of process heaters. 


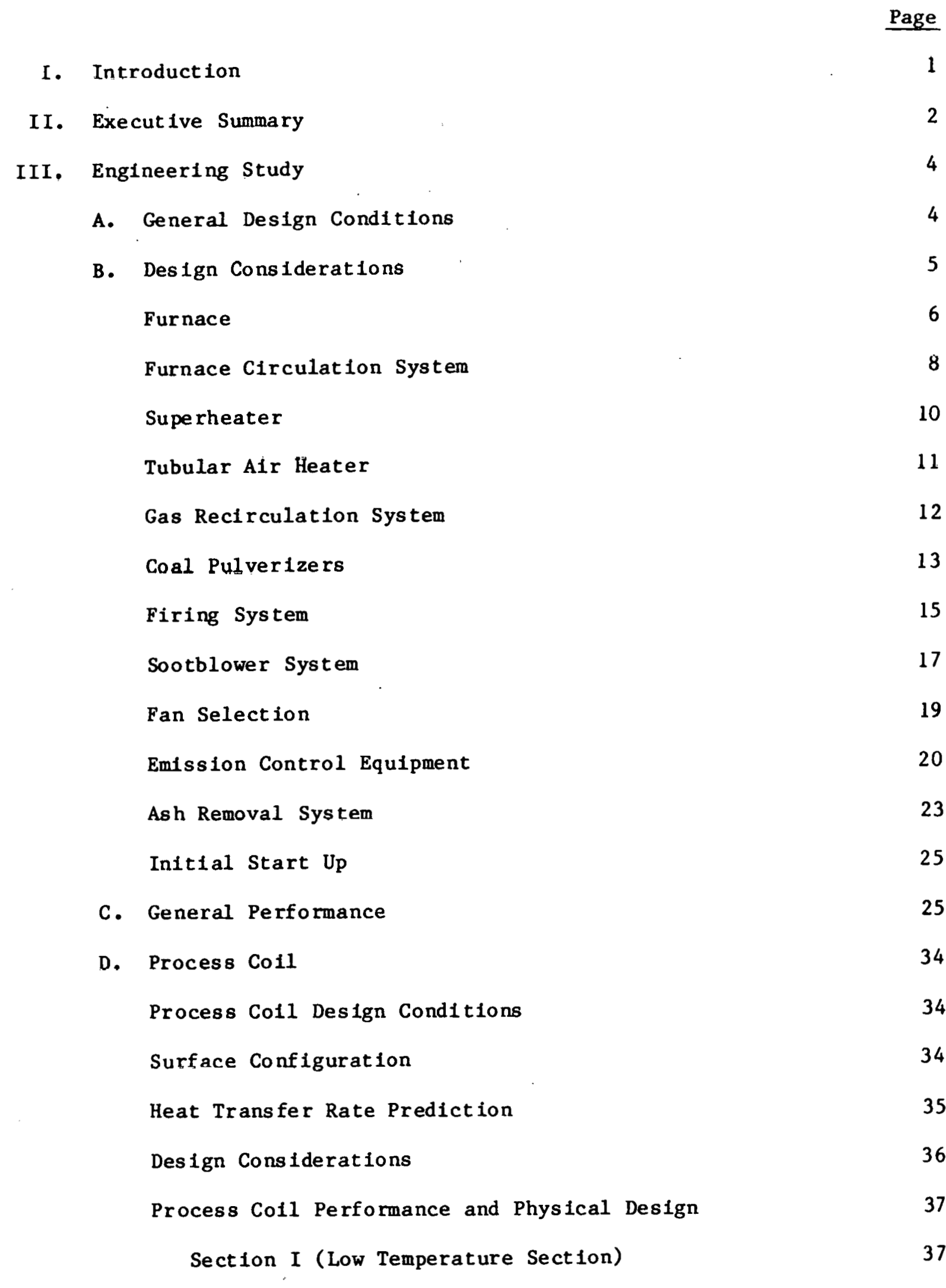


Section II (Intermediate Temperature Section) 38

$\begin{array}{ll}\text { Section III (HIgh Temperature Section) } & 38\end{array}$

$\begin{array}{ll}\text { Flow Unbalance and Gas Bypassing } & 38\end{array}$

Process Coil Roof Tube Support $\quad 39$

Operational Considerations 41

Decoking $\quad 41$

E. Availability Analysis $\quad 44$

F. Cost Estimate $\quad 46$

$\begin{array}{ll}\text { Scope of Equipment } & 46\end{array}$

Boiler Island $\quad 46$

$\begin{array}{ll}\text { Precipitators } & 46\end{array}$

Flue Gas Desulfurization Island. $\quad 47$

$\begin{array}{ll}\text { Pricing } & 47\end{array}$

G. Equipment Specifications $\quad 48$

Section I - Coal Preparation 49

Coal Silos $\quad 50$

Pulverizers $\quad 51$

Section II - Fuel Firing 54

Tangent1al Fired Windbox 55

Furnace Safeguard Supervisory System $\quad 59$

Section III - Steam Generator and Process Coll 60

$\begin{array}{ll}\text { Drum } & 61\end{array}$

Furnace Wall Systems $\quad 63$

Steam Cooled Wall System- $\quad 64$

Superheater, Process Coil and
Economizer 
Process Co11

Desuperheater

Section IV - Auxiliary Equipment 76

$\begin{array}{ll}\text { Secondary A1r Heater } & 77\end{array}$

$\begin{array}{ll}\text { Fans } & 79\end{array}$

Gas Recirculation System $\quad 80$

$\begin{array}{ll}\text { Ductwork } & 81\end{array}$

Sootblowing System $\quad 82$

Stagk $\quad 83$

Section V - Flue Gas Clean Up System 84

Electrostatic Precipitator 85

EDS Hybrid Boiler (Illinois)

Wet Scrubber-Scope of Supply $\quad 87$

Bottom Ash, Process Coil Ash and

Pulverizer Rejects Removal System 88

Pneumatic Flyash Removal System $\quad 92$

Section VI - List of D̈rawlngs 95

Boller Ash and Mill Rejects

Removal-Hybrid Boiler

Arrangement of C-E Rotary Ash

Condit Ioner-Model 36-Standard

Process Coil Support

General Arrangement and Plan View

Hylidd Boiler-Illinoio Design

100

Afr and Gas Flow Schematic-Boller Hybrid Boiler-Illlnois EDS Design 
Table 1 - Fuel Analysis EDS Residue Illinois Parent Coal

Table 2 - Fuel Analysis EDS Residue Illinois Parent Coal

Table 3 - General Des1gn Conditions

Table 4 - EDS Hybrid Boiler Illinois Coal

EDS Residue Predicted Performance

Table 5 - EDS Hybrid Boiler Illinois Coal EDS Residue Circulation System Predicted Pe rformance

Table 6 - Partial List of C-E Coal Fired Units With Tubular Air Heaters and No Air Heater Sootblowing

Table 7 - Comparıson of Backpass Design Flue Gas Temperatures and Velocities for Typical C-E Coal Fired Units

Table 8 - Full Load Process Coll Performance 
Figure 1 - C-E Pulverizer Type RP 52

Figure 2 - Integral Feeder (L.H.) 53

Figure $3-$ C-E Tangential Windbox 56

Figure $4-$ C-E Tangential Firing Windbox 57

Figure 5 - Typical Water-Cooled Compartment 58

F1gure 6 - Drum Internals Centrifugal Type 62

$\begin{array}{ll}\text { Figure } 7- & \text { EDS Hybrid Boiler-Mass Flow and } \\ \text { Temperature Profiles } & 68\end{array}$

Figure 8 - EDS Hybrid Boiler (Illinols Destgn) 69

$\begin{array}{lll}\text { Figure } 9- & \text { EDS Hybrid Boiler (Illinols Design) } \\ & \text { Process Coil Arrangement }\end{array}$

$\begin{array}{ll}\text { Figure } 10- & \text { EDS Hybrid Botler Illinots EDS } \\ & \text { Process Co11 Arrangement }\end{array}$

Figure 11 - Inside Heat Transfer

Coefficient vs. Bulk Process Temp. 72

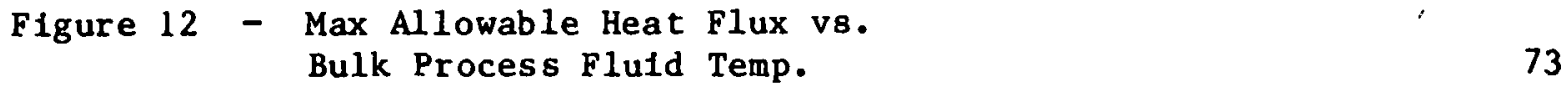

Figure 13 - C-E Desuperheater 75

Figure 14 - C-E Tubular Air Heater 78

Figure $15-C-E$ Walther Precipitator $\quad 86$

Figure 16 - C-E Submerged Scraper Conveyor (SSC) 89

Figure 17 - C-E ABh System Jet Pump 90

Figure 18 - C-E Model 830 Cllnker Grinder 91

Figure 19 - Dual-Cyclone Module 93 


\section{INTRODUCTION}

Combustion Engineering has developed a hybrid boiler design capable of generating steam and providing process heating for the EDS coal 1iquefaction process by burning vacuum bottoms. The design is a result of the Inttial phase of development initiated in May, 1981. The hybrid boller design resulted from the combined knowledge and experience of Combustion Engineering and Exxon Research \& Engineering Co., supplemented by the results from the extensive vacuum bottoms fuel testing program described In FE-2893-112.

The completion of the initial phase of the design study resulted in the detalled design of a hybrid boiler firing Illinols vacuum bottoms and the combustion characteristics of the Illinols vacuum bottoms fuel. The comprehensive Illinols vacuum bottoms test program performed at Combustion Engineering's Krelsinger Development Laboratory determined the vacuun bottoms pulverization, combustion, fouling, and slagging character1stics. The detalled design of the hybrid boller included unit per formance, equipment selection and a cost estimate for the boiler island. The boiler island scope includes; bollers, pulverizers, firing system, fuel preparation system, FD fans, ID fans, PA fans, a1r heaters, soot blowers, preclpllaturs, $\mathrm{SO}_{2}$ scrubbers, bottom ash pyrites rejects and process coll ash removal system, and flyash removal system. 
The results of the 1981 Hybrid Boiler predevelopment program may be found in the Engineering Study reported here and in the laboratory evaluation reported in FE-2893-112. The Englneering Study focuses on the design and identification of areas for future study of an EDS vacuum bottoms fired Hybrid Boller. The laboratory evaluation assessed the fuel and ash properties of the residue (vacuum bottoms) produced by the EDS coal 11quefaction process.

The primary function of the Hybrid Boiler is to heat the coal slurry feed for an EDS liquefaction plant. This is accomplished by a process coll located in the convection section of the Hybrid Boiler. In addition, the radiant section of the Hybrid Boiler is used to generate high pressure steam for the plant.

The Hybrid Boller design developed under this program is based on the results from a comprehensive combustion testing program in C-E's Fireside Performance Test Fac1lity (FPTF) and Drop Tube Furnace System (DTFS) on the once through ( 1 ow conversion) EDS residue from an Illinois No. 6 coal and less extensive (DTFS) testing on the residue bottoms recycle (high conversion) residue. Both Combustion Engineering's extensive expertence as a designer and supplier of steam generating equipment, and Exxon Research and Engineering Co.'s (ER\&E) extensive experience with the design and operation of process heaters were used in developing the design.

The Hybrid Botler design utilizes a conventional, field proven furnace and superheater design, and standard auxiliary equipment. The Hybrid Boller, however, includes a process coll which is not provided in typical boller designs. Th1s was a major consideration of the program. A second consideration was the fuel nozzle design. Water cooled fuel nozzles were 
specified for the Hybrid Boller because of the low melting point of the residues.

The results of the Laboratory Evaluation affected several areas of the Hybrid Boller design including furnace size, pulverizer size; superheater design, process coll design and firing system design. The combustion testing results indicated that at high temperatures the high conversion Iilinois EDS residue has combustion properties similar to high volatile bituminous coals. However, at low temperatures the combustion testing indicated potential flame instability. The laboratory evaluation also indicates the I111nois EDS residue has the potential to generate NOx levels greater than the parent coal. Slagging and fouling potential of the low conversion residue was not significantly different from that of Illinois \#6 coals. The effect of the higher ash content of the commercial residues was factored into the boller design.

The Hybrid Boller design developed under this program is not a significant departure from conventional coal fired steam generating unit designs. Combustion Engineering would design and fabricate a Hybrid Boiler with commerclal guarantees. The following budget pricing was developed for four units operating in parallel at an Illinols plant site:

$\begin{array}{lrr} & \frac{\text { Delivered }}{\text { Four (1) Hybrid Boilers }} & \text { Dellvered \& Erected } \\ \text { Flue Gas Clean up System } & 32,220,000 & \$ 225,900,000 \\ \quad \text { (For Four Hybrid Bollers) } & 50,000,000 \\ \text { Total } & \end{array}$




\section{III • ENGINEERING STUDY}

\section{A. General Design Conditions}

The hybrid boller general design conditions for Illinois EDS vacuum bottoms are tabulated below. Additional predicted performance data may be found in Section C, "Summary of Performance Conditions".

Number of Units:

Steam Capacity:

SHO Pressure:

SHO Temperature:

Feedwater Temperature:

Process Fluid Flow:

Process Flutd Pressure:

Process Fluid Outlet Temperature:

Process Fluid Inlet Temperature:

Process Coil Heat Absorption Rate:

Steam/Process Fluid Heat Duty Ratio:

Sulfur Remova 1:

Particulate In Flue Gas:

NOx In Flue Gas:

Vacuum Bottoms Surface Moisture:

Unit Turn Down:
Four (4)

$487,200 \mathrm{lb} / \mathrm{hr}$

$1250 \mathrm{psig}$

$925^{\circ} \mathrm{F}$

$250^{\circ} \mathrm{F}$

$2,170,0001 \mathrm{~b} / \mathrm{hr}$

2500 psig

$840^{\circ} \mathrm{F}$

$413^{\circ} \mathrm{F}$

$600 \mathrm{MBtu} / \mathrm{hr}$

$50 \% / 50 \%$

$90 \%$

$0.031 \mathrm{bs} /$ MBtu Fired

$0.61 \mathrm{bs} / \mathrm{MBtu}$ Fired

$2 \%$ by Weight

$50 \%$ while maintaining

$840^{\circ} \mathrm{F}$ process coil

out let temperature 


\section{B. Design Considerations}

The hybrid boller may be regarded as a typical coal fired boiler modified to accommodate the requirements of the process coil. The heat exchanger containing the three (3) phase fluid (donor solvent, coal and hydrogen) is referred to as the process coil. Several unusual constraints and/or criteria imposed on the hybrid boiler design are addressed. One constraint is the size of the process coll in relation to normal heat absorbing surfaces. A second criterion is that the hybrid boiler must be designed to allow decoking of the process coil. During decoking, the process coll and internal decoking steam will reach $1300^{\circ} \mathrm{F}$ requiring spectal material and support designs. A third consideration is the high ash content in the vacuum bottoms. The ash content may be as high as 30 percent requiring design considerations to reduce the effects of erosion throughout the unit. A fourth consideration was the combustion characteristics of the EDS vacuum bottoms. The fuel preparation system and firing system design reflect these considerations.

There are two other criteria which were considered very carefuliy in the design of the hybrid boller. These are the controllability and rejlability of the unit. Since unit operation must be coordinated with the larger liquefaction process, these factors play an important role in determining the feasibility of the entire project.

The equipment to be designed by C-E includes all the major components of the boller island. This scope fuel preparation system includes the furnace, fuel flring system, superheater, process col1, a1r heater, 
soot blowers, ash handling equipment, fans, electrostatic precipitator, flue gas desulfurization, ducts, dampers, and support steel.

The hybrid boiler design basis was specified by the Exxon Research and Engineering Company at the initial technical meetings held in March and April of ${ }^{*} 1981$. These design conditions are tabulated in Section C, General Performance. These general conditions plus results for the laboratory testing of the vacuum bottoms, determined the parameters for the unit design. One important design parameter that affected the overall design of the hybrid boller was the constraint of a $50 \% / 50 \%$ split of heat duty between the process coil and the furnace and superheaters. This heat duty constraint directly affected furnace size, superheaters and process coll surface areas and surface arrangement. For coal fired bollers, heat absorption in the furnace and superheater approaches $70 \%$ of the total heat absorbed in the unit. In order to attain the appropriate split of heat duty without sacrificing a conservative furnace design, the use of gas recirculation was employed to reduce the heat absorption in the furnace and increase the heat absorption in the process $\operatorname{col} 1$.

\section{$\underline{\text { Furnace }}$}

The hybrid boller w111 be a natural circulation type unit with fustion welded furnace waterwalis. The furnace for the hybrid boiler is defined as the area enclosed by waterwall extending to the leading edge of the low temperature pendant superheater located above the furnace nose.

For vacuum bottoms firing, the furnace configuration becomes an important factor for proper operation. The characteristics of the fuel which includes slagging and fouling tendencles, flame stability and 
burnout rate have to be analyzed so that the furnace dimenstons are properly sized. The two basic parameters to furnace sizing are the cross-sectional (plan) area and the furnace height. A factor for heat flux to the walls called the Net Heat Input per Plan Area (NHI/PA $x$ $10^{6} \mathrm{Btu} / \mathrm{hr}^{-\mathrm{Ft}^{2}}$ ) is used to determine the cross-sectional area.

The vacuum bottoms will behave similar to a typical midwestern bituminous coal. Laboratory test results have indicated that the vacuum bottoms will exhibit slagging and fouling characterlstics similar to a midwestern bituminous coal which is currently being fired at the Illinois Power Company, Baldwin Power Station. This station is operating at its NHI/PA design value of 1.9 with the Baldwin coal. Values for NHI/PA of up to 1.85 are currently used for midwestern bituminous coals. Normal utility design practice requires that a unit be designed to allow removal of slag at full load. The hybrid boiler furnace was conservatively designed using an NHI/PA of 1.4 . The lower value provides a larger area for heat absorption, reducing the heat flux on the furnace walls. A smaller plan area (or higher NHI/PA) results in higher heat absorption by the furnace walls. The higher furnace gas temperatures cause the furnace deposits to bond more firmly to the tubes and also increases the tendency for slag to become fluid. The combination of higher bonding strength and fluid slag makes it difficult for the furnace wall blowers to remove the deposits. A larger furnace plan area provides more area for the ash to deposit, reducing deposit thickness resulting in easter removal and longer sootblower inlexvals.

A furnace height of $93.8 \mathrm{ft}$. was selected to provide adequate retention time of the fuel particle to ensure carbon burnout. The average 
retention time for the fuel in the furnace is approximately 1.9 seconds. Furnace height is also affected by the slagging characteristics of the fuel. The results from the laboratory testing have indicated the vacuum bottoms to be a slagging coal. Additional furnace height, therefore, has been included between the lowest fuel admission point in the furnace and the upper bend line of the water cooled coutant hopper section. The additional furnace waterwall surface in this area will lower heat absorption rates by increasing surface area, avold running slag onto the sloped hopper section, and avold bridging over the coutant opening.

The conservative design of the hybrid boiler furnace which minimizes the furnace wall slagging potential and maximizes carbon burnout can affect furnace turndown. The furnace gas combustion zone temperatures are predicted to be in the $2200^{\circ} \mathrm{F}$ range at low loads. The laboratory combustion test results indicate that in the Drop Tube Furnace system Test Faclity (DTFS) combustion instability could occur below gas temperatures of 2100 to $2000^{\circ} \mathrm{F}$. As discussed in the Fuel Firing System section, C-E currently predicts a 50\% MCR load can be achieved without support fuel. Below $50 \%$ load support fuel may be required to avold flame/1gnition instability.

Furnace Circulation System

A natural circulation system operating at 1350 psig has been selected for the hybrid boller. C-E has built units with drum operating pressures up to 2400 psig utilizing natural circulation. The furnace waterwall system and drum specification are tabulated in the Section I, Equipment Specifications. A drum (Fig. 6) size of 60 inches (internal diameter) was specified. The maximum capacity of the drum with SHO 
steam conditions of $1250 \mathrm{psig}$ and $925^{\circ} \mathrm{F}$ is $600,0001 \mathrm{~b} / \mathrm{hr}$ of steam, which is $23 \%$ above MCR capacity.

Natural or thermal circulation results from a density difference between the subcooled water in the downcomers and the saturated steamwater mixture in the furnace wall tubes. Subcooled feedwater is introduced in the steam drum where it locally mixes with recirculated saturated water. The liquid phase entering the downcomers is slightly subcooled. This water flows from the downcomers into a lower ring header, which feeds the furnace wall tubes. These tubes form the walls of the furnace enclosure, and the subcooled water is heated to saturation and steam is produced as the fluid rises in the tubes. A saturated steam-water mixture is collected in upper, headers, leaves the furnace through relief tubes and enters the steam drum. In the drum, mechanical separation of the steam from the steam-water mixture occurs. The dry saturated steam passes from the drum to the superheater sections. The saturated water remains in the drum and is avallable for recirculation.

Overheating of furnace wall tubes can occur when either the heat flux is sufficiently high to cause departure from nucleate boiling (DNB) or if the overall exit quality of the steam is high enough to cause drying of the inner tube surface. The heat flux necessary for DNB increases as operating pressures decrease: At the design pressure and heat release rate used in the furnace design, DNB will not occur in the hybrid unit. The overall circulation ratio (Table 5) developed in the hybrid boiler ensures that the tubes will be wetted at the point of maximum steam quality.

The other main consideration in the design of the circulation system is 
the efflciency of the steam-water separation process occurring in the drum. For a fixed drum pressure, a minimum pressure drop is required for the mixture passing through the internals to provide dry steam. Both the overall circulation ratio and the velocity in the waterwall relief tubes play dominant roles in this desired pressure drop. The hybrid unit is designed so that proper steam separation occurs.

\section{$\underline{\text { Superheater }}$}

The superheater for the hybrid boller consists of three sections and is similar to conventional utility units. The first section consists of the encasement for the process coll referred to as a steam cooled backpass. Virtually all utility designs consist of a steam cooled backpass utilizing saturated steam to cool the walls in areas where gas temperatures w11l be above $1000^{\circ} \mathrm{F}$. In the case of the hybrid boller, saturated steam w111 be taken off the drum and piped to backpass headers where the steam will pass through tubes surrounding the process coll.

From the backpass, the steam travels to the pendant superheater located above the nose arch in the furnace. The steam w111 pass through the front low temperature pendant, then to a desuperheater (Fig. 7) before reaching the high temperature finishing pendant section. The desuperheater serves as the primary control mechanism for the steam tèmpèraturé.

The low temperature pendant superheater will consist of twelve (12) assemblies spaced on 30 inch centers across the width of the untt. The depth spacing of each assembly will be closely spaced with only 3/8" clear between tubes. This design is known as platenized construction and is used in high gas temperature zones in the superheater. The 
platenized construction minimizes the ash bulldup on the superheater tubes, allows normal ash deposits to build up on the superheater tubes without bridging across the assemblies.

The high temperature pendant section design was based on a balance between steam pressure drop and surface requirements. The depth spacing is two times the tube diameter allowing for use of the full circumference of the tube as effective heat absorbing surface. The fouling tendencies of this section will be less than the low temperature pendant since it is in a lower gas temperature zone. The width spacing of this section will be 18 inches between 20 assemblies which is still very conservative and will not pose bridging problems with regular use of the sootblowers.

Tubular Air Heater

A tubular air heater (Fig. 8) is placed after the process coil. for final heat recovery from the flue gas. The flue gas temperature leaving the process coll during normal full load operation will be approximately $560^{\circ} \mathrm{F}$. The air heater transfers this recovered heat to the secondary combustion air and lowers the flue gas temperature to $300^{\circ} \mathrm{F}$. The exit flue gas temperature is 1 imited by the $\mathrm{SO}_{2}$ dewpoint due to corrosion considerations. The tubular air heater designed for the hybrid boiler consists of a three pass arrangement with air passing on the shell side and gas through the tubes. A steam coil air preheater has been included to allow the cold air entering the tubular air preheater to be preheated to avoid condensation on the tube gas side when operating at low loads or during periods of low ambient temperatures. Thermocouples placed on several cold end tubes will 
allow continuous monitoring of the cold end tube temperatures in the control room:

Recuperative (tubular) air heaters were chosen in lieu of a regenerat1ve (Ljungstrom type) air heaters due to design considerations of the process coll. If a process coll tube were to develop a leak, the Elammable process fluid would leak into the backpass and mix with the flue gas. The flue gas, having an $\mathrm{O}_{2}$ content less than $4 \%$, should not cause any immediate problems, but if mixed with air, the potenti.al for 1 gnition would increase. To minlmize the potential of combustion of the flammable material from a leaking process coll tube, isolation from a high oxygen environment is desirable. Recuperative (tubular) air heaters will keep the air and gas streams separated. This contrasts with a regenerative system where an air leakage into the flue gas is unavoidable. $\mathrm{C}-\mathrm{E}$ recommends that tubular air heaters be incorporated into the design of the hybrid boller for the reason that it offers the safest design for the specifled operating conditions.

\section{Gas Recirculation System}

The characteristics of the hybrid boller design warrants the use of a gas recirculation system. The design heat duty of $600 \mathrm{MBtu}$ 's in each of the steam and process coll sections requires that the heat absorption distribution parameters be altered. In a typical coal fired steam generator approximately $70 \%$ of the heat is absorbed in the furnace and superheater sections. In order to shift the heat absorbed from the furnace to the process coil, gas recirculation is necessary. When using gas recirculation, cooler flue gas is admitted to the furnace. The additional flue gas absorbs some heat that would normally be absorbed by the furnace walls and superheater and carries 
this heat over to the process coil. The greater mass of flue gas transfers this heat to the process coll by increasing convective transfer rate. With the characteristics portrayed by the Illinots EnS hybrid boiler, a $30 \%$ gas recirculation rate is required to achieve the desired absorption profile.

The vacuum bottoms fired in the hybrid boiler will contain a substantial quantity of ash, up to 30 percent by weight. The flyash carryover will be equivalent to units firing high ash coals. Recirculating dirty flue gas would compound the quantity of flyash carryover increasing the rate of erosion of convective tubing throughout the unit. For the hybrid boiler design, the flue gas wij.l be recirculated from the induced draft fan outlet which is located downstream of the electrostatic precipitator. The clean flue gas will. be ducted to the furnace and introduced through openings in the furnace hopper coutant bottom as shown on the drawing No. EP-813-199. The flow of the recirculated gas will be regulated by louver dampers located in the duct. The available induced draft fan discharge pressure at all loads will be suitable to recirculate flue gas through the furnace bottom. This will eliminate the need for a separate flue gas recirculation fan. Experience has shown that high temperature gas recirculation fans have high maintenance and low availability tendencles.

\section{Coal Pulverizers}

The fuel pulverizing system for the Illinois EDS plant is capable of grinding both vacuum bottoms and the parent Illinois midwest bituminous coa1. Four C-E Raymond Type RP Bowl Mills (Fig. 1) and four integral volumetric feeders (Fig. 2) will be provided. Each pulverizer is 
capable of grinding either vacuum bottoms or the parent Illinois bituminous coal. The pulverizing system will be capable of grinding the required quantity of vacuum bottoms to achieve the $100 \% \mathrm{MCR}$ condition with three of the four pulverizers in service. With three pulverizers in service grinding the parent coal, a $57 \%$ MCR load can be achieved.

Each mill will pass $80 \%$ by welght of vacuum bottoms through 200 mesh (200 openings per inch) with a Hardgrove grindability of $100+$ and will draw $132 \mathrm{kw}$ based on a capacity of $41,000 \mathrm{lb} / \mathrm{hr}$ per mill. When grinding the parent coal, each mill will pass $70 \%$ by weight through 200 mesh with a Hardgrove grindability of 53.5 and will draw $80 \mathrm{kw}$ based on a capacity of $14,8751 \mathrm{~b} / \mathrm{hr}$ per mill.

Bench scale testing of the Illinols high ash vacuum bottums showed some tendency toward pasting. However, pulverization tests indicate the Illinois high ash vacuum bottoms can be sucessfully pulverized in a C-E bowl mill without the use of any special conditions.

The pulverizer system will be pressurized by two primary alr fans which provide transport and drying (if required) alr for the fuel. Each primary air fan will discharge to the primary air steam air heater which in turn will discharge to a common duct which serves all four pulverizers. Each fan is capable of providing the transport air required to reach $67 \%$ of $M C$ R capacity firing vacuum bottoms. If one primary air fan is out of service supplemental fuel gas can be fired at a firing rate of $33 \%$ MCR to maintain full load conditions.

Normal operation with the vacuum bottoms will not require the use of preheated air to the pulverizer due to the extremely low molsture 
content of the vacuum bottoms. With the steam air preheating system, the mflling system can also handle additional surface moisture on the vacuum bottoms if required. Vacuum bottoms firing will require a transport air to fuel ratio of $1.3: 1.0$. When firing the parent coal, a minimum primary air temperature of $450^{\circ} \mathrm{F}$ with a transport air to fuel ratio of $2.5: 1.0$ is required to adequately dry the coal. Alternately the parent coal throughout can be increased if a higher primary air temperature is available. The single steam coil air heater installed in the primary air duct will provide the heat for the parent coal primary air.

C-E has included a steam inerting system and fire detection system for the pulverizers to snuff out any mill fires which may occur. Some coals have self-heating tendencies making them very reactive and they can Ignite at lower temperatures. These characteristics can be seen primarily in western coals, especially lignites but they exist in all coals. The potential exists for a pulverizer fire or puff with both the parent coal and vacuum bottoms. As an additional measure of unit reliabiity, a steam inerting system has been included as part of the equipment supplied with the pulverizer firing system. A mill fire or puff can result in damage to the mill, components and the coal piping.

\section{Firing System}

The firing system for the hybrid boller consists of four (4) tilting tangengial windbox assemblies (Fig. 4). These windboxes (Fig. 3) are located near each of the four corners of the furnace. Each windbox assembly consists of, four(4) solid fuel admission compartments, two (2) warm-up gas/secondary air compartments, three (3) secondary air compartments and two (2) overfire air compartments, arranged 
horizontally. Located in the furnace wall near each of these windboxes are three (3) self-monitoring gas 1 gnitors and four (4) flame scanners.

These compartments are aimed tangentially to a small, imaginary circle in the furnace. This tangential firing produces mutually supporting fire streams and merges to create a swirling fireball within the furnace cavity. The tangential firing system inherently produces a low level of NOx. Diversion of up to $20 \%$ of the combustion air from the point at which devolatilization occurs decreases fuel NOx production and the lower temperatures associated with the fireball combustion reduces the production of thermal. NOx. NOx production is further discussed in the Emission Control Equipment section.

The compartments in the windboxes have the capability of vertically tilting through a $60^{\circ}$ arc. This tilting is performed simultaneously by all compartments in the furnace keeping them all at the same angle with respect to the horizontal. This tilting allows the heat absorption distribution in the hybrid boiler to be altered. Tilting of the compartments upward will reduce absorption of heat in the furnace and increase the radiant heat transfer to the superheat sections and increase the furnace outlet temperature of the gas. Tilting is one of the two methods of process fluid temperature control in the hybrid boller. Gas recirculation, the other method of process fluid temperature control, has previously been discussed.

Testing of the high ash residue and the low ash residue has been performed in the Kreisigner Development Laboratory (KDL). Several firing system design and operating considerations resulting from the testing have been incorporated in the design of the hybrid boller. 
KDL has found that the residues have a low melting point $\left(300^{\circ} \mathrm{F}-\right.$ $\left.400^{\circ} \mathrm{F}\right)$. This indicates that the incoming residue will undergo a phase change when passing through the nozzle assemblies. It is possible that residue deposits could buld up on the nozzles resulting In partial or total blockage of the passage and coking of the deposited material. Water cooled fuel nozzles (Fig. 5) will be used in the hybrid boller to minimize residue build up/coking.

Combustion of pulverized solid fuel in the furnace has two distinct phases. First, the volatile matter in the fuel evolves and ignites as the fuel is first exposed to the heat in the furnace. After this rapid devolatilization, the remalning char burns out over a relatively longer period of tfme. Work at KDL indicates that at temperatures less than $2300^{\circ} \mathrm{F}$ the commercial high ash residue volatile matter ignites and burns more slowly than that from the low ash residue or the comparison Kentucky bituminous coal.

The slow devolatilization and burning of the high ash residue leads to some concern about flame stability at reduced boller loads where the gas temperatures present in the fireball might be low enough to delay the ignition. Furnace gas temperature predictions indicate that at the control load of $50 \%$ MCR, the high ash residue can be successfully fired without the use of support fuel. As load is further reduced toward $40 \%$ however, it is expected that support fuel will have to be used to maintain stable firing conditions.

Sootblower System

The sootblower system is a very important aspect of any coal fired steam generator. There are two major systems for the hybrid boller. The first system is the furnace wall blower system used for removing 
slag deposits on the radiant furnace walls. Second, the convective sootblower system is located in the superheater and process coll regton for the removal of flyash deposits. The blowing medium for the wall blowers and convective region retractable sootblowers will be steam taken off the low temperature superheater outlet header.

An extensive furnace wall blower system whose coverage is shown on the general arrangement drawing has been provided. Three elevations of wall blowers above the windbox elevation and two elevations of wall blowers below the windbox elevation has been spectfied. Due to the high slagging potential of vacuum bottom ash, this extensive wall blower system and regular sootblower operation is required to prevent slag build up and to remove the furnace wall deposits before they become plastic. The laboratory testing has indicated the vacuum bottoms ash deposits in the furnace tend to have high bonding strengths and be difficult to remove. The laboratory slagging behavior of the vacuum bottoms ash is simflar to high iron Illinois and Ohio coals with which $C-E$ has experience with successfully controlling furnace wall slag build up.

The convective sootblower arrangement consists of single sided retactable sootblowers located fn the pendant superheater sections and the process coll. The retractable sootblowers traverse the width of the unft spraying steam $360^{\circ}$ in a spiral pattern. Laboratory tests have indicated the vacuum bottoms ash in the convective region has a low fouling potential. However, some deposit build up will occur. It is expected the deposits will be lightly sintered and friable and will have low bonding strengths which will be easy to remove.

C-E does not recommend that a sootblower system be installed to clean 
the tubular air heater. C-E's experience has shown that plugging of the tubes is not a problem unless high sulfur fuel oil is being fired. The gas temperature entering the tubular is well below the ash fusion temperature meaning that the flyash is very dry and powdery and will not stick to the tubes. The tubes in the tubular air heater are stralght with no bends or crevices for ash to accumulate. Example of untts firing a high fouling coal and no provision for tubular air heater cleaning capability are listed in Table 6.

\section{Fan Selection}

The design of the hybrid boller required the consideration of reliability as a major constraint when selecting equipment and equipment arrangements. The fan arrangement to be supplied for each unit was carefully analyzed before a design was selected. In order to reduce the potential for fan trips, redundancy must be incorporated in such a manner as to prevent unit outages yet obtain high fan efficiencies and low power consumption.

There are three sets of fans that control the operation of the unit. These fans include the forced draft (F.D.), induced draft (I.D.), and primary alr (P.A.) fans. The primary air fan supplies the pulverizers with drying and fuel transport air. The forced draft fan supplies heated secondary air to the windbox for combustion. The induced draft fan maintains furnace pressure by pulling the flue gas out of the unit and pushing it through the $\mathrm{SO}_{2}$ removal. equipment and on to the stack. The Induced draft fan also supplies the pressure for the flue gas recirculation system.

C-E analyzed the operational priorities of the EDS process set by ER\&E. One consideration is that a unit trip would disrupt the coal 
11quefaction process and have serious operational consequences. To minimize the potential of a unit shutdown due to a fan trip, C-E has included two forced and Induced draft fans each sized for $60 \%$ of the full load maximum continuous rating (MCR) condition. The two primary air fans are sized to deliver the air flow required by two pulverizers. At $100 \% \mathrm{MCR}$, only three mills are required which will require both P.A. fans to be in operation. With one primary air fan in operation, the unit will be able to reach 67 percent of MCR when firing the vacuum bottoms.

\section{Emission Control Equipment}

The emission control system is comprised of an electrostatic precipitator (ESP) and a wet flue gas desulfurization (FGD) system. Each unit will have 1ts own ESP located after the tubular air heater and before the induced draft fans. All four hybrid bollers will share six FGD modules as shown in the drawing. The Hybrid Boiler system will meet current federal nitrogen oxide (NOx) (.6 1b/106 Btu) requirements.

The electrostatic precipitator provided for the hybrid boller will be of the rigid frame type construction (Fig. 9). Five flelds will be inftially installed leaving space for an additional field in case requirements call for it in the future. The precipitator will be able to meet required emission levels with four of five fields in operation.

The reason for the redundant fields is to insure reliable operation of the ESP and avold periods of capacity reduction due to a fallure of a precipitator electrical field. Since there will not be a back up precipitator, any redundancy must be installed initially. The reliablifty of an ESP is very high and C-E recommends that this 
arrangement be employed in order to meet the rellability conditions desired by ER\&E.

A wet flue gas desulfurization system will. be employed in the hybrid boiler design. Crushed limestone is sprayed into the gas stream in the spray tower as a slurry. The sulfur oxides in the gas stream react with the calcium sulfate and sulfite. The residue falls to the bottom of the tower and is pumped out to a sludge handling system. The clcan flue gas then flows to a steam reheater to heat the water saturated flue gas above the water dew point to avoid water condensation in the ductwork and stack.

Reliability of the design is the focal point of the selection and arrangement. The nature of the water-calcium slurry can cause spray nozzle plugging which will cause the module to be taken out of service when enough spray nozzles become plugged. The flue gas from all four hybrid bollers will flow to the center and feed into another plenum that serves six FGD modules. The purpose of the dual plenum arrangement is to assure even distribution of flue gas to the active modules. Each module will be sized to handle 100 percent MCR gas flow from one hybrid boiler. Four modules would be in service when all four bollers are operating. This would leave two modules out of service efther for maintenance or in a standby mode. This arrangement gives the FGD system a 50 percent redundancy factor adding flexibility and reliabillty to the system. A 50 percent flue gas bypass duct will also be installed for use during start-up or if more than two modules are out of service. The common plenum arrangement allows any boiler FGD scrubber combination and affords the maximum boiler avallability with the Installed equipment. 
The level of NOx produced by the hybrid boiler will be minimized by the design and configuration of the firing system. The firing system is designed to mintmize production of fuel-bound NOx and thermal NOx. Fuel-bound NOx is controlled by driving the conversion of fuel nitrogen compounds to molecular nitrogen in the gas phase under fuel-rich/oxygen starved conditions and minimizes Nox formation. The production of thermal NOx is minimized by reducing peak flame temperatures.

The C-E firing system creates a fuel-rich condition by utilizing staged combustion. The use of overtire air compartments divert approximately $20 \%$ of the total air from the primary combustion $z$ one. Also the ignition point is moved closer to the fuel nozzle by varylng the velocity and quantity of air through the annulus of the fuel compartment. Both of these factors extend the duration of the fuelrich primary combustion zone and reduce the formation of fuel-bound Nox.

Peak flame temperatures are reduced with the C-E firing system by slow mixing of fuel and air in the secondary combustion zone. Slow mixing is inherent with the tangential admission of fuel and air by windbox elevation. Also the addition of overfire air to the upper portion of fireball tends to reduce the mixing of fuel and air. C-E predicts that with the utilization of a standard low NOx firing system a NOx level of $0.51 \mathrm{~b} / \mathrm{milli}$ on Btu fired will not be exceeded. However, laboratory testing performed by $C-E$ on Illinois vacuum bottoms indicates there is a potential for high Nox formation. Based on the results of future testing, a determination will be made whether to retain the conventional firing system design, or to 
implement a low NOx modification such as Low NOx Concentric Firing System (LNCFS), Separating Gas Recirculation (SGR) or Pollution Minimum (PM) burner. These modifications have yet to be supplied in a commercial application in the United States.

\section{Ash Removal System}

Two distinct ash removal systems are incorporated in ti.e hybrid boiler design. The first system removes pulverizer rejects, slag from the furnace bottom and flyash from the process coll. The second system will remove flyash collected in the air heater hopper and flyash in the hoppers located under the ESP fields.

In the first system, pulverizer rejects, such as mineral matter and tramp iron (pyrites), which are rejected from the pulverizer grinding process, are directed into temporary storage tanks (pyrites-reject hoppers). The pulverizer-reject hoppers are pressurized and wet store these materials. Level sensing devices in the hoppers indicate when emptying of the tank is necessary. A grate located in the bottom of the tanks can be opened and the stored material will be sluiced away through the use of jet pumps. Each pulverizer has associated with it, indtvidual, pyrites-reject hoppers, jet pump and transfer lines.

The rejects from each of the pyrites-reject hopers feed into the Bottom Ash Submerged Scraper Conveyor (SSC). An SSC (Fig. 11) consists of a water Impounded trough into which materfal falling through the furnace coutant falls. A continuous removal process is used in the SSC. Chains, connected by angle irons in a continuous ladder arrangement, remove material which has settled to the bottom of the SSC. The chain flight carries the material up a dewatering slope which allows excess water to return to the trough. At the top of the dewatering slope, the 
material, dewatered to $20 \%$ by weight water, drops into a clinker grinder. The clinker grinder reduces the size of the large pieces of fused ash to ease the transport of these waste materials. A second SSC, simflar to the Bottom Ash SSC but without the long dewatering slope, is located under the process coll hopper. This SSC provides removal of material dropping out of the gas stream in the process coll section, and removal of material that has been deposited on the process coil and removed by the sootblowing process. The material from the process coil SSC is dropped into a chute rather than a clinker grinder. This chute directs process coll wastes to the Bottom Ash SSC providing a common removal point for bottom ash. process coil and pulverizer wastes. Provision is made for lateral movement of both SSCS to provide access to the boller for malntenance purposes.

The second ash removal system is that designed to handle flyash accumulated in the air heater hopper and the precipitator ash hoppers. This system pneumatically transports this ash to a common 2-undt storage silo. Vacuum blowers located downstream of the silo provides the motive force and removal from the hoppers is done under suction. The ash is separated from the air through the use of cyclone separators and a final filtering stage.

Removal of the stored flyash from the silo may be accomplished by openair or sealed means. A rotary ash conditioner is supplied for open-air remova1. This device wets the ash exiting the silo to reduce blowing during transport. A straight telescoping ash unloader is provided for sealed removal. This device extends to the removal container to eliminate blowing of ash during the transfer. 


\section{Inttial Start Up}

During the Initial start up of the EDS plant the fuels available for the hybrid boller will be the parent Illinols Midwest Bituminous coal and a high Btu fuel gas. During the plant start up, $35 \%$ of full load capacity can be achieved by firing the parent coal using three of the four pulverizers. Fuel gas makes up the additional $65 \%$ of full load required to reach full load. It is expected the EDS plant will be in infial start up for four to six months. After the start up period the hybrid boller will be capable of full load firing $100 \%$ vacuum bot toms without support fuel. A by-product high Btu gas will be available for ignition and warm up of the unit over the course of the plant life.

\section{General Performance}

Table 1: Fuel Analysis EDS Residue, Illinois Parent Coal

Table 2: Fuel Ash Analysis EDS Residue, Illinois Parent Coal

Table 3: General Design Conditions

Table 4: EDS Hybrid Boiler, Illinois Coal

-- EDS Residue Predicted Performance

Table 5: EDS Hybrid Boiler, Illinois Coal

-- EDS Residue, Circulation System Predicted Performance

Table 6: Partial List of C-E Coal Fired Units with Tubular Air Heaters and no Air Heater Sootblowing

Table 7: Comparison of Backpass Design Flue Gas Temperatures and Velocities for Coal Fired Units

Table 8: Full Load Process Coil Performance 
TABLE 1

FUEL ANALYSIS

EDS RESIDUE

ILLINOIS PARENT COAL

PARENT COAL

F.S RECEIVED DRY \& ASH FREE

16.30

34.74

39.76

9.20

Ash

TOTAL

U1 timate (\%wt)

$\begin{array}{lr}\text { Moisture } & 16.30 \\ \text { Hydrogen } & 4.08 \\ \text { Carbon } & 58.02 \\ \text { Sulfur } & 3.70 \\ \text { Nitrogen } & 1.11 \\ \text { Oxygen } & 7.52 \\ \text { Ash } & 9.20\end{array}$

TOTAL

HHV (Btu/lb)

Pyritic Sulfur (\%Wt)

Lb Ash $/ 10^{6}$ Btu

Grindability

Melting Temp. $\left({ }^{\circ} \mathrm{F}\right)$
53.5
LOW ASH RESIDUE

AS RECEIVED DRY \& ASH FREE

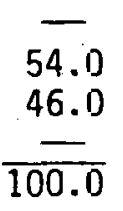

$\overline{5.6}$

85.0

3.0

1.7

4.7

$\frac{}{100.0}$

$\frac{14.5}{100.0}$

13,010

0.1

11.2

Greater than 100

$300^{\circ}-400^{\circ} \mathrm{F}$

11.2
HIGH ASH RESIDUE

AS RECEIVED DRY \& ASH FREE

$$
\begin{array}{r}
0.4 \\
39.7 \\
33.4 \\
26.5 \\
\hline 100.0
\end{array}
$$$$
54.3
$$$$
45.7
$$$$
\overline{100.0}
$$

0.4

$$
64.3
$$$$
2.2
$$

1.3

1.4

16.5

$\frac{10.5}{100.0}$

11,575

0.1

22.9

$$
\overline{5.3}
$$$$
88.0
$$$$
3.0
$$$$
1.8
$$$$
1.9
$$$$
\overline{100.0}
$$$$
15,840
$$

Greater than 100

$300^{\circ}-400^{\circ} \mathrm{F}$ 
TABLE 2

FUEL ASH ANALYSIS

EDS RESIDUE

ILLINOIS PARENT COAL

SAMPLE

Ash Fusibility (\%wt)

I.T. $\left({ }^{\circ} \mathrm{F}\right)$

S.T. $\left({ }^{\circ} \mathrm{F}\right)$

H.T. ( $\left.{ }^{\circ} \mathrm{F}\right)$

F.T. $\left({ }^{\circ} \mathrm{F}\right)$

Ash Composition (\%Wt)

$\mathrm{SiO}_{2}$

$\mathrm{Al}_{2} \mathrm{O}_{3}$

$\mathrm{Fe}_{2} \mathrm{O}_{3}$

$\mathrm{CaO}$

$\mathrm{MgO}$

$\mathrm{Na}_{2} \mathrm{O}$

$\mathrm{K}_{2} \mathrm{O}$

$\mathrm{TiO}_{2}$

$\mathrm{SO}_{3}$ TOTAL
LOW ASH

RESIDUE

2050

2090

2190

2350
HIGH ASH

RESIDUE

2080

2120

2230

2380
PARENT

COAL

2268

2346

2423

2508
49.0

15.7

18.8

4.9

0.8

1.1

1.5

1.0

$\frac{5.4}{98.2}$

11.2

0.41

3.80

3.13
51.5

17.0

15.7

4.6

1.2

1.2

1.6

0.9

5.8

99.5

22.9

0.35

3.46

3.03
8.71

0.43

4.25

48.71

17.31

19.34

4.55

0.97

1.35

2.49

0.86

3.18

98.76

2.81 
$\underline{\text { TABLE } 3}$

GENERAL DESIGN CONDITIONS

Number of Units:

Four (4)

S.team Capacity:

$487,200 \mathrm{lb} / \mathrm{hr}$

SHO Pressure:

1250 psig

SHO Temperature:

$925^{\circ} \mathrm{F}$

Feedwater Temperature:

$250^{\circ} \mathrm{F}$

Process fluid Flow:

$2,170,000 \mathrm{lb} / \mathrm{hr}$

Process Fluid Pressure:

2500 psig

Process Fluid Outlet Temperature:

$840^{\circ} \mathrm{F}$

Process Fluid Inlet Temperature:

$413^{\circ} \mathrm{F}$

Process Coil Heat Absorption Rate:

$600 \mathrm{MBtu} / \mathrm{hr}$

Steam/Process Fluid Heat Duty Ratio:

$50 \% / 50 \%$

Sulfur Removal:

$90 \%$

Particulate In Flue Gas:

$0.03 \mathrm{Ibs} / \mathrm{MBtu}$ Fired

NOx In Flue Gas:

$0.6 \mathrm{lbs} / \mathrm{MBtu}$ Fired

Vacuum Bottoms Surface Moisture:

$2 \%$ by weight

Unit Turndown:

$50 \%$ while maintaining $840^{\circ} \mathrm{F}$ process coil outl et temperature 
Table 4

EDS Hybrid Boiler

Illinois Coal - EDS Residue

Predicted Performance

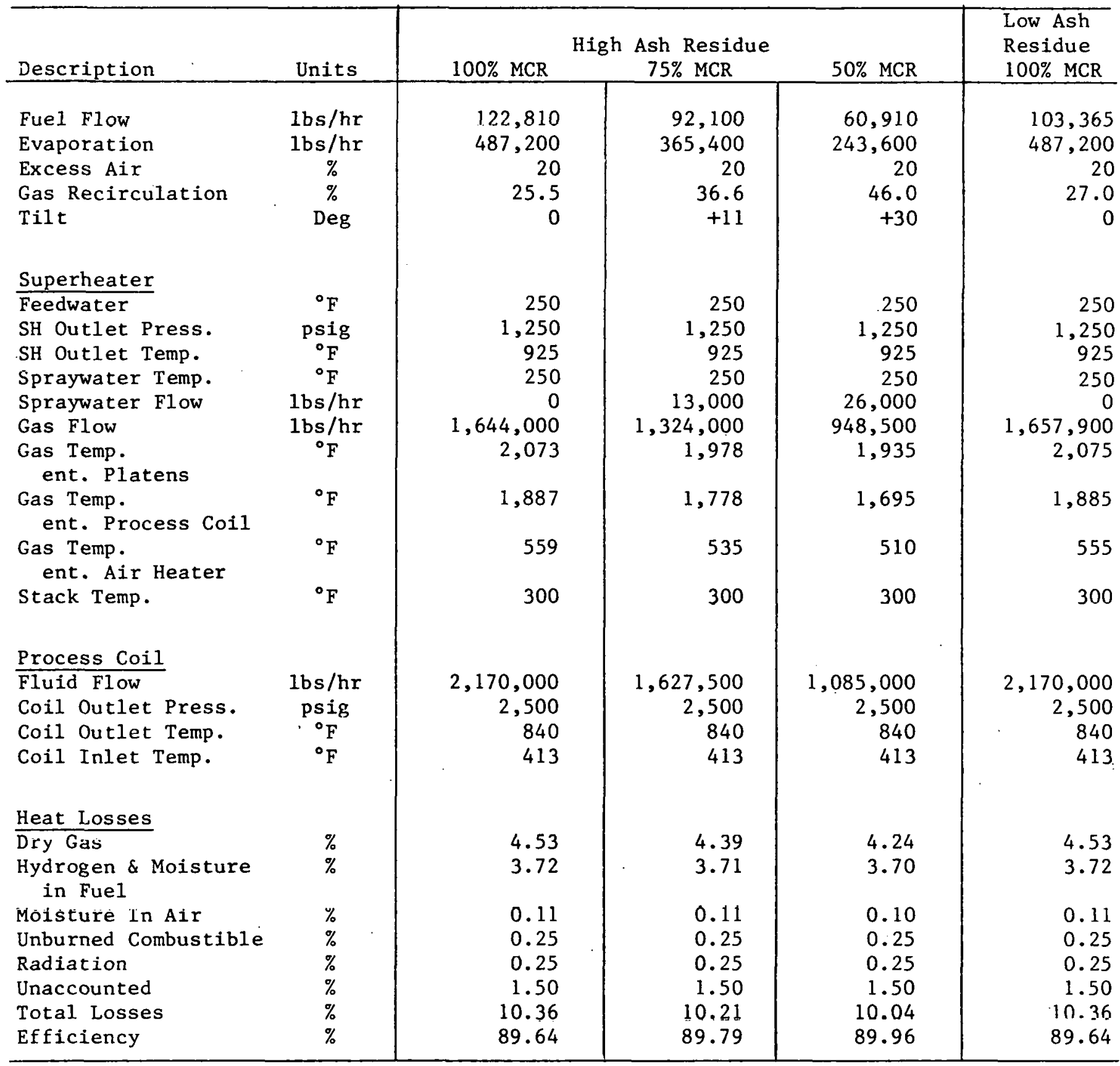


TABLE 5

\author{
EDS HYBRID BOILER \\ ILLINOIS COAL-EDS RESIDUE \\ CIRCULATION SYSTEM \\ PREDICTED PERFORMANCE
}

FIRING RATE: MCR 487,200 LBS/HR EVAPORATION

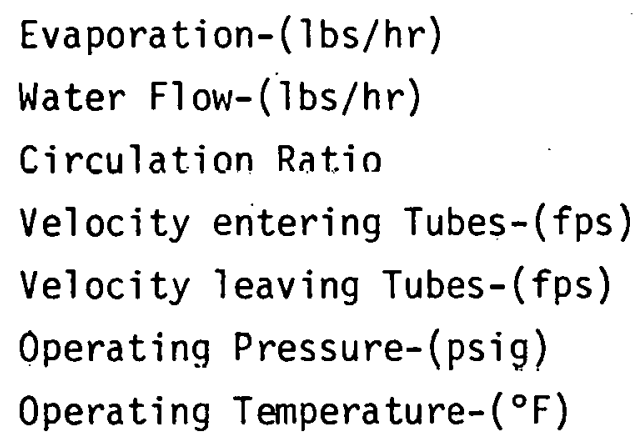

$\begin{array}{rrr}\text { Front Wall } & \text { Rear Wall } & \text { Side Walls (Total) } \\ 135,470 & 92,800 & 259,700 \\ 1,625,700 & 1,252,500 & 3,377,300 \\ 12 & 14 & 13 \\ 3.70 & 2.85 & 3.60 \\ 7.45 & 5.40 & 7.00 \\ 1,375 & 1,375 & 1,375 \\ 587 & 587 & 587 \\ 43.35 & 43.35 & 43.35 \\ 21.61 & 22.88 & 22.48 \\ 29.99 & 30.96 & 30.67\end{array}$

FIRING RATE: $50 \%$ MCR 243,600 LBS/HR EVAPORATION

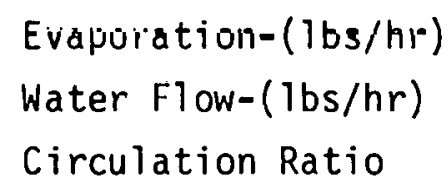

Front Wal

69,10

$1,433,905$

21

$$
3.26
$$

5.27

1,375

587

43.59

26.96

33.95 $\frac{\text { Rear Wall }}{47,745}$

$$
1,098,129
$$

23

2.49

3.88

1,375

587

43.59

28.01

34.66
Side Walls (Total) $1 ? 6$, กกศ

$2.797,201$

22

3.11

4.96

$1,37.5$

587

43.59

27.61

34.39 
TABLE 6

\begin{abstract}
PARTIAL LIST OF C-E COAL FIRED UNITS WITH TUBULAR AIR HEATERS AND NO AIR HEATER SOOTBLOWING
\end{abstract}

FUEL

Unit 1

High Volatile Bituminous

Unit 2

Mid-West Bituminous

Eastern Bituminous

Semi-Bituminous

Bituminous

Unit 6

Bituminous
EVAPORATION

$275,000 \mathrm{lbs} / \mathrm{hr}$

$400,000 \mathrm{lbs} / \mathrm{hr}$

$350,000 \mathrm{lbs} / \mathrm{hr}$

$208,000 \mathrm{lbs} / \mathrm{hr}$

$500,000 \mathrm{lbs} / \mathrm{hr}$

$600,000 \mathrm{lbs} / \mathrm{hr}$ 


\section{TABLE ? \\ COMPARISON OF BACKPASS}

DESIGN FLUE GAS TEMPERATURES AND VELOCITIES

FOR

TYPICAL C-E COAL IIRED UNITS

\begin{tabular}{|c|c|c|c|c|c|c|c|c|c|}
\hline $\begin{array}{c}\text { Unit } 1 \\
3,580,000 \mathrm{ib} / \mathrm{hr} \text { Evap. } \\
500 \mathrm{WW} \\
\text { Eastern Bit. }\end{array}$ & - & $\frac{1724^{\circ} \mathrm{F}}{58.7 \mathrm{fps}}$ & $\frac{1585^{\circ} \mathrm{F}}{50.3 \mathrm{fps}}$ & - & $\frac{1416^{\circ} \mathrm{F}}{43.1 \mathrm{fps}}$ & $\frac{1327^{\circ} \mathrm{F}}{48.5 \mathrm{fps}}$ & - & $\frac{1148^{\circ} \mathrm{F}}{56.1 \mathrm{fps}}$ & $\frac{849^{\circ} \mathrm{F}}{55.2 \mathrm{fps}}$ \\
\hline $\begin{array}{c}\text { Unit } 2 \\
4,220,000 \mathrm{jb} / \mathrm{hr} \text { Evap. } \\
600 \mathrm{WW} \\
\text { Midwest Bit. }\end{array}$ & $\frac{1832^{\circ} \mathrm{F}}{71.0 \mathrm{fps}}$ & $\frac{1704^{\circ} \mathrm{F}}{67.9 \mathrm{fps}}$ & - & - & $\frac{1430^{\circ} \mathrm{F}}{64.5 \mathrm{fps}}$ & - & $\frac{1243^{\circ} \mathrm{F}}{65.2 \mathrm{fps}}$ & - & - \\
\hline $\begin{array}{c}\text { Unit } 3 \\
3,800,0001 \mathrm{~b} / \mathrm{hr} \text { Evap. } \\
520 \mathrm{MW} \\
\text { Sub. Bit. }\end{array}$ & $\frac{1794^{\circ} \mathrm{F}}{44.5 \mathrm{fps}}$ & $\frac{1772^{\circ} \mathrm{F}}{66.4 \mathrm{fps}}$ & $\frac{1658^{\circ} \mathrm{F}}{62.2 \mathrm{fps}}$ & $\frac{1509^{\circ} \mathrm{F}}{58.7 \mathrm{fps}}$ & - & - & $\frac{1242^{\circ} \mathrm{F}}{65.2 \mathrm{fps}}$ & - & - \\
\hline $\begin{array}{c}\text { Unit } 4 \\
4,150,000 \mathrm{ib} / \mathrm{hr} \text { Evap. } \\
560 \mathrm{MW} \\
\text { Midwest Bit. }\end{array}$ & $\frac{1794^{\mathrm{C} F}}{68.8 \mathrm{fps}}$ & $\frac{1671^{\circ} \mathrm{F}}{66.4 \mathrm{fps}}$ & - & $\frac{1525^{\circ} \mathrm{F}}{68.0 \mathrm{fps}}$ & $\frac{1404^{\circ} \mathrm{F}}{62.9^{\mathrm{fps}}}$ & - & $\frac{1184^{\circ} \mathrm{F}}{55.1 \mathrm{fps}}$ & - & - \\
\hline $\begin{array}{l}\text { EDS Hybrid Boiler } \\
\text { IIl inois EDS High } \\
\text { Ash Vacuum Bottoms }\end{array}$ & $\frac{1887^{C} F}{28.4 f p s}$ & - & - & - & $\frac{1376^{\circ} \mathrm{F}}{39.4 \mathrm{fps}}$ & - & - & - & $\frac{1018^{\circ} \mathrm{F}}{2 y .7 \mathrm{fps}}$ \\
\hline
\end{tabular}


PROCESS COIL SECTION

\begin{tabular}{|c|c|c|c|}
\hline$S_{t} / D_{0}\left(D_{0}=4.5^{\prime \prime}\right)$ & 1.667 & 3.33 & 1.667 \\
\hline$S_{1} / D_{0}\left(D_{0}=4.5^{\prime \prime}\right)$ & 2.0 & 2.0 & 2.0 \\
\hline$T_{G}($ in/out $)\left({ }^{\circ} \mathrm{F}\right)$ (Gas) & $1018 / 560$ & $1887 / 1376$ & $1376 / 1018$ \\
\hline $\mathrm{T}_{\mathrm{F}}$ (in/out) $\left({ }^{\circ} \mathrm{F}\right)$ (Process Fluid) & $413 / 540$ & $540 / 722$ & $722 / 840$ \\
\hline $\mathrm{T}_{\mathrm{g}}\left({ }^{\circ} \mathrm{F}\right)$ (Avg. Gas Temp.) & 789 & 1631 & 1197 \\
\hline$T_{f}\left({ }^{\circ} \mathrm{F}\right)$ (Avg. Fluid Temp.) & 476 & 631 & 781 \\
\hline LMTD & 279 & 990 & 356 \\
\hline $\mathrm{R}_{\mathrm{T}}$ (Overal1 Heat Transfer Rate) ${ }^{(1)}$ & 6.72 & 8.95 & 8.73 \\
\hline Material & 304 SS & 304 SS & 304 SS \\
\hline Conductivity - K (But-in/hr-ft $\left.{ }^{2}{ }^{\circ} \mathrm{F}\right)$ & 138 & 147 & 143 \\
\hline Process Fluid Coefficient $\left(h_{i}\right)$ & 244 & 275 & 225 \\
\hline$D_{0} / D_{i}$ & 1.45 & 1.45 & 1.45 \\
\hline $\begin{array}{l}\text { Process Coil Absorption Rate } \\
\left(\text { Btu/hr/ft }{ }^{2}\right)^{2}\end{array}$ & 2720 & 12,850 & 4506 \\
\hline
\end{tabular}

(1) The coil thickness used for the overall transfer rate calculation was fixed at the design point and used for the entire coil. Actual coil thicknesses will vary throughout its length.

(2) Absorption Rate in reference to the Inside Tube Surface. 


\section{Process Coil}

The process coil is the heat exchanger through which the process flutd is preheated for the EDS process. Design guidelines for the process coil were provided by ER\&E based on the operating experience of the EDS Coal Liquefaction Pilot Plant (ECLP) in Baytown, Texas. process coil arrangement can be seen on the hybrid boiler general arrangement drawing.

PROCESS COIL DESIGN CONDITIONS

o Heat duty: $600 \mathrm{MBtu} / \mathrm{hr}$

Process fluid flow rate: $2,170,000 \mathrm{lbs} / \mathrm{hr}$

Inlet temp: $413^{\circ} \mathrm{F}$, Outlet temp: $840^{\circ} \mathrm{F}$

Pressure: 2500 psig

- $50 / 50$ process/steam heat duty ratio

- Tube outside diameter: 4-1/2 in.

- $50 \%$ turndown

o Linear velocity of process fluid: 9 to $18 \mathrm{ft} / \mathrm{sec}$.

- $\pm 5^{\circ} \mathrm{F}$ process outlet temperature

- Maximum film temperature: $900^{\circ} \mathrm{F}$

- $1300^{\circ} \mathrm{F}$ steam temp. during decoking

- Inside film coefficient: See Figure 11

- Maximum heat transfer rates as a function of the process fluid temp: See Figure 12

\section{SURFACE CONFIGURATION}

Conventional utility steam generators utilize surface arrangements combining both vertical and horizontal configurations. The factors which Influence the selection of one versus the other are: 
- Fuel properties

o Economics

o Compactness of the design

- Minimizing of the botler island plan area

A vertical surface configuration was specified for the process coll in order to prevent stratification of the process fluid and facilitate tube surface removal for maintenance purposes. The process fluid (a three phase mixture) is more easily separated in horizontal then vertical tubes. Long horizontal circults would tend to cause seperation of phases due to density differences, and hence, localized overheating according to the thermal properties of each phase.

The selection of a vertical surface configuration also facilitates maintenance of the process coil. Platen sections or individual tube removal can be accomplished easily through the hopper opening under the process coll. The submerged scraper conveyor can be rolled to one side allowing access to the entire process coll area. The necessary hoist capacity has been included to allow Individual coll loop sections to be easily handled during maintenance operations.

\section{HEAT TRANSFER RATE PREDICTION}

C-E heat transfer standards were used in the design of the process co11. The process coll is substantially different from the superheater and reheater surface installed in the convection pass of a. conventional steam generator. The tube $O D$, tube thickness, and ineide film coefficient (Figure 11) all affect heat transfer. The C-E heat transfer standards were compared over a wide range of tube sizes and flow rates with several other heat transfer standards and were found to be in agreement. 


\section{DESIGN CONSIDERATIONS}

The destgn conditions and the predicted heat transfer rates have been previously specified. The following defines how the design conditions were applied to the design of the process coil.

The fouling characteristics of the vacuum bottoms and current coal firing practices determined the transverse spacing of the process coil. The C-E laboratory test result indicate a rapid initial ash buildup but deposit buildup does not occur due to the low bonding strength of the deposits. The flue gas erodes any subsequent ash deposition. The laboratory test results also indicate the ash deposits become sticky as they approach the vacuum bottoms ash initial deformation temperature of $2080^{\circ}$. Deposits in the ash fusion temperature zone tend to build up between sootblowing cycles. A transverse spacing ${ }^{1}$ of 15-1/2 inches has been specified for the process coll for flue gas temperatures greater than $1500^{\circ} \mathrm{F}$.

Once the transverse spacing has been determined the optimum element height for the process coil is determined by maintaining a maximum velocity of $45 \mathrm{fps}$ in the process coll to minimize the potential for flyash erosion with a high ash fuel and to maintaln acceptable convective heat transfer. Table 7 compares flue gas velocities for several coal fired units.

The average fluid velocity in the process coll is $18 \mathrm{fps}$ at full load and approximately $9 \mathrm{fps}$ at half load. By maintaining the process coil

15 inch transverse corresponds to a 10-1/2 inch clear; 7-1/2 inch transverse, 3 inch clear. 
fluid velocity below 18 fps, internal tube erosion will be minimized and fluid side pressure drop minimized.

To limit coking in the process coll, a constraint on heat transfer rates were specified by ER\&E as shown on Figure 11. As previously discussed, C-E heat transfer standards were used in the design of the process coil.

The longitudinal (depth) spacing of the process coll was dictated by the bending requirements. If the radius of bend curvature is too small, it is difficult to produce a uniform bend with a large diameter heavy wall tube. With this constraint the depth spacing was kept to a minimum of two times the tube outer diameter which is nine inches. The cavity width for the sootblowers is two feet, which is a standard for coal firing.

PROCESS COIL PERFORMANCE AND PHYSICAL DESIGN

A three section process colj. comprised of 48 individual tube. circults with an average circuit length of $3400 \mathrm{ft}$. was selected to satisfy the prevlously discussed constraints and condtions. Two counterflow and a parallel flow sections were specifled as shown on Figure 16 .

\section{SECTION I (Low Temperature Section)}

The low temperature section is located downstream of Section III

the low temperature section, and upstream of the primary

airheater. It consists of 48 single tube assemblies with a transverse spacing between assemblies of 7.5 inches (for more detalls refer to the equipment specifications). A counterflow configuration is used with the process fluid entering the section 
at $413^{\circ} \mathrm{F}$ and leaving at $540^{\circ} \mathrm{F}$. The flue gas enters the section at $1018^{\circ} \mathrm{F}$ and leaves at $560^{\circ} \mathrm{F}$.

SECTION II (Intermediate Temperature Section)

The intermediate section is located downstream of the finishing superheater section and waterwall screen and upstream of Section III. It consists of 24 double tube assemblies with a transverse spacing between assemblies of 15 inches (for more details refer to the equipment specification). A counter flow configuration is used. with the process fluid entering the section at $540^{\circ} \mathrm{F}$ and leaving at $722^{\circ} \mathrm{F}$. The flue gas enters the section at $1887^{\circ} \mathrm{F}$ and leaves at $1376^{\circ} \mathrm{F}$.

\section{SECTION III (High Temperature Section)}

The high temperature section is located downstream of Section II and upstream of section I. It consists of 48 single tube assemblies with a transverse spacing between assemblles of 7.5 inches (for more details refer to the equipment specifications). A parallel flow configuration is used with the process fluid entering the section at $722^{\circ} \mathrm{F}$ and leaving at $840^{\circ} \mathrm{F}$. The flue gas enters the section at $1376^{\circ} \mathrm{F}$ and leaves at $1018^{\circ} \mathrm{F}$. Section III is the most important section with respect to the absorption rate limitations, see Fig. 15. The design absorption rates are 7,700 Btu/hr-sq.ft. at the inlet of the section, where the fluid temperature is $722^{\circ} \mathrm{F}$, and $2100 \mathrm{Btu} / \mathrm{hr}-\mathrm{sq} . \mathrm{ft}$. at the outlet $\left(840^{\circ} \mathrm{F}\right)$.

\section{FLOW UNBALANCE AND GAS BYPASSING}

The process coll will be subjected to some uneven flue gas distribution across the width of the unit. A typical mass flow and temperature 
profile at the coil entrance can be seen on Figure 7 . The unbalance w11 decrease rapidly due to the resistance effects of the coll. Gas unbalance orginates from the turbulence created in the firing system and during gas turns.

By placing several waterwall screen tube sections upstream of the process coil, the gas unbalance generated in the furnace is dampened to acceptable levels. The mass flow and temperature profiles entering the process coll result in relatively constant gas flows and temperature across the width of the coll section. Since the process fluid in each tube will be controlled independently, any unbalance of the process flutd temperature can be adjusted by regulating flow of the process fluid to each individual element.

Gas bypassing is also possible through the bottom of the coll and the submerged scraper conveyor hopper. In order to minimize the bypassing, a baffle is located in the hopper. The cold flow modeling of the Hybrid Boiler (to be performed during the Summer of 1982) is expected to give valuable information with regard to both flow unbalance and gas bypassing. The results of the modeling will help in defining the number and location of the baffles which minimizes flow unbalance and gas bypassing.

PROCESS COIL ROOF TUBE SUPPORT

Durfing the course of the hybrid boller destgn, the support mechanism for the process coil was analyzed with several design configurations discussed hetween r.F. and ER\&E. The objective of the design was to arrange the support system in such a manner as to reduce the number of roof penetrations while providing for tube expansion of both the process $\operatorname{col} 1$ and steam cooled encasement. Other constraints included 
dissimilar welds, erosion of support ties and exposure to $1900^{\circ} \mathrm{F}$ flue gases.

The support system for the process coil can be seen on the attached drawing. A stainless steel hanger rod is welded to the top of each process coil 1oop. A tube lined with insulation is fitted over the supporting hanger rod to provide protection from erosion and temperature. The support (hanger) rod passes up through the steam cooled roof tubes and is bolted to a steel channel beam which runs from front to rear of the process coil. The channel beam is also used to support the steam cooled roof tubes. Clips are welded to each of the roof tuhes and are free to slide on a bar welded to the channel, allowing room for roof tube expansion. The channel beams are supported with hangers connected to the unit support steel.

Using the support method described, dissimilar welds between supporting members is eliminated. The stainless steel hanger rods attached to the coll are thermally protected allowing the process coil and roof to cool the rod. Moof penetrations have leèu minfulzed seduclug the area prone to flue gas leakage. The coll penetrates the roof only to enter or exit the heat transfer area. Coil expansion characteristics along its length are markedly different from the roof tubes. This arrangement provides for the coll and roof tubes to be commonly supported yet allowed to expand independent of each other. The process coil will be tied to adjacent tubes along its helght by using flex and slip spacers. These devices allow for vertical movement due to expansion, but prevent front to rear and side to side sway of the tubes. 
The primary means of process fluid coll outlet temperature control is the firing rate. Increasing the firing rate and matntaining a constant process fluid flow will increase the process fluid coll outlet temperature. Conversely, decreasing the firing rate will decrease the process fluid coil outlet temperature.

The two other means of varying the heat absorbed by the process coil are gas recirculation and windbox tilt. A discussion on the effect of gas recirculation and windbox tilt may be found in Section $C$, Design Considerations.

During the design phase the topics of potential tube leaks and considerations for cofl replacement were discussed. A tubular air preheater was selected to eliminate the contact of the flammable process fluid and combustion air in the event of a process coil tube leak. Preliminary discussions regarding leak detection equipment and operating considerations in this mode were discussed with the final recommendations deferred until more detailed study can be made during the 1982 Phase II program.

\section{DECOKING}

Coke formation on the inside of the process coll tubes insulates the process fluid heat transfer from the fluid and tube wall. This in turn ralses the tube wall metal temperature. When the tube wall metal temperature approaches its design value the unit is shutdown and decoked. The hybrid boller has been designed to allow decoking. The design takes into consideration the expansion and temperature profiles that will exist during this operation. 
The decoking process involves two phases, spalling and burning. During the spalling phase the coll will be subjected to a $1350^{\circ} \mathrm{F}$ maximum metal temperature. Nitrogen followed by steam will be used to spall. the coke. The steam used in spalling at $353^{\circ} \mathrm{F}, 125$ psig will be Introduced at the low temperature section tube inlet and rise up to $1300^{\circ} \mathrm{F}$ at the outlet. Due to the arrangement of the coil, the steam w111 approach $1300^{\circ} \mathrm{F}$ at the end of the low temperature section of the co11. The steam will be close to $1300^{\circ} \mathrm{F}$ throughout the intermediate and high temperature sections. The flue gas entering the coil will be approximately $1320^{\circ} \mathrm{F}$ and leave at $840^{\circ} \mathrm{F}$. There will be essentially no heat transfer through the process coll intermediate and high temperature sections except for a smail amount of heat absorbed in the steam cooled walls of the process coil encasement. Effectively, all the heat is absorbed by the process coil during decoking is absorbed by the low temperature section. This unusual absorption profile is due to the ratio of flue gas to decoking steam and to the extensive coil surface. The process coll arrangement exposes the high temperature section, that is susceptible to coking, to $1300^{\circ} \mathrm{F}$ steam and more effective spalling.

During the burning phase air is introduced at the low temperature section tube inlet and will rise to $1300^{\circ} \mathrm{F}$ at the high temperature tube outlet. Due to the possibility of localized overheating as a result of the burning process coil, metal temperatures must be carefully monitored.

Gas recirculation is used to temper the flue gas to the process coll. Control of the decoking steam temperature will be achieved by controlling firing rate and can be tempered using a combination of 
windbox tilt to control the furnace outlet gas temperature and gas recirculation as in normal operation. 


\section{E. Avallability Analysis}

The work performed during this design study was primarily concerned with investigating the practicality of applying C-E's knowledge of equipment component failure and its affect on availability to: develop predicted Hybrid Boiler System availability, determine potential areas of avallability reduction and to analyze mean time between failure, and analyze mean time to repair major system components.

In general terms, equipment availability may be considered as that fraction of time that a system or components is capable of operation. Moreover, if the assumption is made that most steam generators in the C-E data program, because of their size, are either on line or being repaired and little time is spent on standby, then avallability, exclusive of scheduled outages, could be defined as:

\section{Ava1lability $=$}

Forced Outage Rate can also be defined in terms of equipment availability ae:

Forced Outage Rate $=$

$\mathrm{C}-\mathrm{E}$ has determined that the components causing most of the outages and load reductions can be classifled into the following nine ma jor components categories for the Hybrid Boiler.

I Waterwa1ls

II Superheater/Convective Process Coil

III Tubular Alr Preheater

IV Sootblowers/Submerged Scraper Conveyor

V Controls 
VI Fans

VII Pulverizers

VIII Precipitators $/ \mathrm{SO}_{2}$ Scrubbers

A preliminary evaluation of the Hybrid Boller forced outage rate was made based on avallability records of utility boilers in the 400 to 600

MW range. Based on this data, C-E predicts a forced outage rate of 8

to $10 \%$ is possible for the Hybrid Boller based on good operating and maintenance procedures. 


\section{F. Cost Estimate}

Scope of Equipment

Boiler Island

Four (4) Radiant Pulverized Coal/EDS

Vacuum Bottoms Fired Units - Each unit consisting of:

Boiler and its Appurtances incl. Non-Return Valves

Fusion Welded Waterwall

Superheater \& Desuperheater

Steam Cooled Back Pass

Tilting Tangential Windboxes

Four (4) Coal/EDS Bottoms Silos

Four (4) C-E Bowl Mills/Unit - complete with C-E Feeders

Solid State Burner Controls (FSSS)

Air Ductwork from F.D. Fan to Burner and Mills

Gas Duct to Tubular Air Heater Outlet

Gas Recirculation Duct to Furnace

Secondary Tubular Air Heater and Steam Coil Air Heater

Buckstays \& Misc. Casing

Setting and Insulation and Lagging

Dual Primary Air Fans complete with Motors

Dual Forced Draft Fan complete with Motors

Dual Induced Draft Fans complete with Motors

Complete Sootblower System with Pipings, Valves and Fittings

Structural steel for Boiler and its Auxiliaries with Platforms, Walkways and Ladders

Process Coil - Fabricated with. SA-213 TP 304 Material

One (1) Common Stack for four units including Dampers

Instruction Manuals

Erection and Service Representative

Freight in T11innis

\section{Precipitators}

Four (4) Rigid Frame Electrostatic Precipitators - Each unit consisting of:

Precipitators, Flange to Flange

Transitions

Access

Support Steel 
Insulation and Lagging (material only)

Instruction Manuals

Gas Flow Model Study

Erection Representative

Service Representative

Freight

(Foundations and Buildings not included)

Flue Gas Desulfurization Island

Six (6) Wet Flue Gas Scrubbers Modules - Each unit consisting of:

Absorber System

Additive System

Flue Gas Reheater System

Auxiliary Equipment

Electrical Equipment

Instruction Manuals

Training Program

Design Model

Gas Flow Model Study

Erection Representative

Service Representative

Freight

(Foundations and Buildings not included)

\section{Pricing}

Four (4) Hybrid Boilers

\& Auxiliary Equipment

Four (4) Process Colls

\& Support (excluding

Steam Cooled Enclosure)

Total Boiler Island

Four (4) Precipitators

Wet Flue Gas

Desulfurization Systems

for four (4) Hybrid

Boilers

Total Flue Gas Cleanup
$\$ 75,075,000$

$\$ 113,075,000$

$\$ 82,225,000$

$\$ 99,225,000$

$\$ 157,300,000$

$\$ 212,300,000$

\$. $13,840,000$

$\$ 23,428,000$

$\$ 18,380,000$

$\$ 26,572,000$

$\$ 32,220,000$

$\$ 50,000,000$ 
G. Equipment Specifications

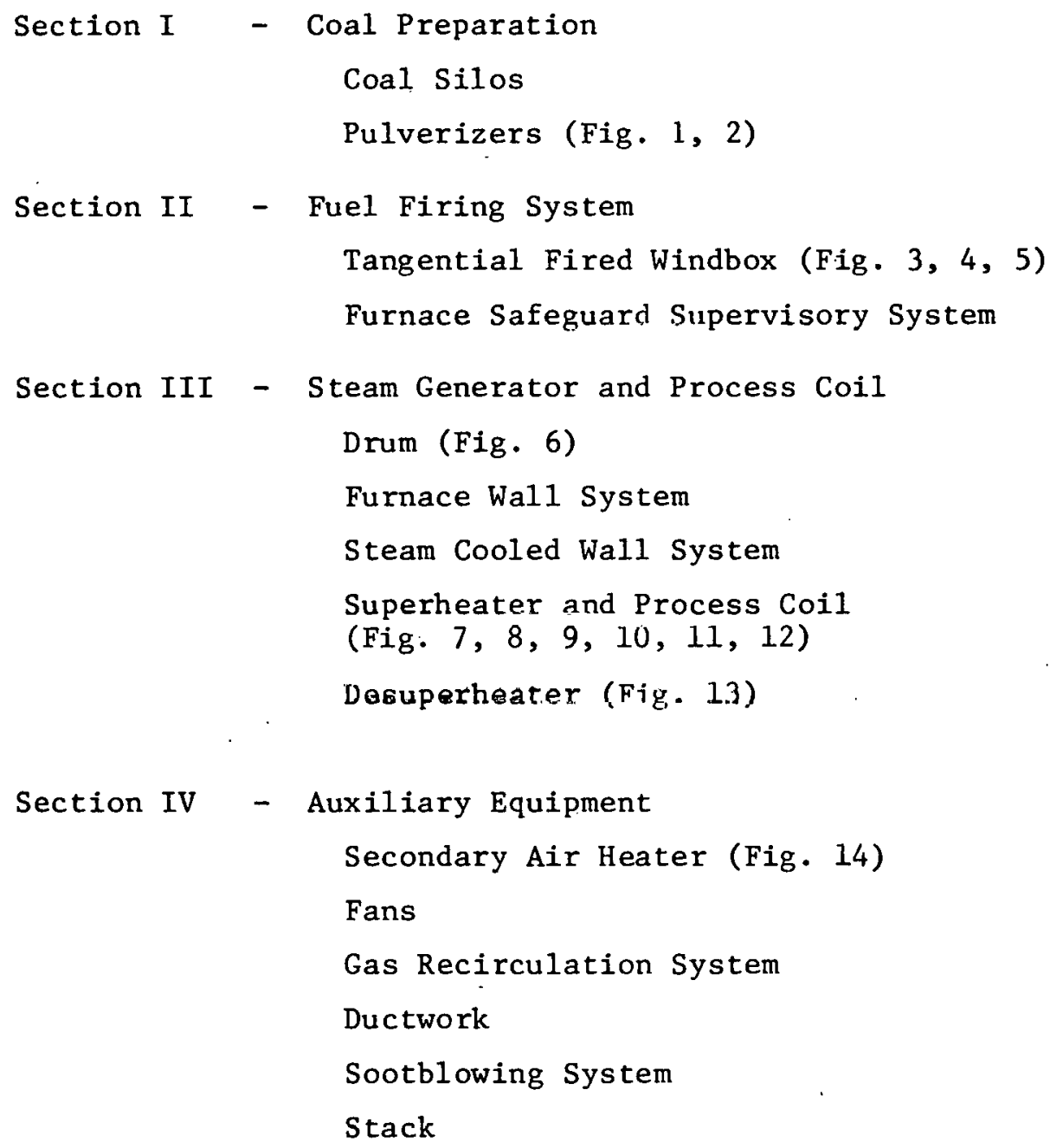


SECTIONI-COAL PREPARATION 


\section{COAL SILOS}

Number of Silos: 4

Height: $\quad 74 \mathrm{ft}$.

Diameter: $\quad 16 \mathrm{ft}$.

$78^{\circ}$ Hopper with a $2 \mathrm{ft}$. opening

Capacity: $\quad 10,600 \mathrm{ft}^{3}$

Diverter Valve

Manually operated knife-gate

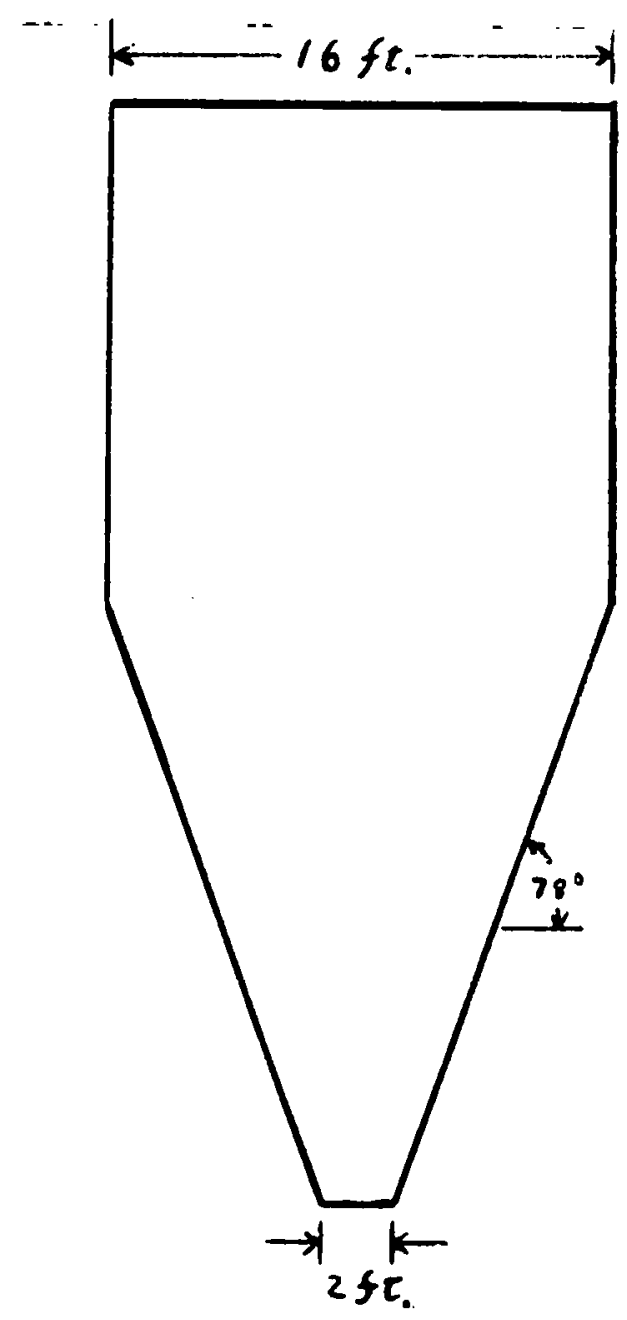




\section{PULVERIZERS}

\begin{tabular}{|c|c|c|c|c|c|}
\hline Number & Type & Size & & Max. Capacity & Manufacturer \\
\hline 4 & $\mathrm{RP}$ & 623 & 52,500 & 1bs/hr Vacuum Bottoms & C-E Inc. \\
\hline
\end{tabular}

Included also in the pulverizing system are:

Integral volumetric Feeder

Pulverizer motor rated at $200 \mathrm{hp}$

Lube $0 i 1$ system

Seal air system

Spring loaded journal assembly

Steam inerting and fire detection system

Each pulverizer feeds one elevation of burners and it is capable of grinding either coal or vacuum bottoms. Full load is attained by firing vacuum bottoms with three of the four pulverizers in service. The ability of the pulverizers to fire the parent coal is 1 imited by the air heaters capacity.

\section{Predicted Mil1 Performance}

\begin{tabular}{|l|r|r|r|}
\hline $\begin{array}{c}57 \% \text { Load } \\
\text { Coal Firing }\end{array}$ & $\begin{array}{r}3 \text { of } 4 \\
\text { Mi11s in Service }\end{array}$ & $24,1031 \mathrm{bs} / \mathrm{hr}-\mathrm{mi} 11$ & $110 \mathrm{kw} / \mathrm{mi11}$ \\
\hline $\begin{array}{c}100 \% \text { Load } \\
\text { Vacuum Bottom } \\
\text { Firing }\end{array}$ & $\begin{array}{c}3 \text { of } 4 \\
\text { Mi11s in Service }\end{array}$ & $40,9361 \mathrm{bs} / \mathrm{hr}-\mathrm{mi11}$ & $132 \mathrm{kw} / \mathrm{mi11}$ \\
\hline
\end{tabular}


FIGURE 1

\section{C-E PULVERIZER TYPE RP}

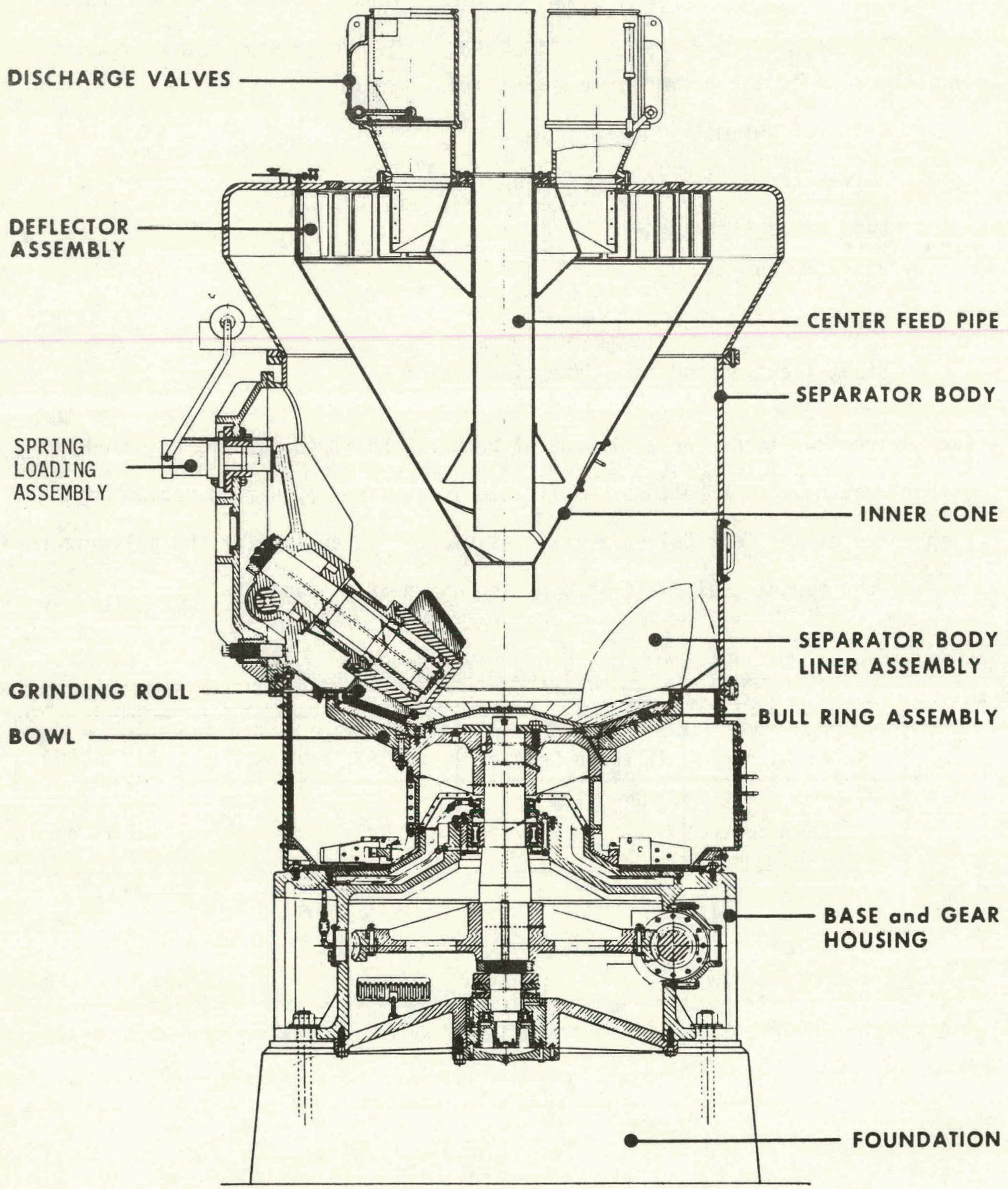




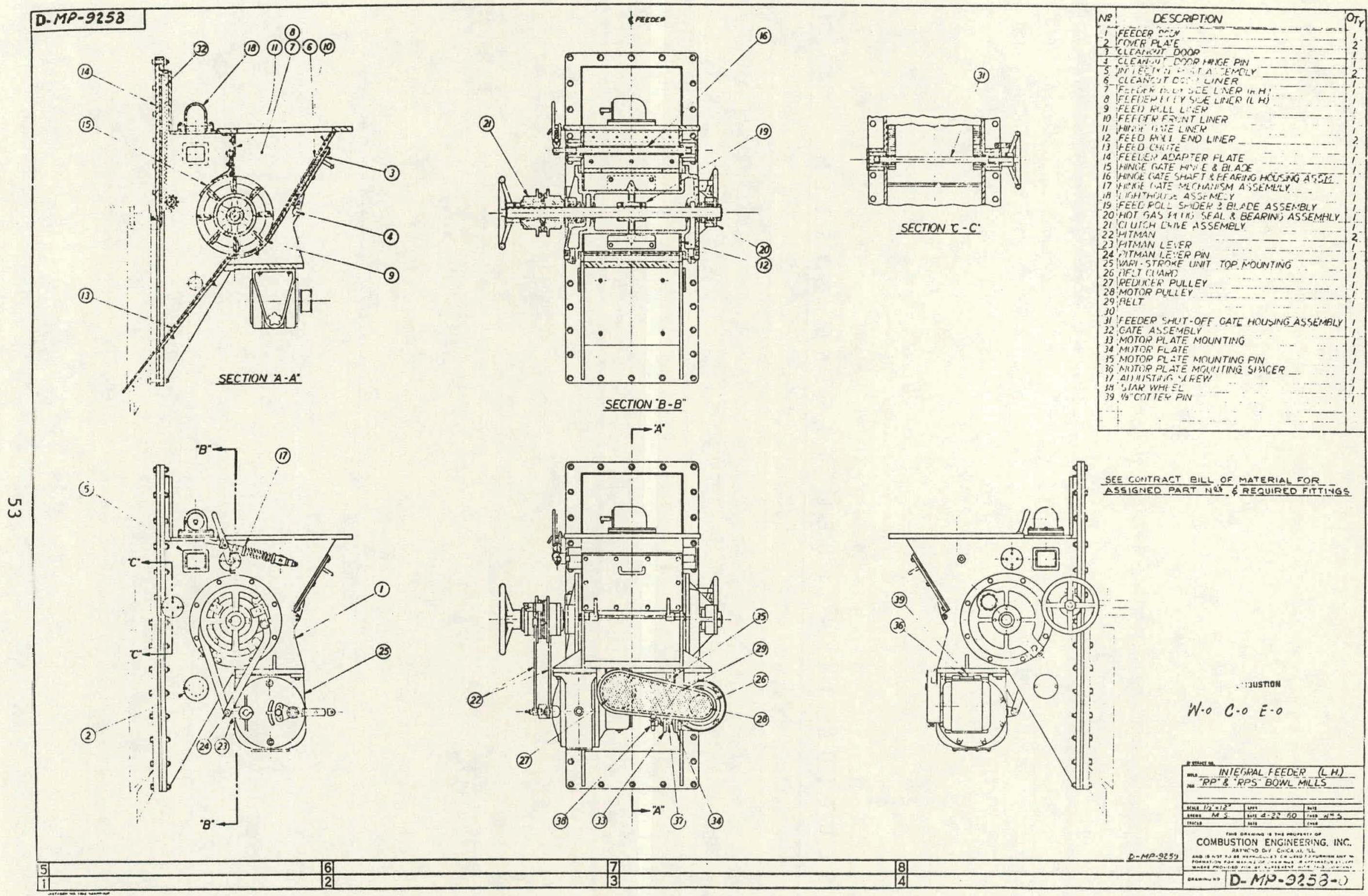


SECTIONII-FUEL FIRING SYSTEM 
Four (4) 18" windbox assemblies located in each corner of the furnace consisting of fuel and air compartments arranged vertically, complete with necessary insulation, ignitors, flame scanners, dampers and fuel connections, all shop assembled.

Four (4) water cooled, tilting fuel compartments per windbox assembly, capable of firing either coal or vacuum bottoms.

Tivo (2) IFM gas ignitors per windbox assembly

Three (3) Fireball Flame Scanners

Two (2) Elevations of High Btu Gas Compartments

Two (2) Compartments of Overfire Air per windbox assembiy

Fuel Pipe (from pulverizer to windbox): 12.75" OD with 0.375 in. thickness 


\section{C-E TANGENTIAL WINDBOX}

FIGURE 3

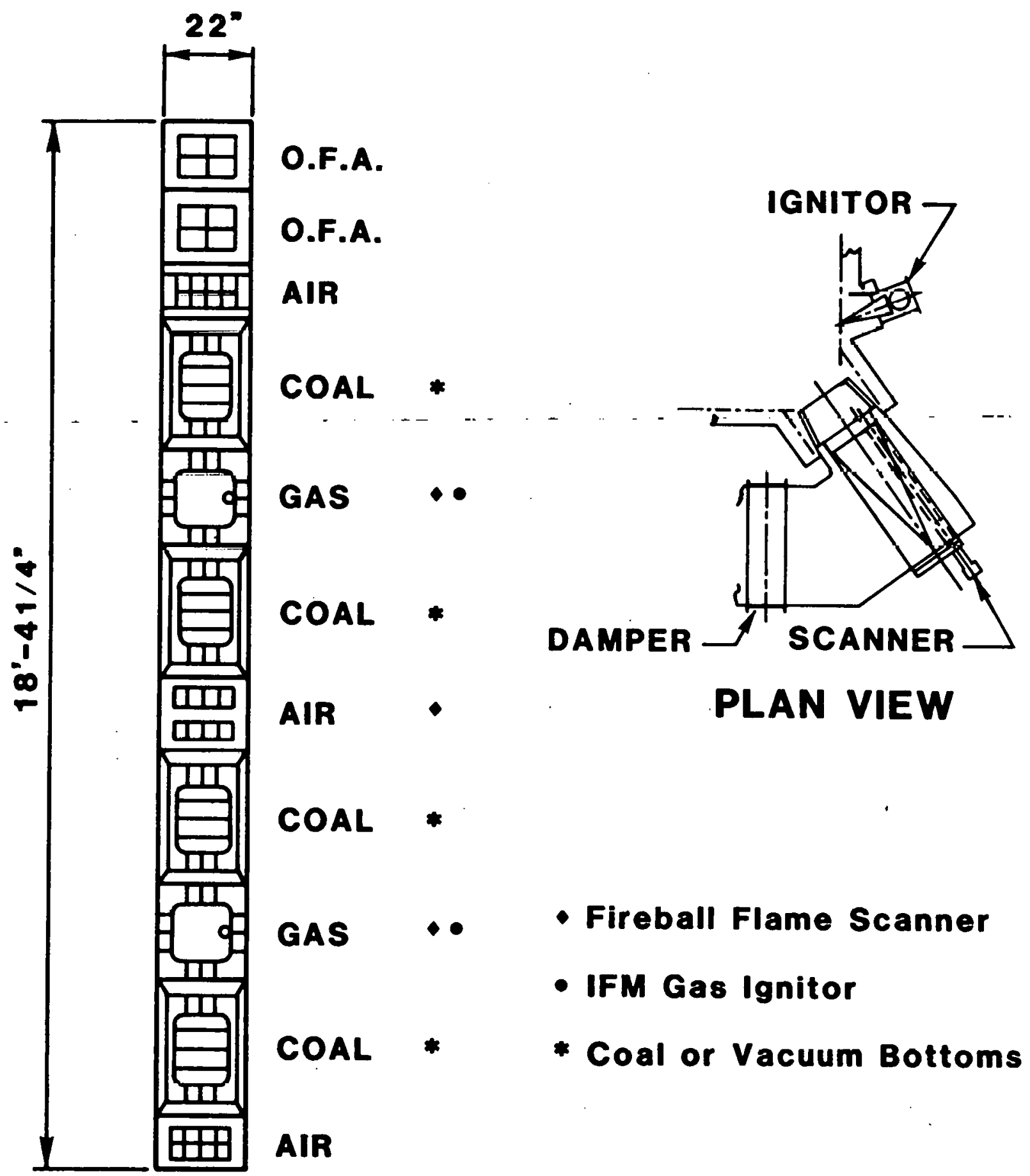

EXXON HYBRID BOILER

ILLINOIS COAL WINDBOX ASSEMBLY 
FIGURE 4

TYPICAL

\section{C-E TANGENTIAL FIRING WINDBOX}

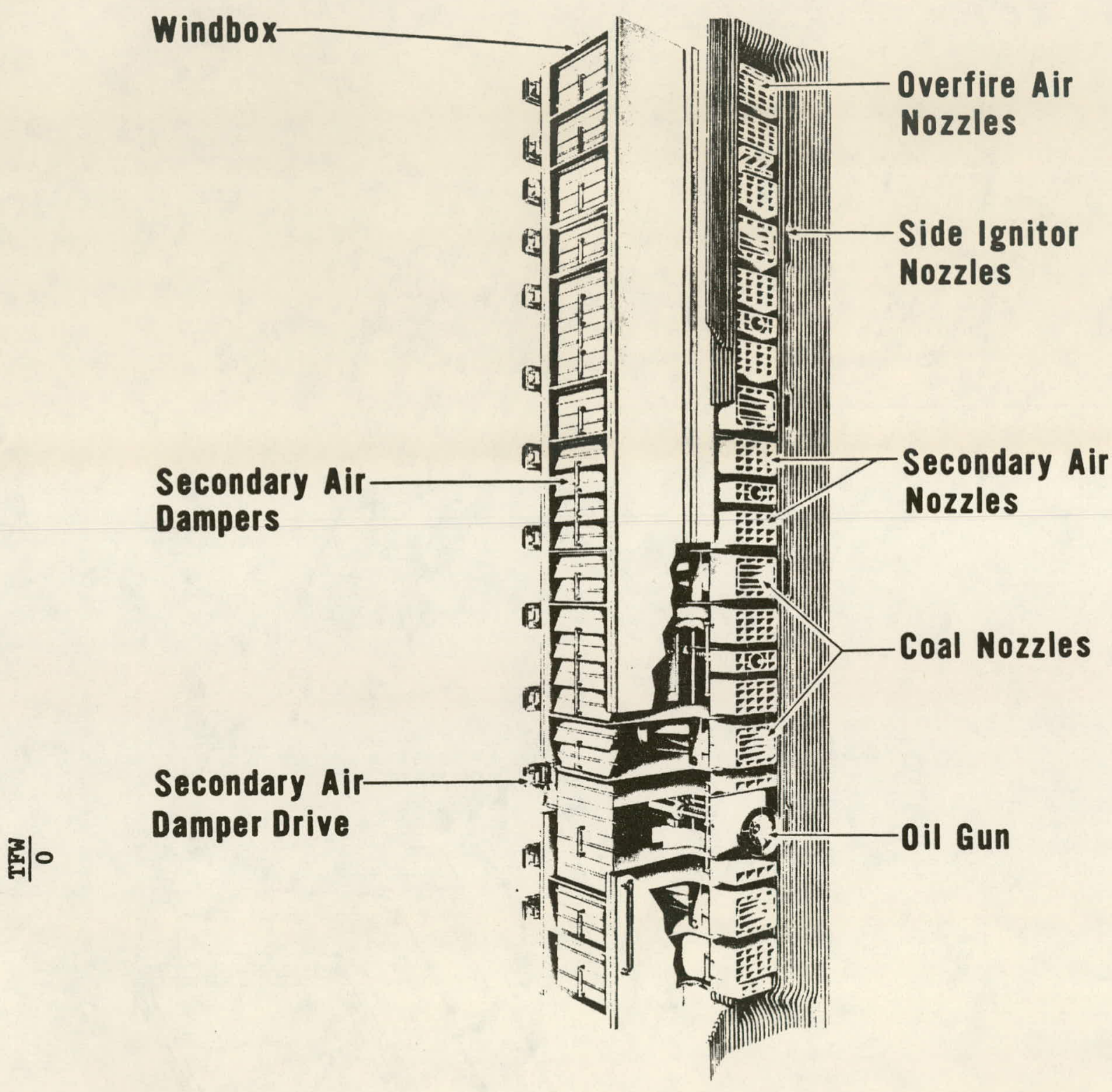

\section{ᄃ号 PYWER}

Illustration is typical of design, but does not necessarily show exact details of construction. 


\section{TYPICAL MATER-COOLED COMPARTMENT}

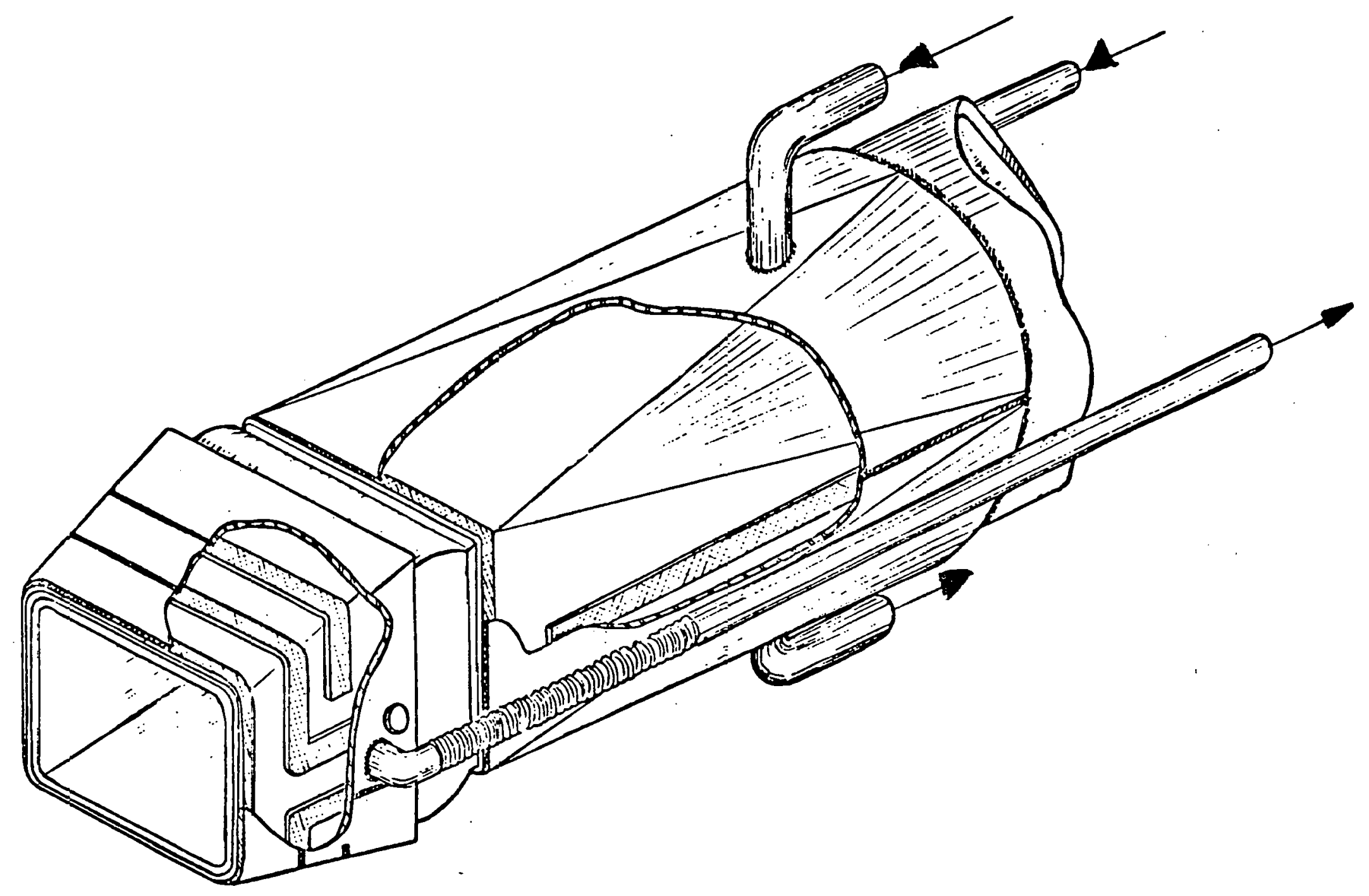


A FSSS will be provided for the automatic sequential control of the preparation, distribution, and admission of fuel and air into the furnace. The FSSS will perform the following functions, startup, shutdown, safety supervision, coordination, monitoring, and remote status display.

\section{FSSS Equipment}

One (1) Control console insert (switches pushbuttons and indicating lamps)

One (1) Control Cabinet

Eight (8) Locally mounted ignitor control cabinets with integral mounted isolation valving

Eight (8) Locally mounted warmup gas control cabinets

Twelve (12) Fireball flame scanners

One (1) Ignitor gas header double block and vent vaive

Eight (8) Ignitor gas trip vaives

One (1). Warmup gas header double block and vent valves

Eight (8) Warmup gas elevation double block and vent valves

Miscel laneous pressure switches 


$$
\begin{aligned}
\text { SECTION III - STEAM GENERATOR AND } \\
\text { PROCESS COIL }
\end{aligned}
$$




$\frac{\text { Location }}{\text { Upper }} \quad \frac{\text { Number }}{1} \quad \frac{\text { Length* }}{25^{\prime} 0^{\prime \prime}} \quad \frac{\text { Inside Diameter }}{60^{\prime \prime}}$

(*) Weld to weld

Centrifugal Separator Internals (Figure 6)

Downcomers

Number $\quad$ Outside Diameter

2

18.00 
FIGURE 6

\section{DRUM INTERNALS}

CENTRIFUGAL TYPE

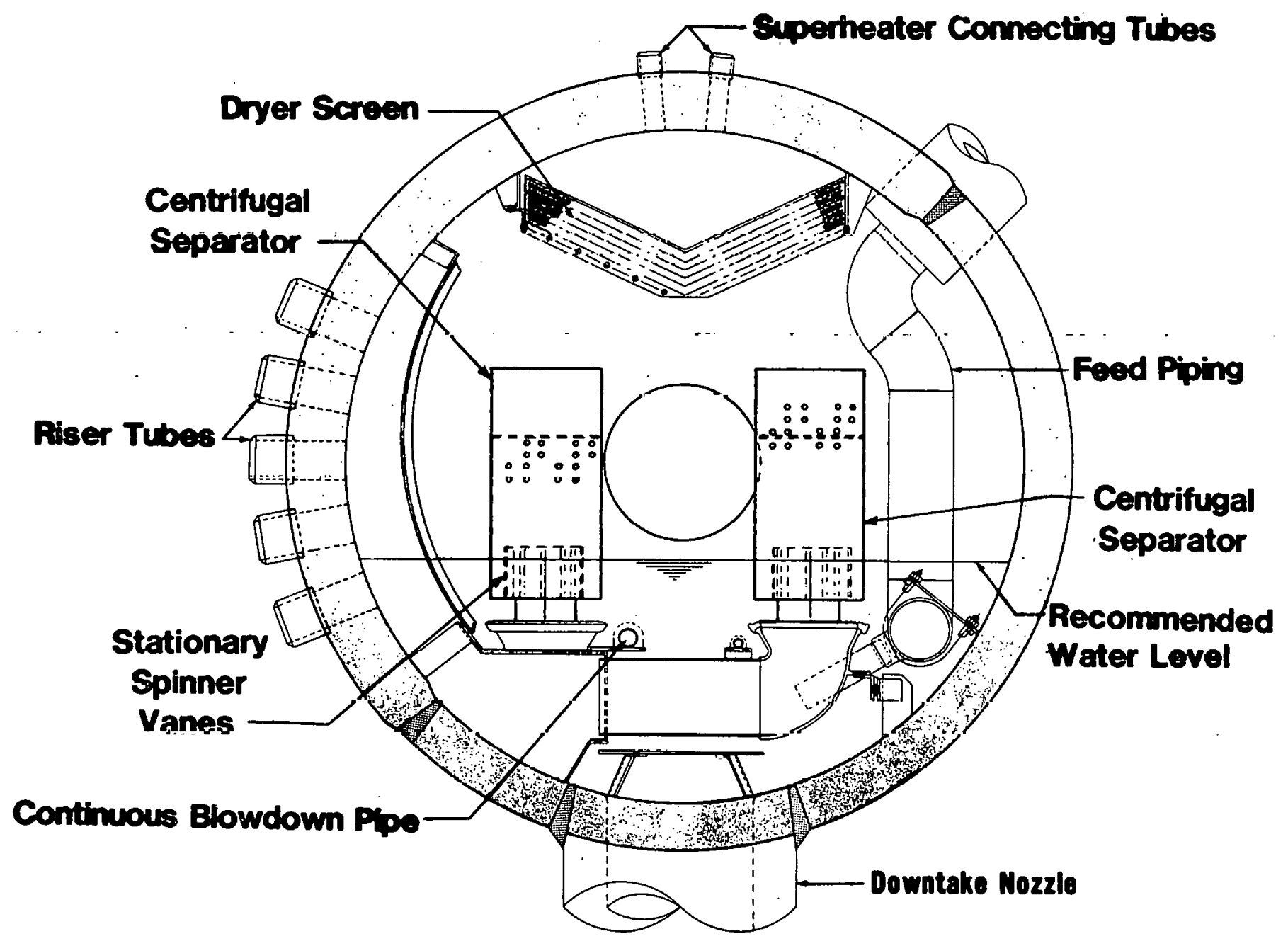

\section{鸟 SPYSTENS}

Illustration is typical of design, but does not necessarily show exact details of construction. 
Tubes

\section{Location}

Furnace Front Wall o Roof

Furnace Rear Wall

Furnace Side Walls

\author{
Number
}

120

120

273
O.D.

2.500

2.500

2.500
MWT*

.188

.188

.188
Type

Construction

Fusion Welded

Fusion Welded

Fusion Welded

\section{Waterwall Relief Tubes}

Front Wal1

Rear Wall

Side Walls
30

5.563

.375

30

5.563

.375

52

4.500

.300

(*) Minimum Wall Thickness

Lower Headers, 0.D. $=16.00 \mathrm{in}$.

Upper Headers, 0.D. $=8.625$ in.

Approximate Furnace Projected Surface: $16,750 \mathrm{ft}^{2}$

Approximate Furnace Volume: $105,200 \mathrm{ft}^{3}$

Furnace Width: $29.917 \mathrm{ft}$.

Furnace Depth: $33.917 \mathrm{ft}$.

\section{Furnace Gas-Side Pressure}

The furnace will be capable of withstanding an internal pressure of \pm 26 in. of water gage. 
Steam Cooled Wall Supply Tubes

$\begin{array}{cccc}\text { Number } & \underline{0 . D} . & \text { MWT } & \text { Material } \\ 20 & 4.50 \mathrm{in} . & 0.300 \mathrm{in} & 106 \mathrm{~B}\end{array}$

Cavity Walls

57 tubes wide

Material: SA-210

Spacing: $2.50 \mathrm{in}$.

MWT: -. .180 in.

OD: $\quad 2.00 \mathrm{in}$.

Process Coil Steam Cooled Walls

196 tubes wide

Material: T-1

Spacing: $4.00 \mathrm{in}$.

MWT : $\quad .180 \mathrm{in}$.

OD: $\quad 2.00 \mathrm{in}$. 


\section{FORM NO. $560(6.58)$ \\ Combustion Engineering, Inc. \\ HTILITY PRODUCTS, PERFORIANCE DESIGN}

Windsor, Conn.

SUPERHEATER, PROCESS COIL AND ECONOMIZER

Page No.

Contract No. 900347 _... Name_EDS Hybrid Boiler

No. of Blrs... 4

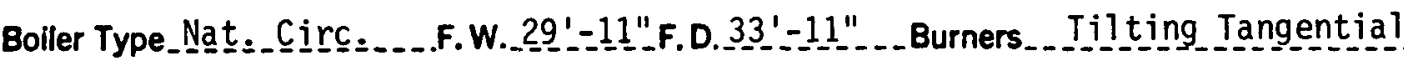

Fuel... Ill inois Coal or Vacuum Bottoms

Specs.

Proposal

DESIGN PERFDRMANCE DATA Negotiation No.

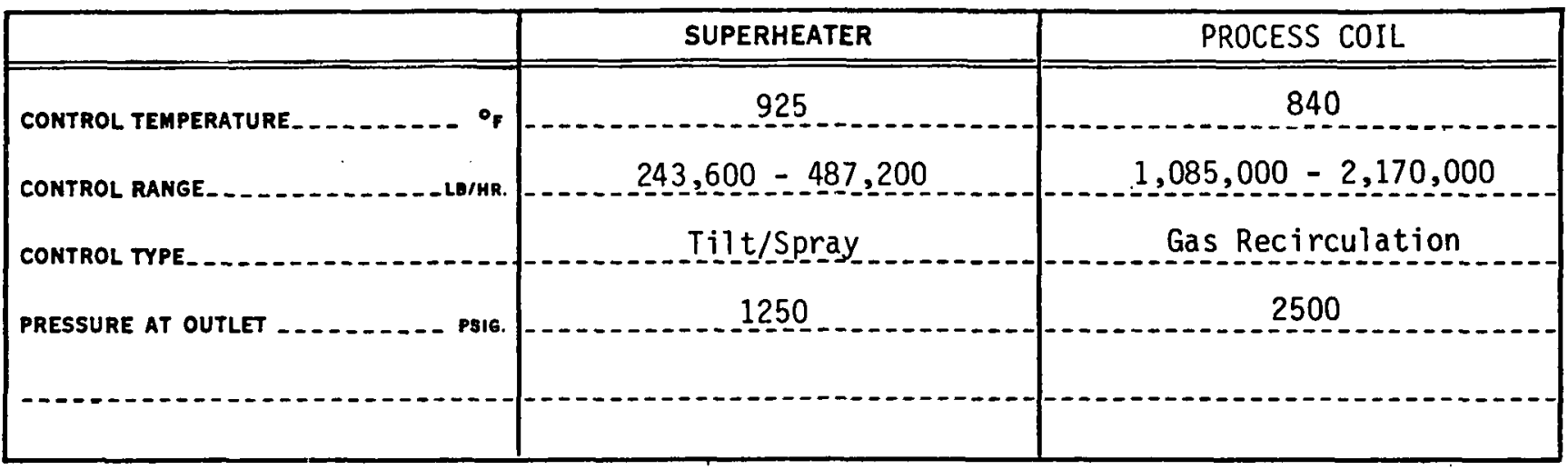

\section{ARRANGEMENT DATA}

Quantities indicated are per boiler. Heating surfaces are gas touched unless specified otherwise.

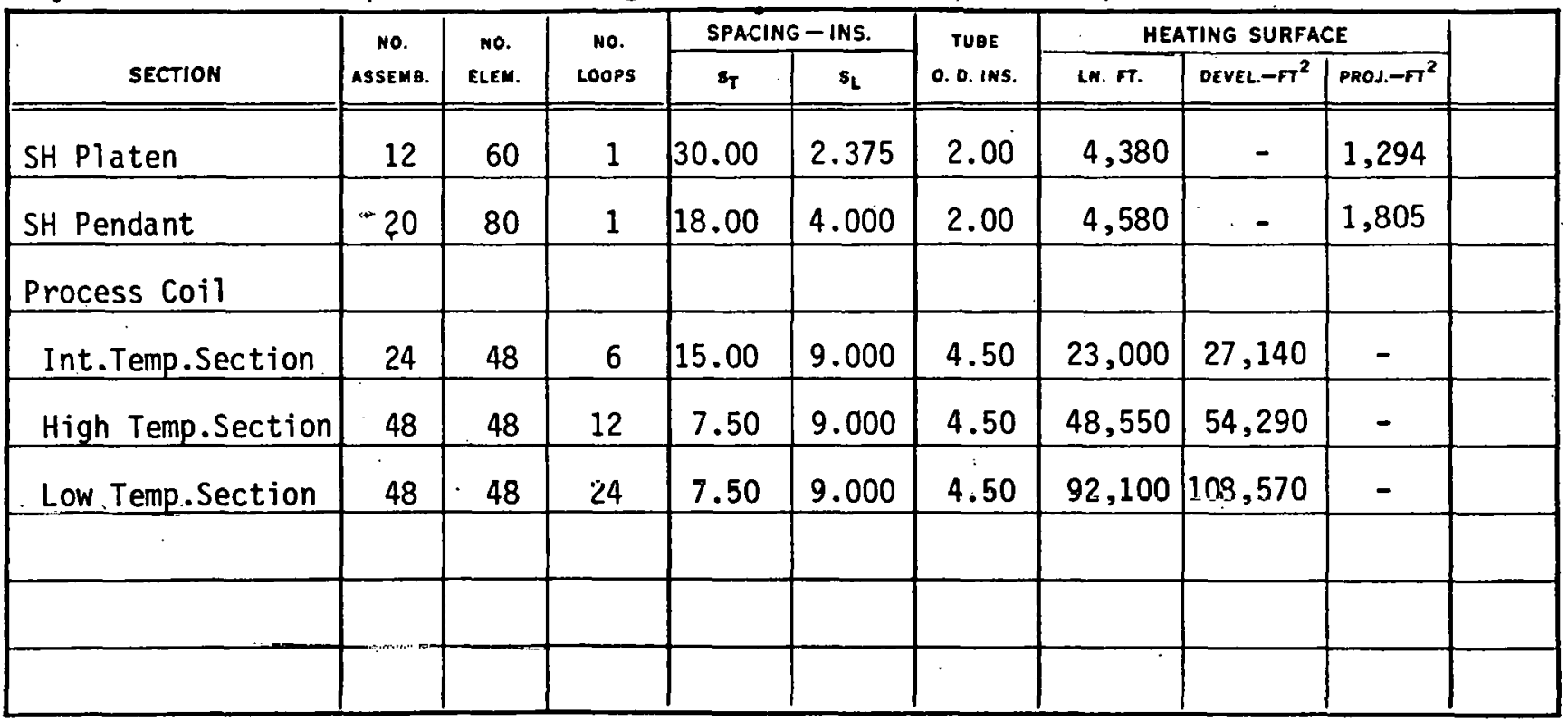

Remarks 
Combustion Engineering, Inc.

UTILITY PRODUCTS, PERFORMANCE DESIGN

SUPERHEATER, PROCESS COIL AND ECONOMIZER

Page No.

Contract No._. 900343 _. _. Name _. EDS Hybrid Boiler

HEADERS, PIPING AND MISC. DATA

Quantities indicated are per boiler.

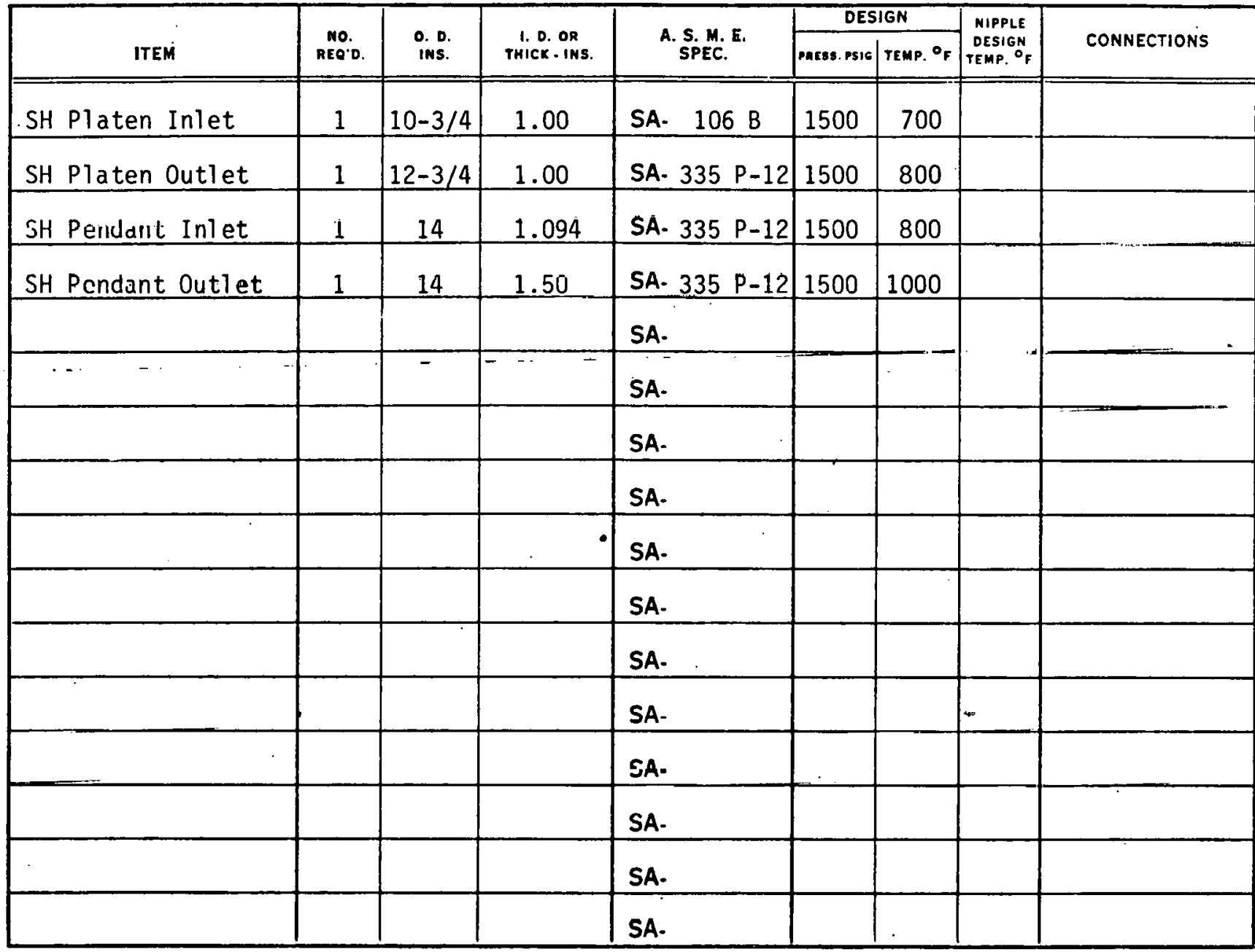

Remarks 


\section{PROCESS COIL}

\section{Material: $\mathrm{SA}-213 \mathrm{TP}-304 \mathrm{H}$}

\section{Specifications}

Tube 0.D.

4.50 in. .612 in.

$4.50 \mathrm{in.} \quad .661 \mathrm{in.}$

4.50 in. $\quad .612$ in.
Tubes Deep

24

24

48
$\underline{S_{T}} \quad \underline{S_{L}}$

15 in. 9 in.

7.5 in. 9 in.

7.5 in. 9 in. 


\section{FIGURE 7}

\section{EDS HYBRID BOILER}

\section{MASS FLOW AND TEMPERATURE PROFILES}

The mass flow and temperature profiles shown below are the predicted unbalance values entering the process coil. These values do not account for the mediating effects of the screen tubes and cavity upstream of the coil entrance.

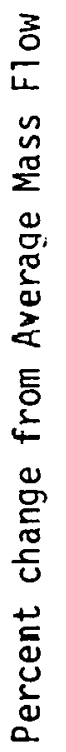

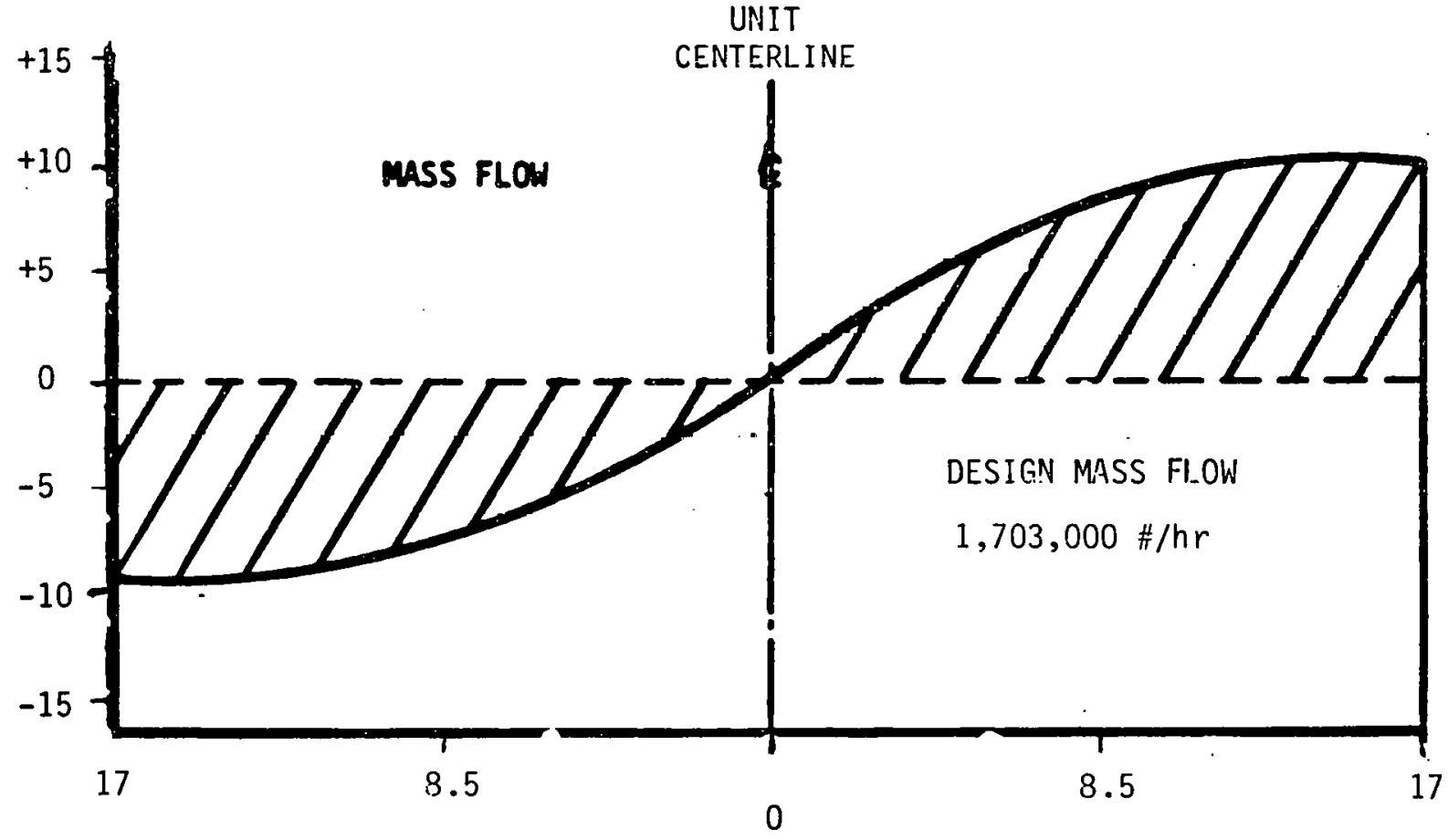

UNIT

FEET FROM CENTERLINE

+

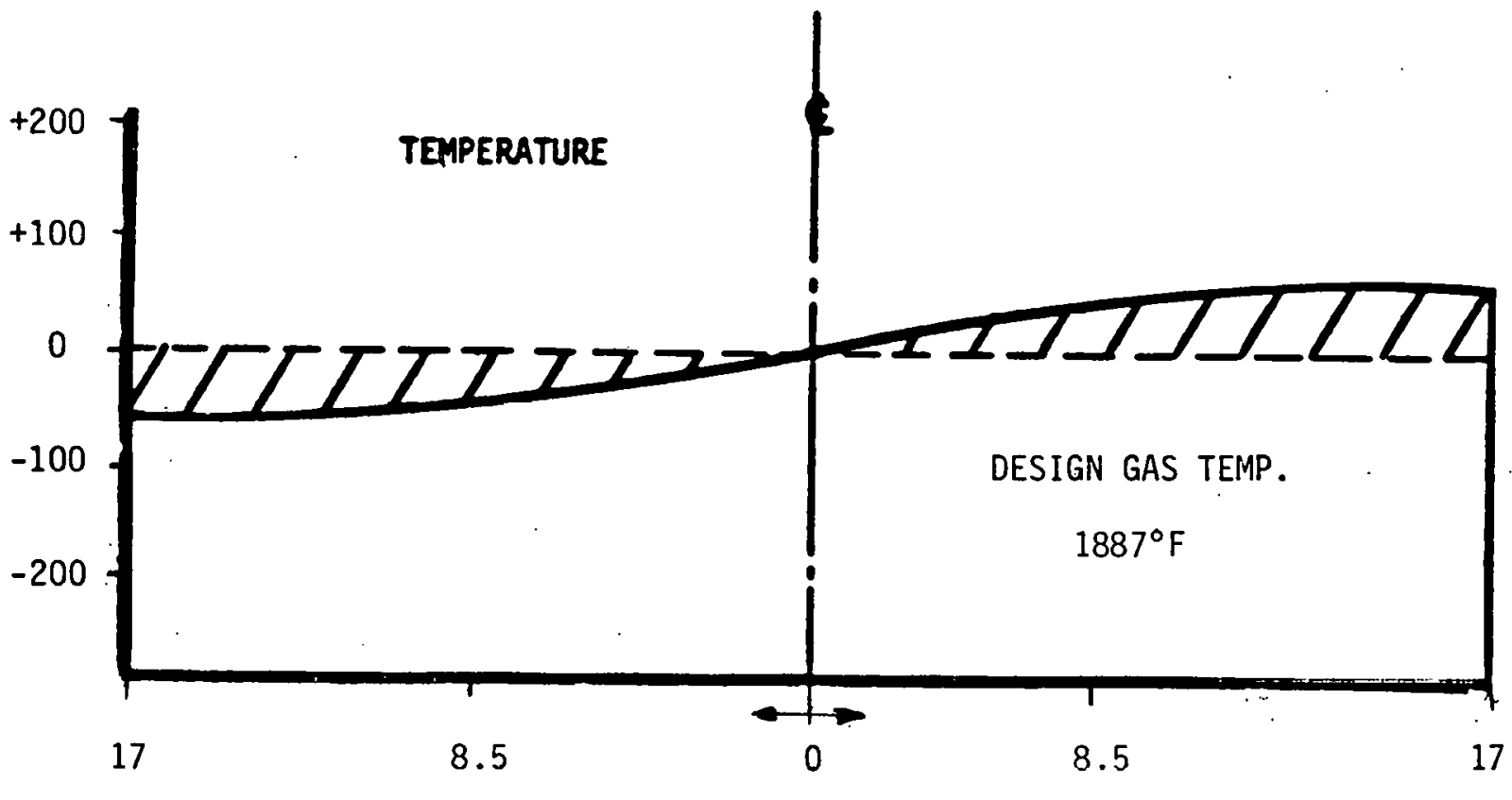

FEET FROM CENTERLINE 
FIGURE 8

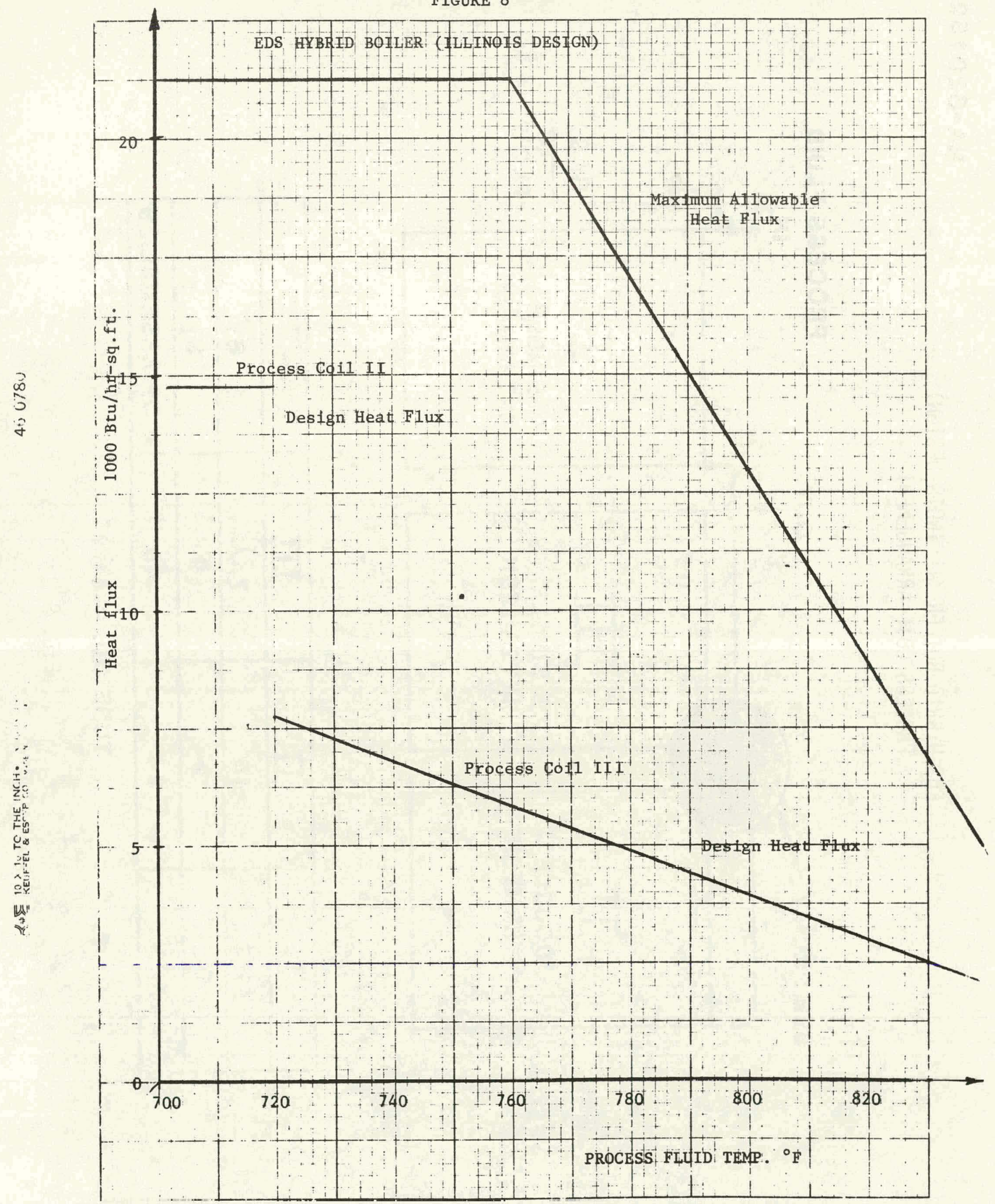




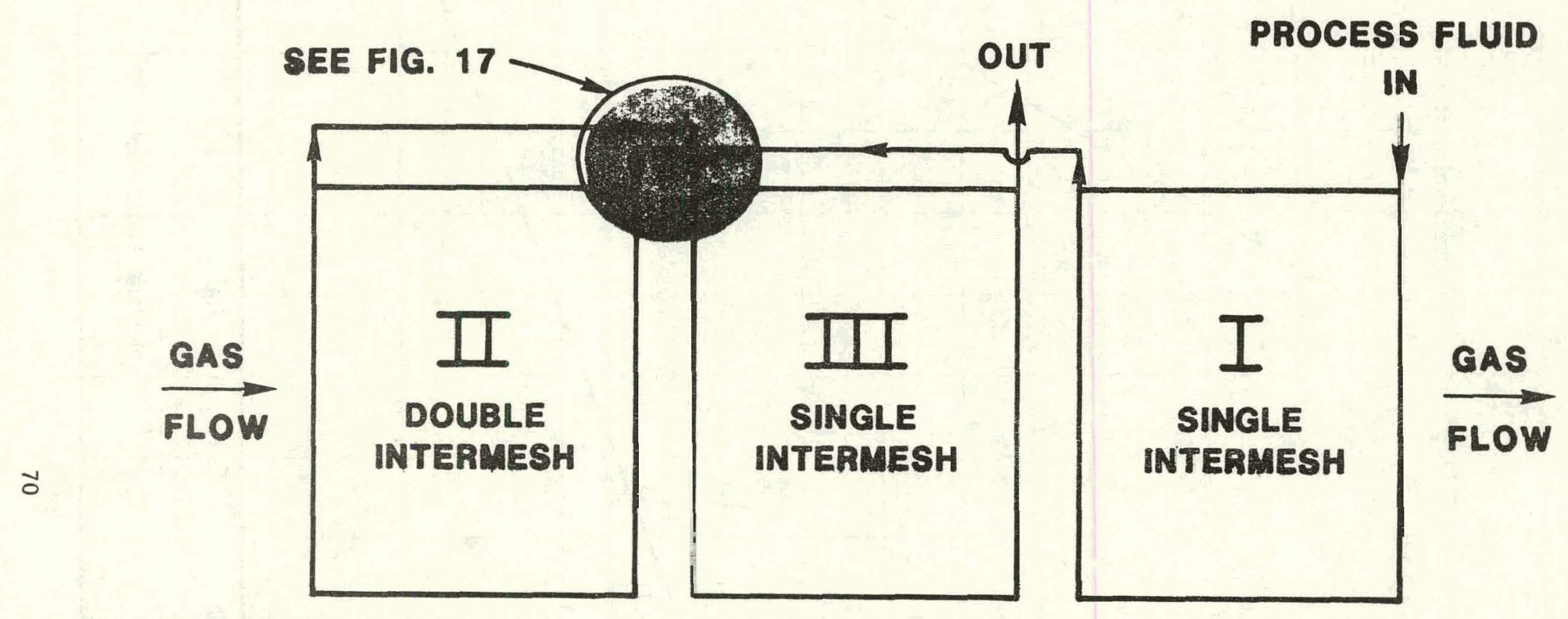

\begin{tabular}{|c|c|c|c|}
\hline$I$ & II & III & \\
\hline $71 / 2$ & 15 & $71 / 2$ & $S_{T}$ \\
\hline$\theta$ & 9 & 9 & $S_{L}$ \\
\hline 48 & 24 & 48 & \# OF ASSEMBLIES \\
\hline \multicolumn{4}{|c}{ TUBE QD. $=41 / 2^{\mu}$}
\end{tabular}

FIG. 9 
EDS HYBRID BOILER ILLINOIS EDS

PROCESS COIL ARRANGEMENT

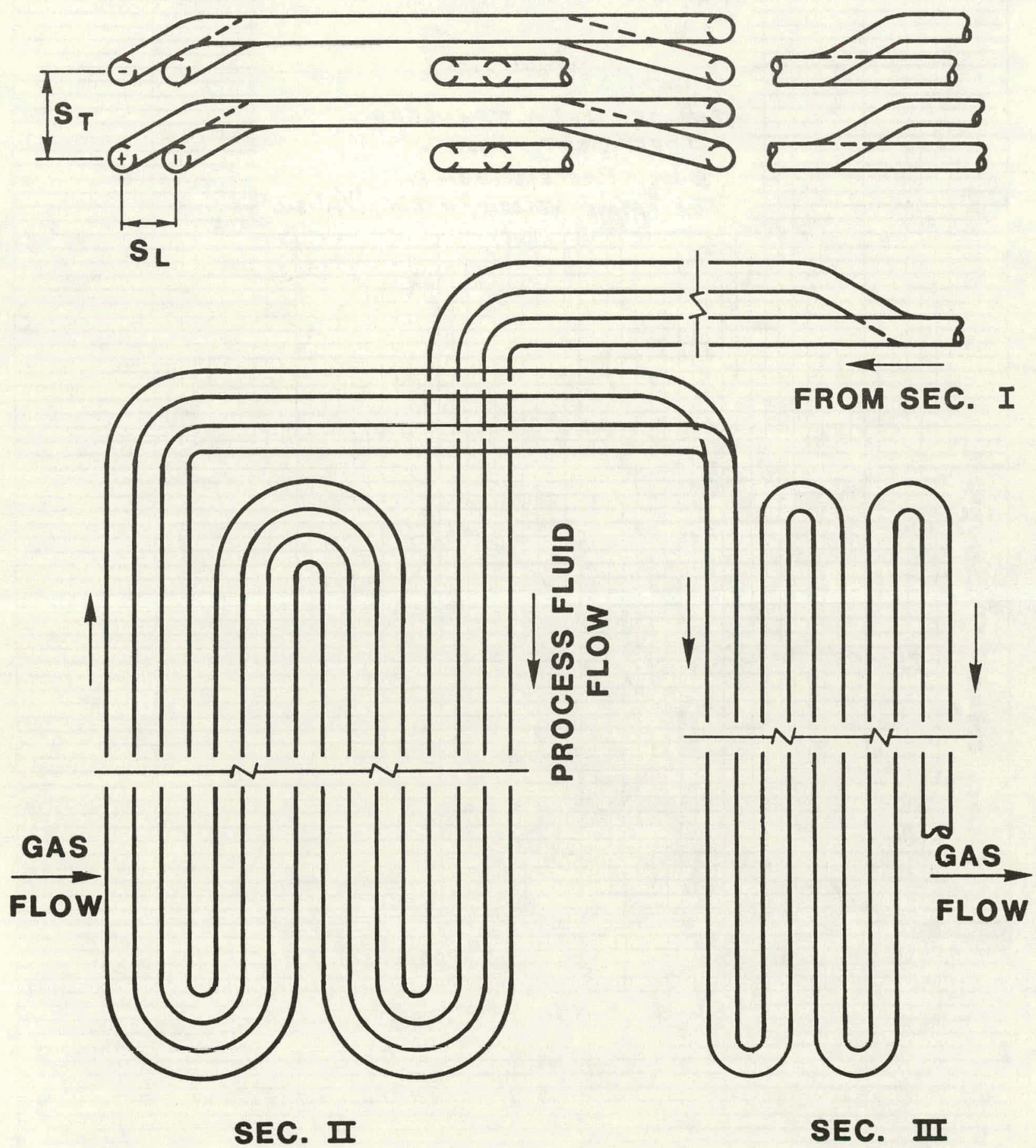

FIG. 10 


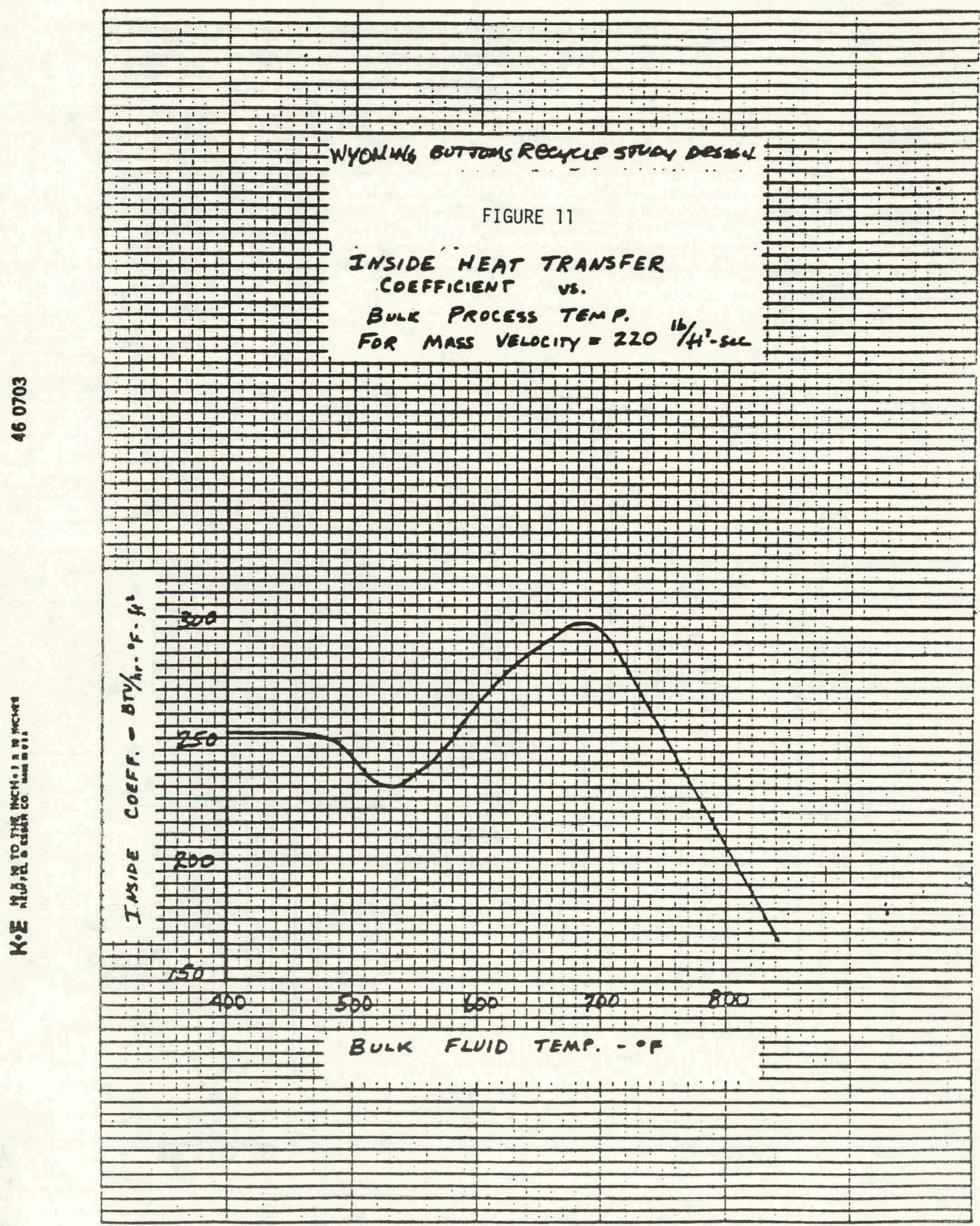




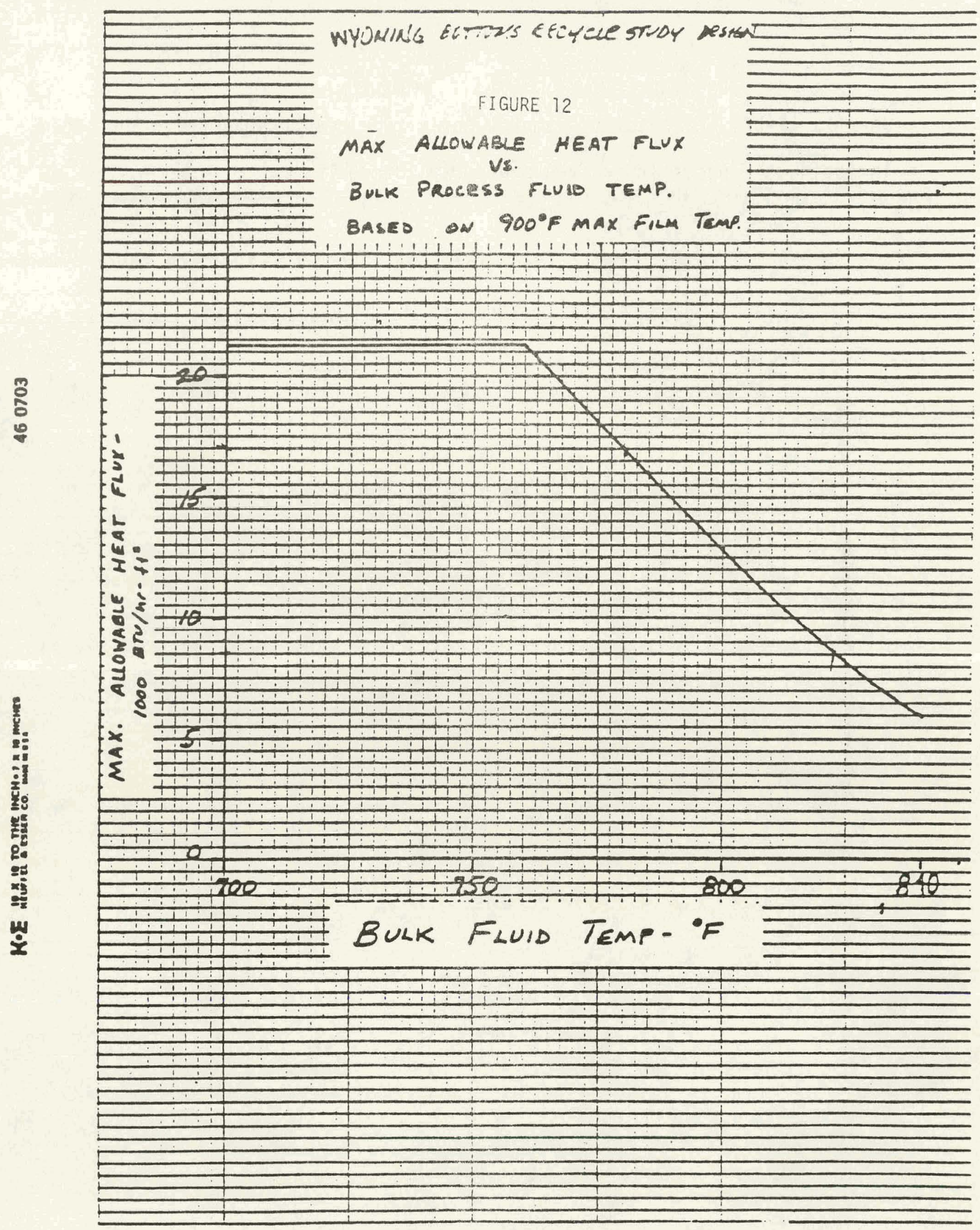




\section{DESUPERHEATER}

One (1) 12-3/4 in. outside diameter spray type desuperheater for the steam, including the necessary valves and spray internals.

Spray temperature: $250^{\circ} \mathrm{F}$

Maximum spray flow: $50,000 \mathrm{lbs} / \mathrm{hr}$ 
FIGURE 13

\section{C-E DESUPERHEATER}

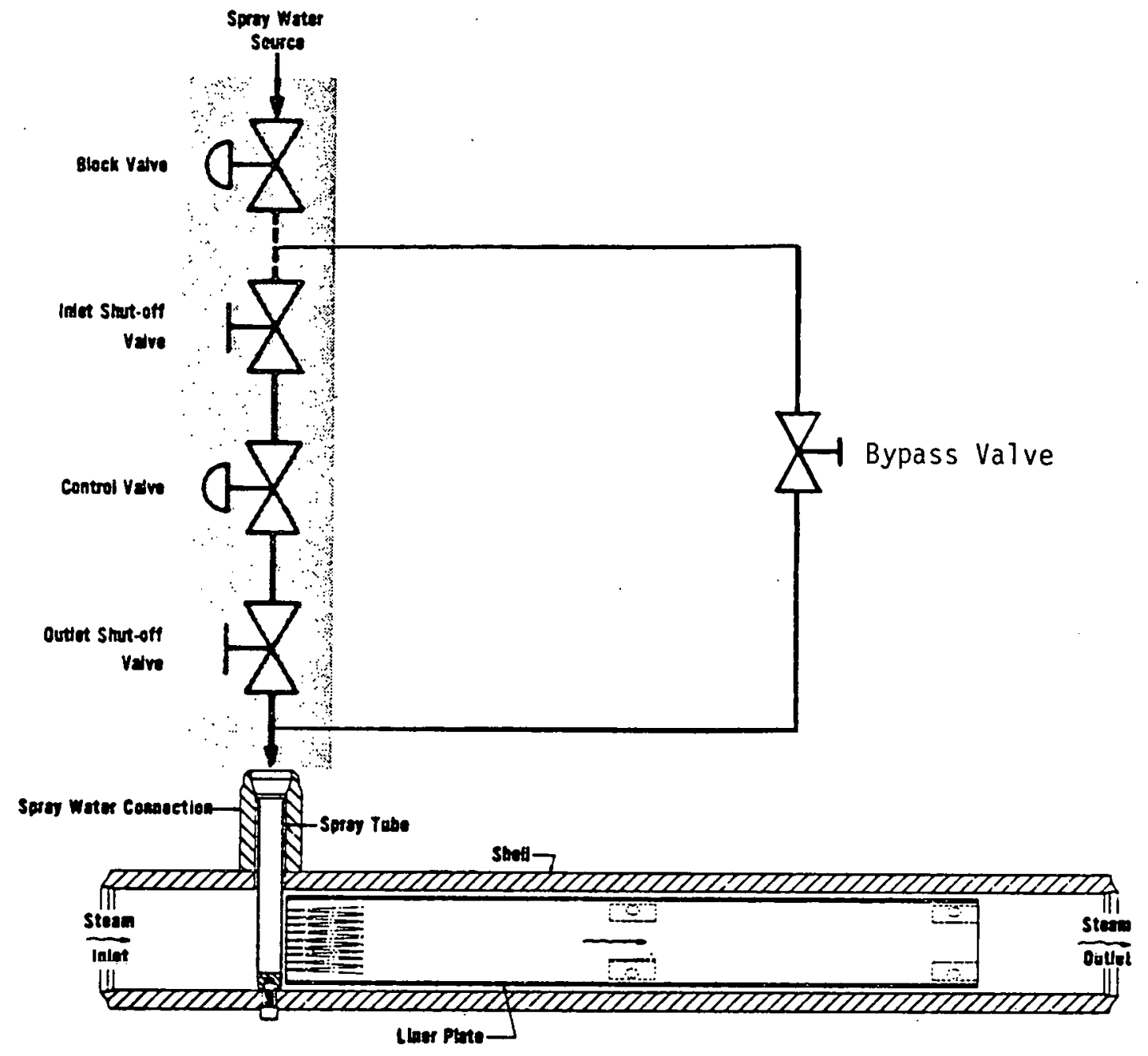

\section{氜饲 POWSTEMS}

Illustration is typical of design, but does not necessarily show exact details of construction. 
SECTION IV - AUXILIARY EQUIPMENT 
3-pass tubular air heater with the gas through the tubes and secondary air over the tubes (see Figure 8 ).

$\begin{array}{ll}\text { Diameter of tubes: } & 2.5 \text { inches } \\ \text { Thickness: } & 12 \text { gauge } \\ \text { Number of tubes wide: } & 113 \text { per pass } \\ \text { Number of tubes deep: } & 50 \text { per pass } \\ \text { Tubes spacing - width: } & 3.125 \text { inches } \\ \text { Tubes spacing - depth: } & 3.125 \text { inches } \\ \text { Tube material: } & \text { SAE-1010 } \\ \text { Total heating surface: } & 283,255 \text { sq.ft. }\end{array}$




\section{C-E TUBULAR AIR HEATER}

TUBE FERRULE (TYP.)

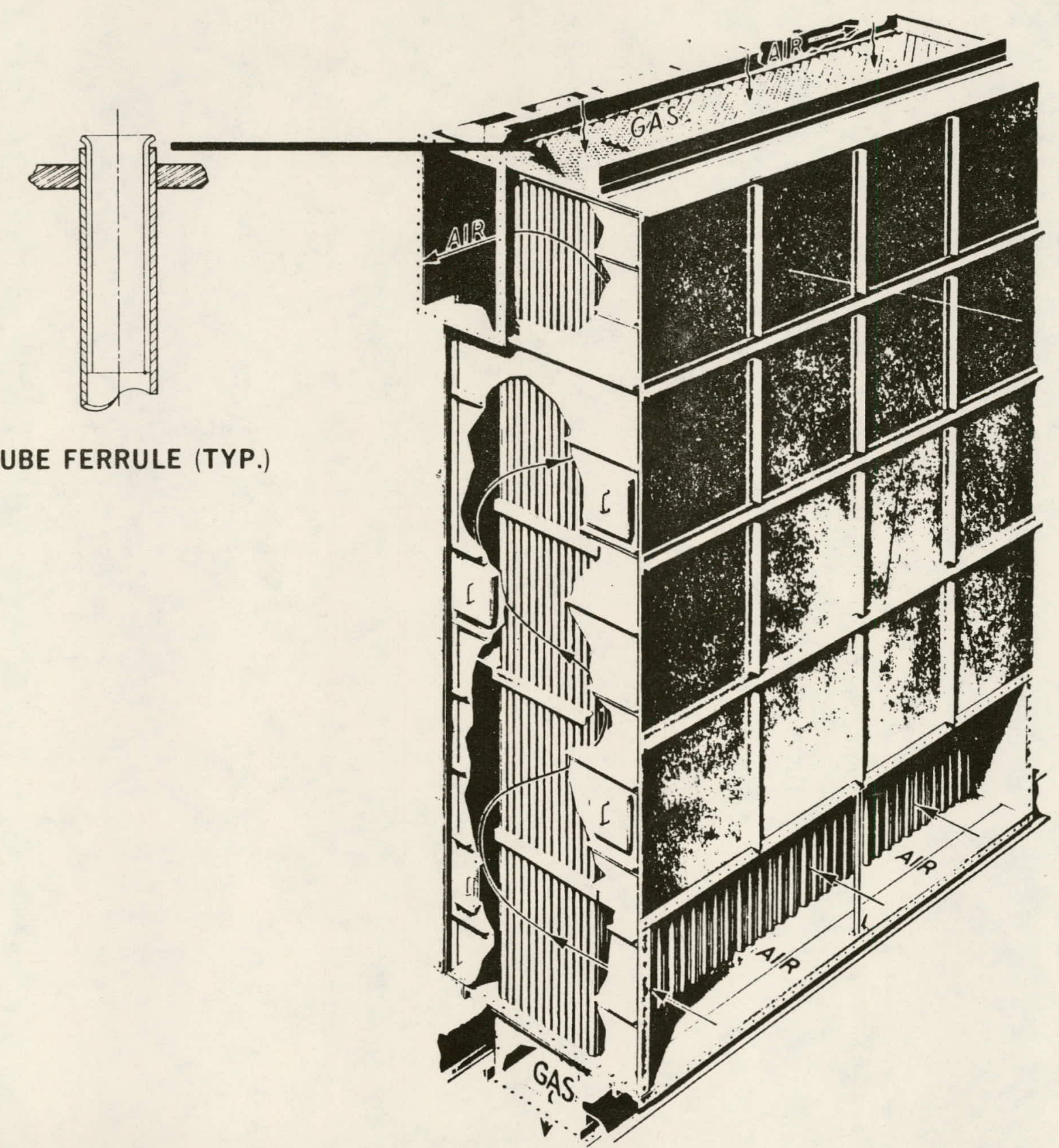


The fan specifications are such that the fans can provide $60 \%$ of the full flow rate with either one forced draft or one induced draft fan out of service. If one primary air fan is out of service, $66 \%$ air flow to the mills can be achieved. All fans are motor driven, constant speed units.

\section{Primary Air Fan}

Description
Number of Fans
Volumetric Flow (cfm)
Static Pressure Rise (in.wg)
Operating Speed (rpm)
Type of Control

Description Actual 2 114,000 29.0 1800

Inlet Vanes
Test Block
142,590
43.5
1800

Inl et Vanes

\section{Forced Draft Fan}

Description

Number of Fans

Volumetric Flow (cfm)

Static Pressure Rise (in.wg)

Operating Speed ( $\mathrm{rpm}$ )

Type of Control
Actual

2

634,900

13.10

1800

Inlet Vanes
Test Block

761,900

18.85

1800

Inlet Vanes

Induced Draft Fan

Description

Number of Fans

Volumetric Flow (cfm)

Static Pressure Rise (in.wg)

Operating Speed ( $\mathrm{rpm}$ )

Type of Control
Actual

2

$$
1,021,750
$$

$-10.4 /+12.00$

900

Inl et Vanes
Test Block

$1,226,100$

$-14.55 / 16.80$

900

Inl et Vanes 


\section{GAS RECIRCULATION SYSTEM}

Gas is recirculated from the outlet of the induced draft fan to the bottom of the furnace for process coil outlet temperature control +12.00 in.wg at the outlet of the ID fan assures adequate head to recirculate the flue gas.

Control of the gas flow is provided through two sets of dampers; one in the main duct to the stack and another one in the GR duct.

GR duct cross-section: 32 sq.ft. 


\section{DUCTWORK}

The ductwork included in C-E's scope of supply:

\section{Air Ducts}

From the outlet of the forced draft fan to the secondary air heater. From the outlet of the secondary air heater to the windbox.

In the primary air system, from the outlet of the P.A. fans to the pulverizer.

\section{Gas Ducts}

From the outlet of the process coil to the inlet of the secondary air heater.

Between the outlet of the secondary air heater and the electrostatic precipitator.

Ductwork associated with the I.D. fans and into ducts acting as 4 unit common plenum's between the ESP and the FGD modules.

Gas recirculation ductwork running from the outlet of the induced draft fans to the bottom of the furnace.

Duct connecting the six FGD modules to the stack. 


\section{SOOTBLOWING SYSTEM}

The following electrically operated, automatic-sequential equipment are included in the Sootblowing System:

- 60 Wall Blowers

Each blower includes an electric motor drive, mechanically operated valve with adjustable pressure control, stellited valve seats and disc.

- 39 Retractable Blowers w1th 30 rL: Travel --

For the individual sootblower location see drawing EP-813-199-4 
All four Hybrid Boilers in the boiler island designed for the Illinois location feed into a single common stack.

\begin{tabular}{ll} 
Material: & Corten Steel \\
Gas Temperature: & $300^{\circ} \mathrm{F}$ \\
Stack Diameter: & $23.5 \mathrm{ft}$. \\
Stack Height: & $250 \mathrm{ft}$. \\
Stack Thickness: & \\
Elevation & Thickness \\
\hline $0-60 \mathrm{ft}$. & $3 / 4 \mathrm{in}$. \\
$60-80 \mathrm{ft}$. & $5 / 8 \mathrm{in}$. \\
$80-140 \mathrm{ft}$. & $1 / 2 \mathrm{in}$. \\
$140-200 \mathrm{ft}$. & $3 / 8 \mathrm{in}$. \\
$200-250 \mathrm{ft}$. & $1 / 4 \mathrm{in}$.
\end{tabular}


SECTION V - FLUE GAS CLEAN UP SYSTEM 


\section{ELECTROSTATIC PRECIPITATOR}

The electrostatic precipitator has frame work for six fields with five fields initially installed. Each field contains discharge and collection electrodes,

electrode rappers for cleaning. Underneath the field is a hopper for temporary storage of particulate.

Scope of Supply

Precipitator, flange to flange

Transitions

Access

Support Steel

Insulation and Lagging (material only)

Instruction Manuals

Gas Flow Model Study

Erection Representative

Service Representative

Freight

(Foundations and Buildings not included) 


\section{C-E WALTHER PRECIPITATOR}

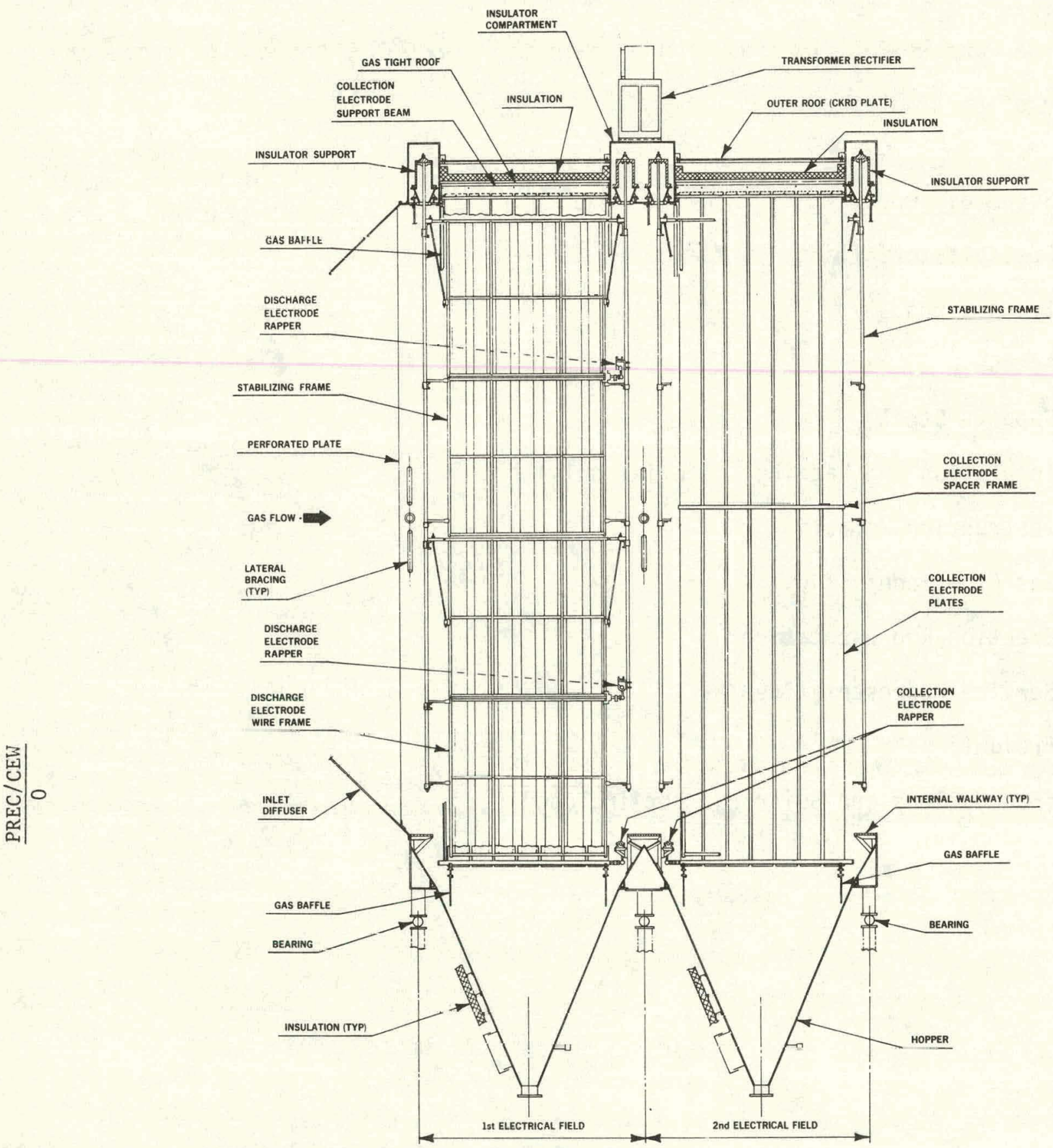

\section{들 POWER}

Illustration is typical of design, but does not necessarily show exact details of construction. 


\section{EDS HYBRID BOILER \\ ILLINOIS EDS DESIGN \\ WET SCRUBBER - SCOPE OF SUPPLY \\ (Foundations and buildings are not included)}

Absorber System:

Absorbers

Reaction Tanks

Mixers

Spray Pumps \& Drives

Spray Piping

Additive System:

Milling Equipment (incl. drives), Ball Mills

Sotrage Bins

Storage Tank \& Mixer

Feed Pumps \& Drives

Additive Piping

Reheat System:
Auxiliary Equipment:

Ductwork, Dampers \& Expansion Joints

Insulation \& Lagging

Structural Steel \& Platforms

Bl ower System

Control System

Wash Water Pump \& Drive

Wash Water Piping

Misc. Piping \& Hangers \& Supports

Balance of Plant:

Electrical Equipment
Services:

Instruction Manuals

Training Program

Design Model

Gas Flow Model Study

Erection Representative

Service Representative

Freight 
Both the bottom ash, falling through the opening at the bottom of the furnace, and the flyash collected from the process coil hopper will be collected in submerged scrapper conveyors (SSC). The process coil SSC will discharge through a chute into the bottom ash SSC to provide a common point for removal. Pulverizer rejects, consisting of tramp iron and heavy mineral matter will be rejected from the pulverizer into temporary storage tanks. The contents of these tanks will be sluiced to the bottom ash SSC for removal from the system.

The Pulverizer Rejects Removal System per boiler consists of:

4:- Pyrites hoppers, 1/pulverizer, $13 \mathrm{ft}^{3}$ capacity of the pressurized type

4 - Pulverizer-to-hopper discharge chutes with knife edged isolation gate

Each hopper will be furnished with:

1 - Jetting nozzle

$-$

1 - Level indicator

1 - Hinged access pane1

1 - steel grate for manual removal of rejects larger than $1 \frac{1}{2}$ inches

1 - Floudl ightl

4 - Jet pumps will be furnished to carry rejects to the bottom ash SSC.

4 - Individual rejects hopper to bottom ash SSC transfer lines 


\section{FIGURE 16}

\section{C-E Submerged Scraper Conveyor (SSC)}

\section{DESCRIPTION}

The C-E Submerged Scraper Conveyor (SSC) is a device that continously removes bottom ash from under the furnace of steam generators. Operation is simple. Ash enters the SSC through the bottom throat of the furnace (or is discharged from a grate) into a water-filled trough. Angle flights attached to continuous moving parallel chains scrape the ash along the bottom of the trough and up an inclined section. Effectively dewatered, the ash drops off the end of the inclined section into a transfer chute, through a clinker grinder for transport to a disposal point. The flights then begin a return cycle under the water-filled trough, through an exposed dry trough area, to enter again the water-filled trough. Water temperature in the trough is maintained at $140 \mathrm{~F}$ - the same as in a conventional water impounded bottom ash hopper.

This method of mechanical conveying eliminates the need for pumps, pump motors, valves, piping and fittings otherwise required with water conveying methods. It also eliminates the power needed to drive this equipment. Since dewatering is accomplished on the inclined section of the SSC, dewatering vessels are not required. The final, dewatered ash contains 20 to $25 \%$ water by weight.

The continuous removal feature of this system eliminates the requirement for ash storage space under the boiler; hence, reduced boiler setting height is possible without resorting to the use of a pit as was common practice a few years ago. The realization of maximum cost savings from this feature will result only when the SSC is specified in the original boiler design-that is, at the time a proposal is prepared for boiler bid.

The entire SSC, including the inclined section, is mounted on wheels and can be rolled out on rails from under the furnace. This feature allows complete access to the SSC for maintenance. It also provides full access to the furnace through the furnace bottom throat.

The SSC is shipped in two or three pieces. This greatly reduces erection manhours as compared tu cunvenliurial bottom ash hopper systems.

By its very nature, continuous ash removal eliminates hopper storage under the furnace and imposes the requirement that bottom ash be continuously transported to ultimate disposal. If full time transport to a disposal site is not pussible, some type of intermediate storage of the dewatered bottom ash will be required.
The SSC can receive pyrites and economizer ash and thus serve as a transfer tank. In some industrial applications, where water quenching of high carbon content fly ash to eliminate the fire or explosion hazard is desirable, the backend fly ash is also deposited into the water trough of the SSC. These applications above also result in a single plant ash discharge inherently simplifying the disposal of ash.

\section{BENEFITS}

- Provides continuous bottom ash removal

- Uses less pumping power and less water than pipeline systems

- Costs less to erect than conventional bottom hoppers

- Accomplishes dewatering without the use of dewatering vessels

- Is easily moved for access to the furnace

- Allows reduced boiler setting height

- Provides low-cost, water quenching system for high combustible ash with minimum use of real estate

\section{SPECIFICATIONS}

- Hydraulic or mechanical variable speed drive

- Water-flushed submerged bearings

- Carbon steel plate construction

- Low pressure cooling water

- Case hardened alloy steel chains

- Manual chain tensioning device

- Automatic chain flight cleaner

FOR ADDITIONAL INFORMATION, CONTACT:

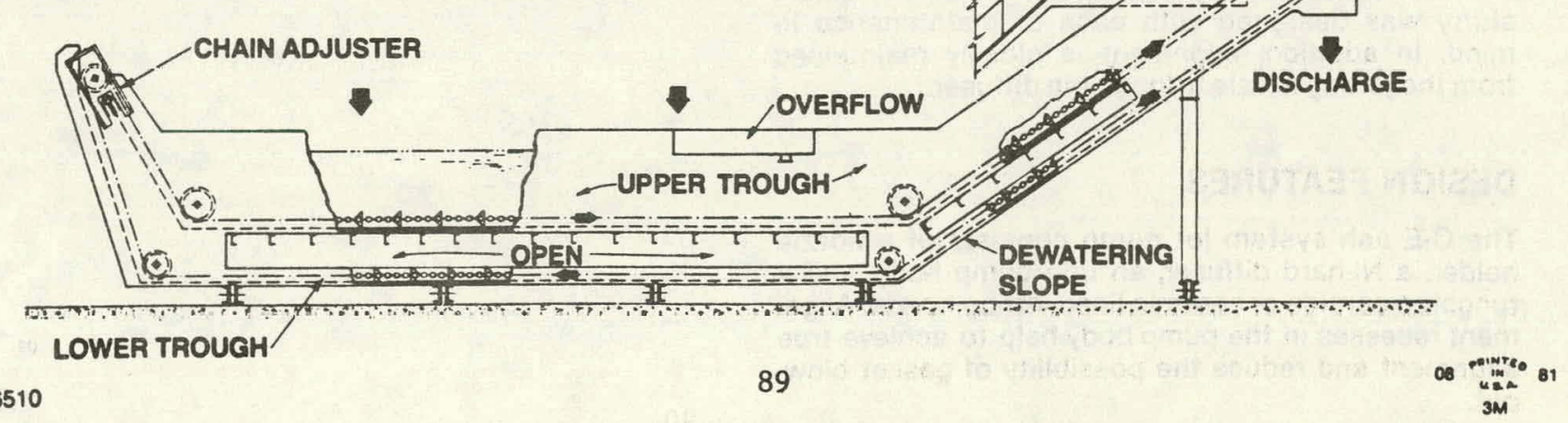




\section{C.E ash system jet pump}
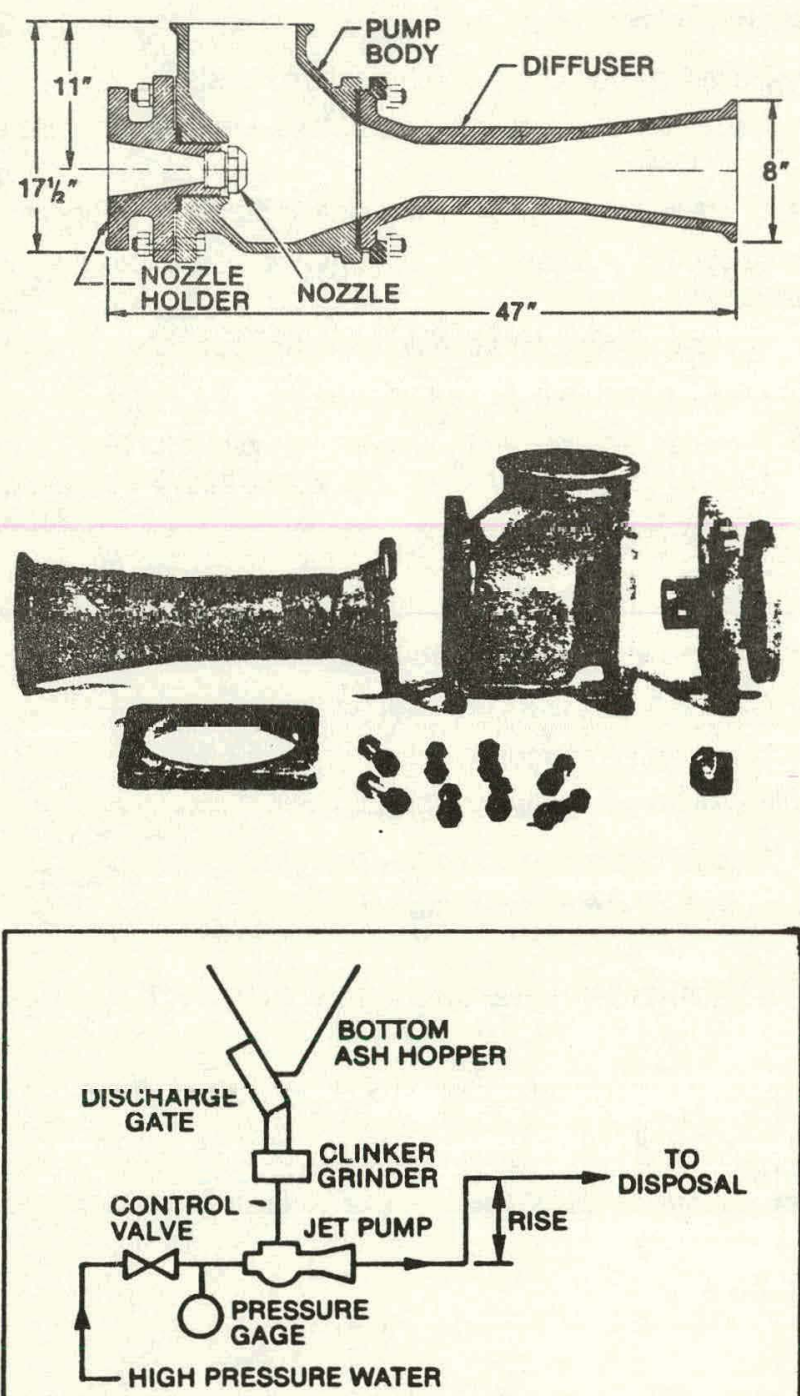

The C-E ash system jet pump for transporting ash slurry was designed with ease of maintenance in mind. In addition, alignment is closely maintained from the jetting nozzle through the diffuser.

\section{DESIGN FEATURES}

The C-E ash system jet pump consists of a nozzle holder, a Ni-hard diffuser, an iron pump body, and a tungsten carbide or ceramic-lined jetting nozzle. Align. ment recesses in the pump body help to achieve true alignment and reduce the possibility of gasket blowout.

\section{BENEFITS}

- Gives self regulating ash flow capability.

- Quick disassembly of component parts reduces maintenance downtime.

- Close alignment helps to maintain high efficiency.

- Low number of assembly parts simplifies maintenance and operation.

\section{SPECIFICATIONS}

Nozzle holder.......... standard 6-inch 300\# flange

Ni-hard diffuser ............. Brinell hardness: 550

(minimum); range of sizes available

Pump body ......... nodular iron, Brinell hardniess: 400 (minimum); sizes tailored to individual systems

Jetting nozzle ......... tungsten carbide or ceramie lining avain.

\section{FOR ADDITIONAL INFORMATION, CONTACT:}




\section{C-E Model 830 clinker grinder}

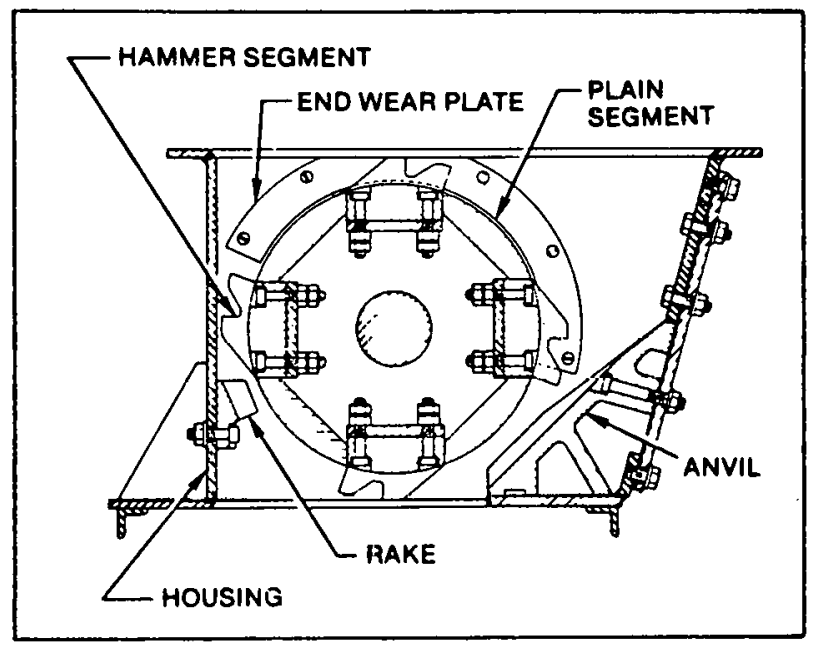

\section{DESCRIPTION}

The C-E Model 830 clinker grinder is an improved design that will effectively reduce bottom ash so it can be transported in a pipeline sluice conveyor while providing high reliability and power plant availability.

\section{DESIGN FEATURES}

The C-E Model 830 clinker grinder has been developed in light of today's power plant operating requirements for maintainability and reliability. Component materials have been selected with severe duty requirements in mind. Major features of the C-E Model 830 clinker grinder include:

- Tripod bearing-supports: to reduce shock loading transmitted from the grinder to the bearings.

- Access panel: access is provided to the grinder wear elements from the outside.

- Replaceable hammers and anvils: the C.E design simplifies maintenance by providing replaceable hammers, plain segments and anvils.

- Shaft seals: a new, improved arrangement reduces leakage through the grinder.

- Single roll design: reduces the weight, horsepower and number of moving grinder parts.

- Detached drive motor: allows easier removal of the grinder.

\section{BENEFITS}

- Increased salety for malntenance personnel by permitting outside access to wear parts.

- Time to replace worn wear elements is reduced.

- Smaller number of shafts, shaft sleeves and bearings provides improved maintainability.

- Motor drive does not have to be removed from the cllnker grinder housing for grinder changeout.

- Less grinder downtime due to reduced seal leakage.
FIGURE 18

\section{SPECIFICATIONS}

Seals require clean filtered water at a constant flow. Water pressure of $\mathbf{2 0} \mathbf{p s i}$ is required.

Housing and non-wear parts are supplied in carbon steel or stainless steel.

Wear elements are constructed of work-hardening manganese steel.

$10 \mathrm{hp}, 440 \mathrm{~V}$ gear motor drive. 


\section{PNEUMATIC FLYASH REMOVAL SYSTEM}

Flyash removed from the gas stream by the electrostatic precipitator and that falling from the gas stream in the air heater hopper will be pneumatically conveyed from the Hybrid Boiler. A vacuum transport system will be used for this service.

The pneumatic transport system for each unit will consist of:

25 - Air cylinder operated flyash intake valves

1/unit for the air heater hopper

24/unit for ESP hoppers

25 - Hopper maintenance gates

7 - Spring loaded air intake check valves, 1 at the end of each pneumatic leg

1 - Rotary blower vacuum producers per unit with 1 common spare

5 - Blower segregation valves

Each pair of units discharges to a common silo. This silo will consist of:

1 - $40 \mathrm{ft}$. diameter, $53,000 \mathrm{ft}^{3}$ storage silo consisting of:

2 - dual cyclone continuous separation modules

2 - silo bag filters acting as tertiary separation

1 - telescoping dry silo discharge chute

1 - rotary, wet ash, conditioning discharge chute

2 - fluidizing air blowers

2 - fluidizing air heaters

Silo fluidizing air troughs

1 - silo vent 


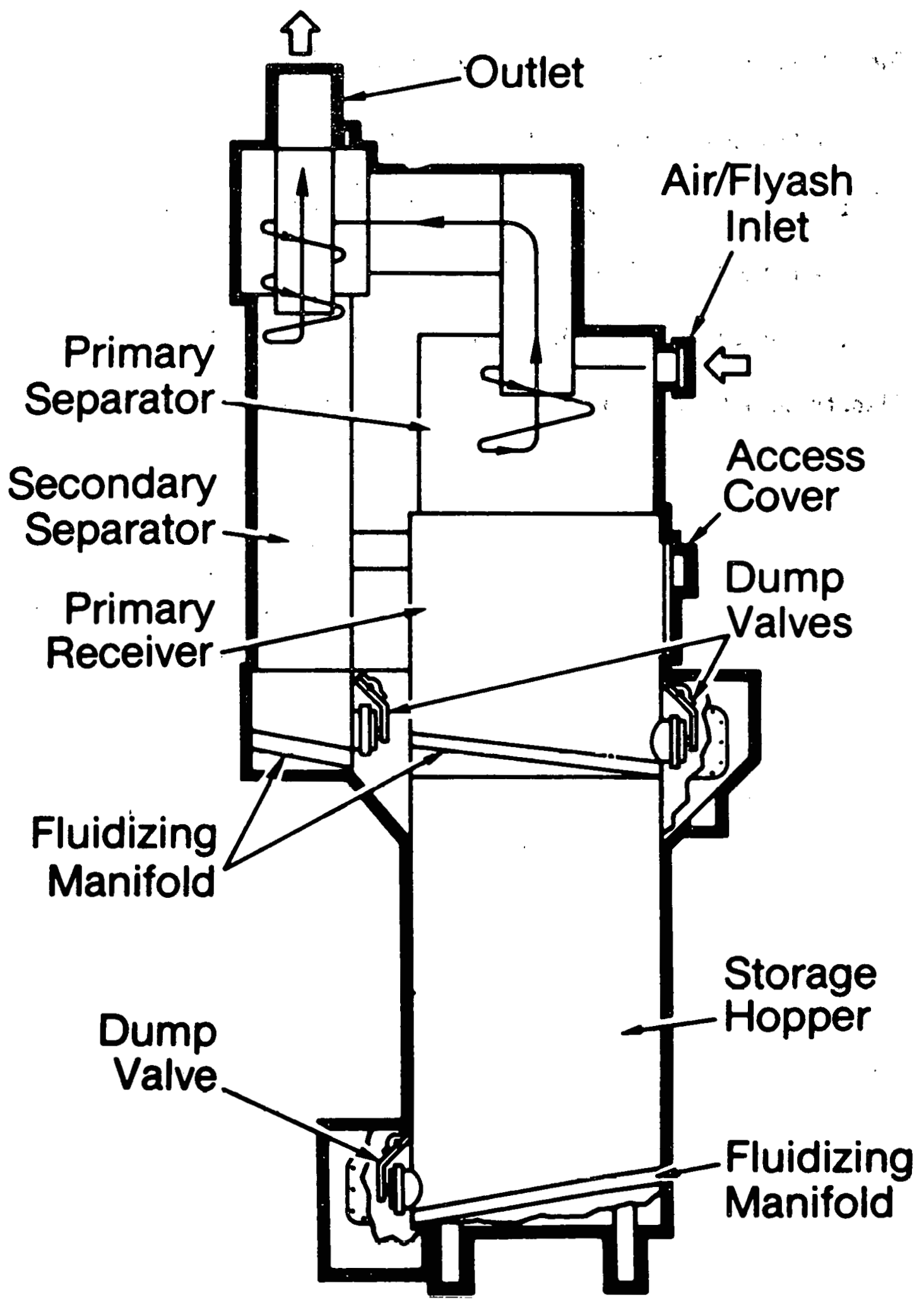

Dual-cyclone module for continuous separation of flyash and transport air (used on vacuumpneumatic systems). 
The Submerged Scrapper Conveyor System consists of:

1 - Process coil SSC with 5 hp drive

1 - Process coil SSC to bottom ash SSC gravity chute

1 - Bottom ash SSC with 5 hp drive

1 - Bottom ash SSC clinker grinder with $10 \mathrm{hp}$ drive

Also, track sufficient for 10 feet of SSC roll-away will be provided. 


$$
\text { SECTION VI-LIST OF DRAWINGS }
$$


List of Drawings

$\begin{array}{ll}\text { AD-823-025-0 } & \begin{array}{l}\text { Boiler Ash and Mill Rejects Removal } \\ \text { Hybrid Boiler }\end{array} \\ \text { 1)P-812-066-0 } & \text { Process Coil Support } \\ \text { EP-793-024-1 } & \text { Arrangement of C-E Rotary Ash Conditioner-Model } 36 \\ & \text { - Standard } \\ \text { EP-813-199-4 } & \begin{array}{l}\text { General Arrangement and Plan View } \\ \text { Hybrid Boiler - Illinois Design }\end{array} \\ \text { EP-823-139 } & \begin{array}{l}\text { Air and Gas Flow Schematic - Boiler } \\ \text { Hybrid Boiler - Illinois EDS }\end{array} \\ \text { EP-823-140 } & \begin{array}{l}\text { Clean-up System Gas Flow } \\ \text { Schematic - Hybrid Boiler }\end{array}\end{array}$




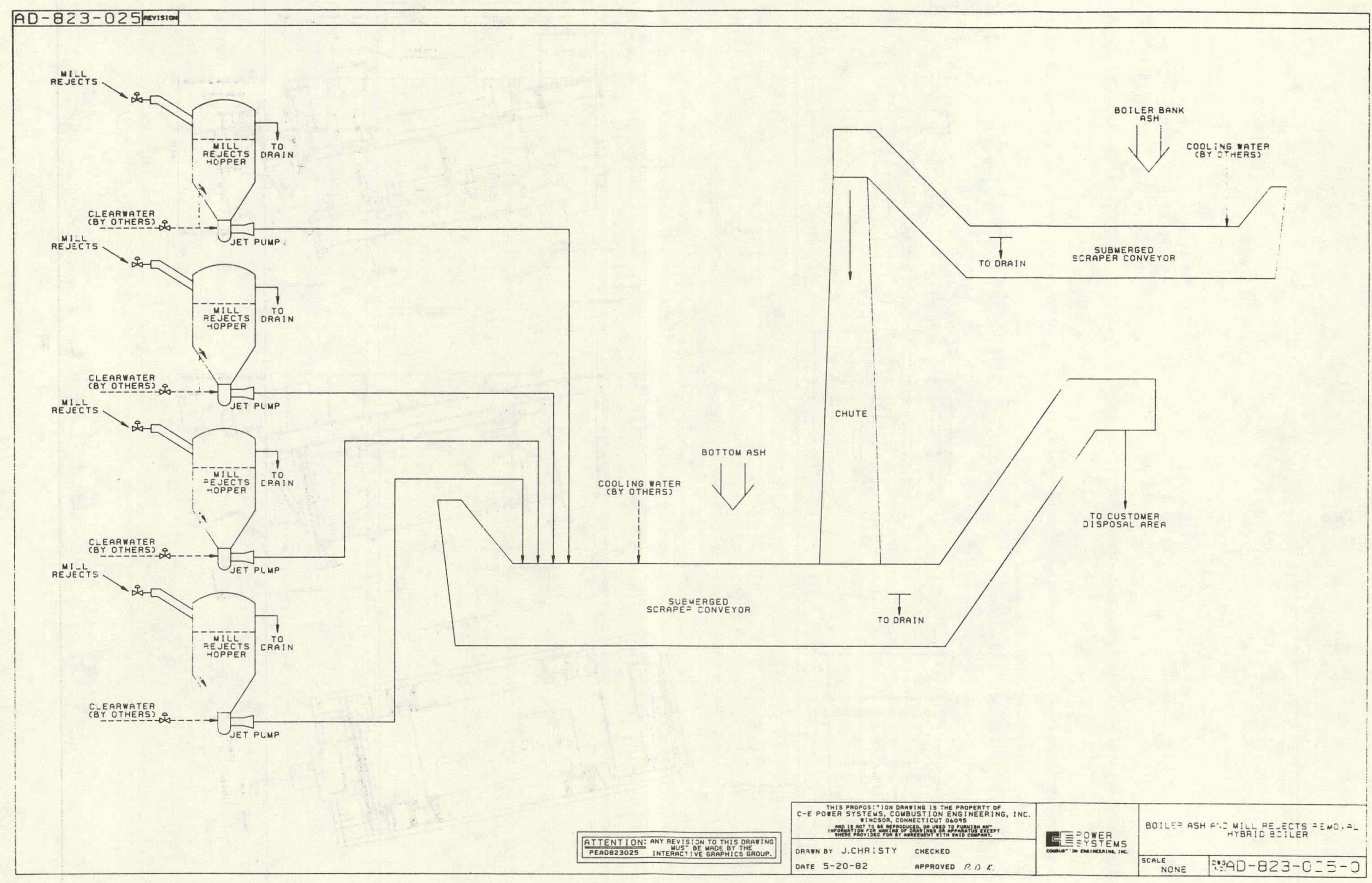




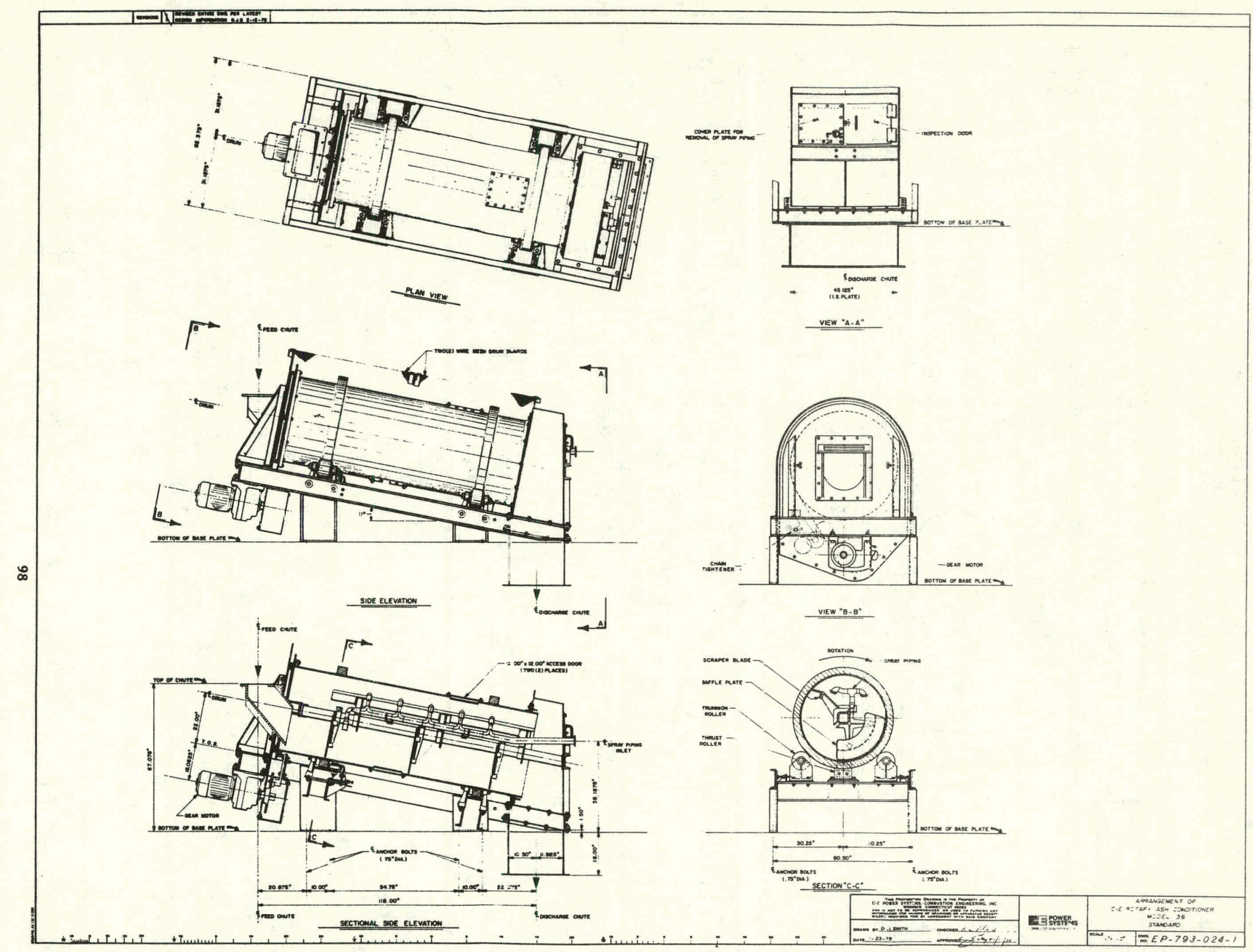




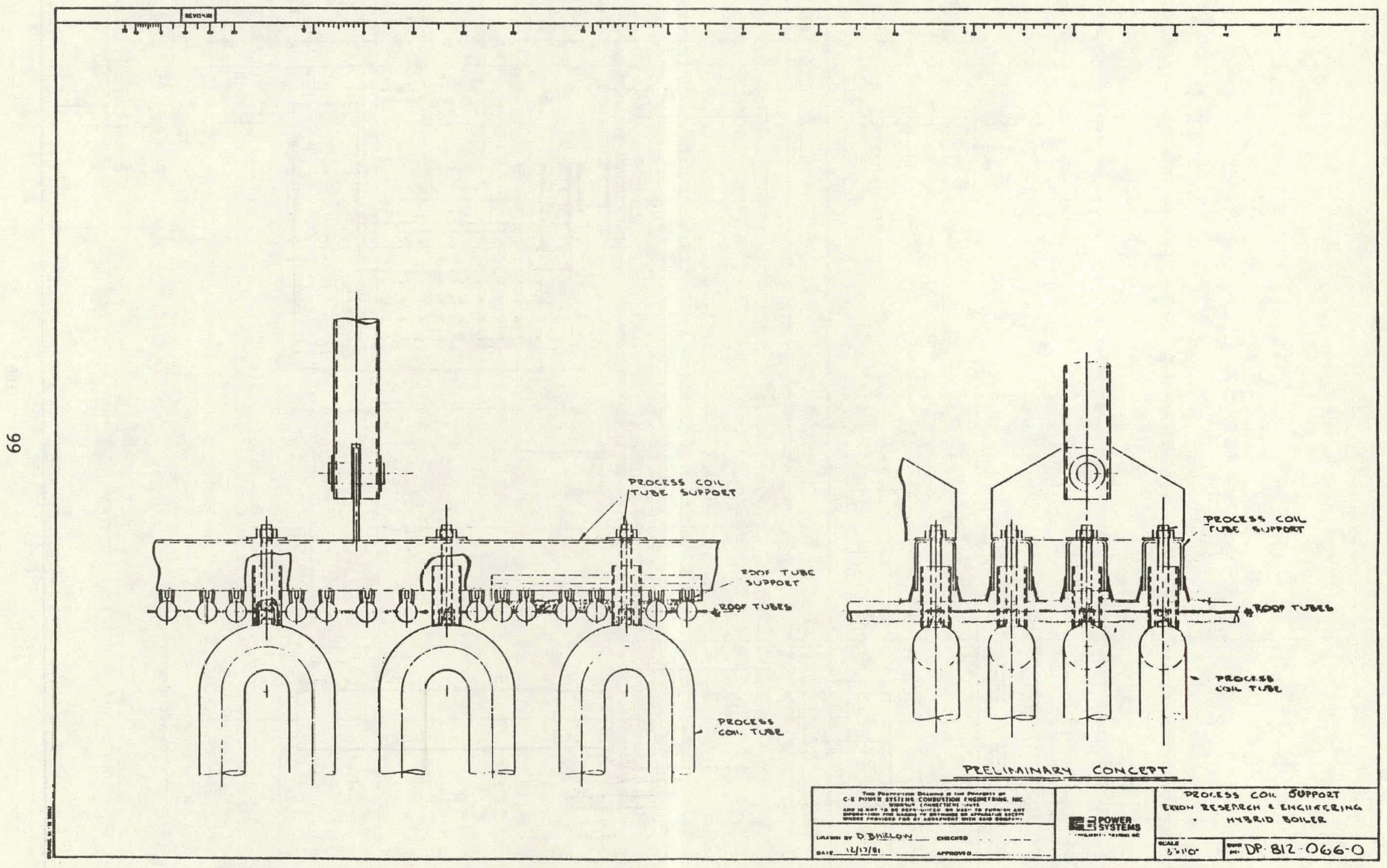




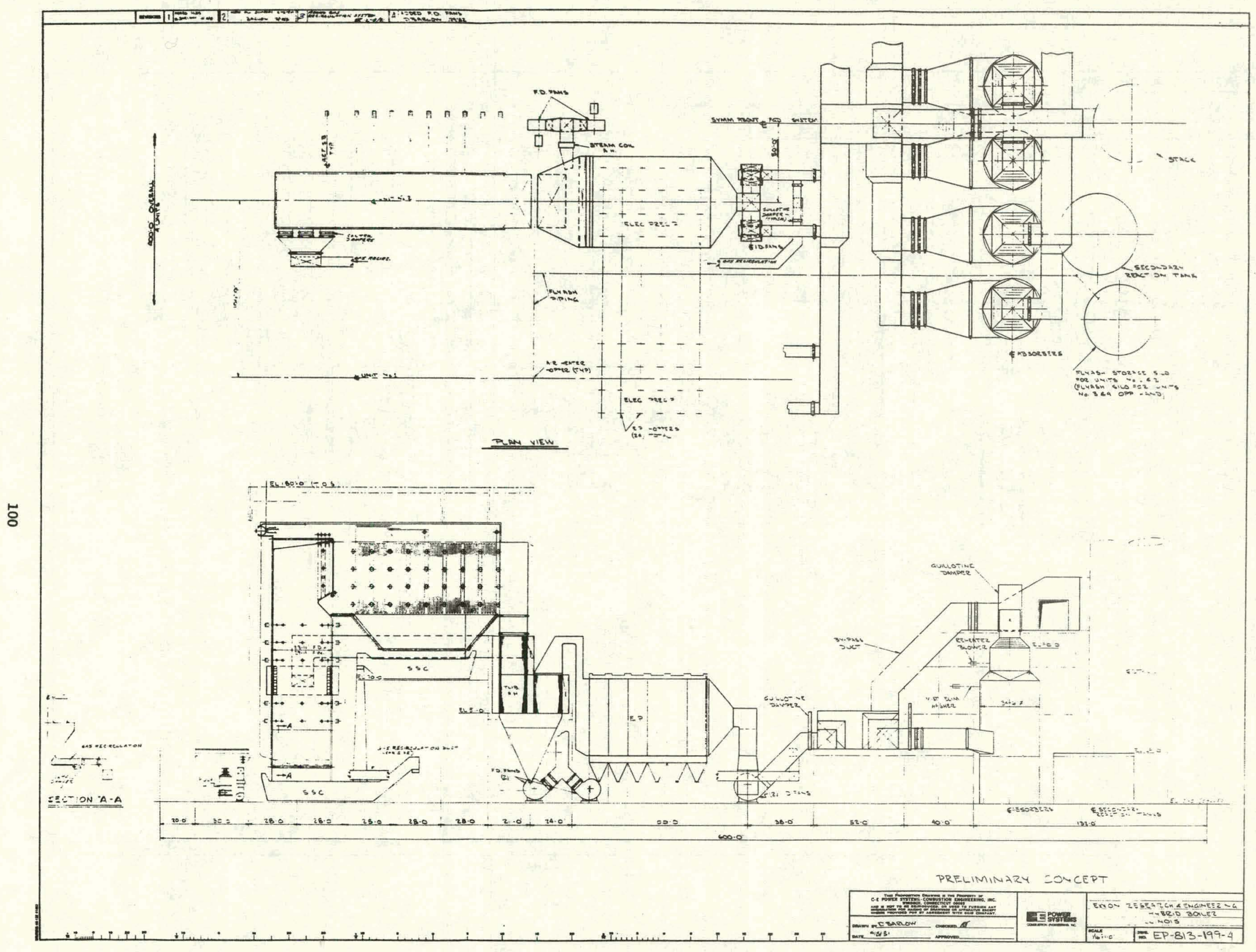




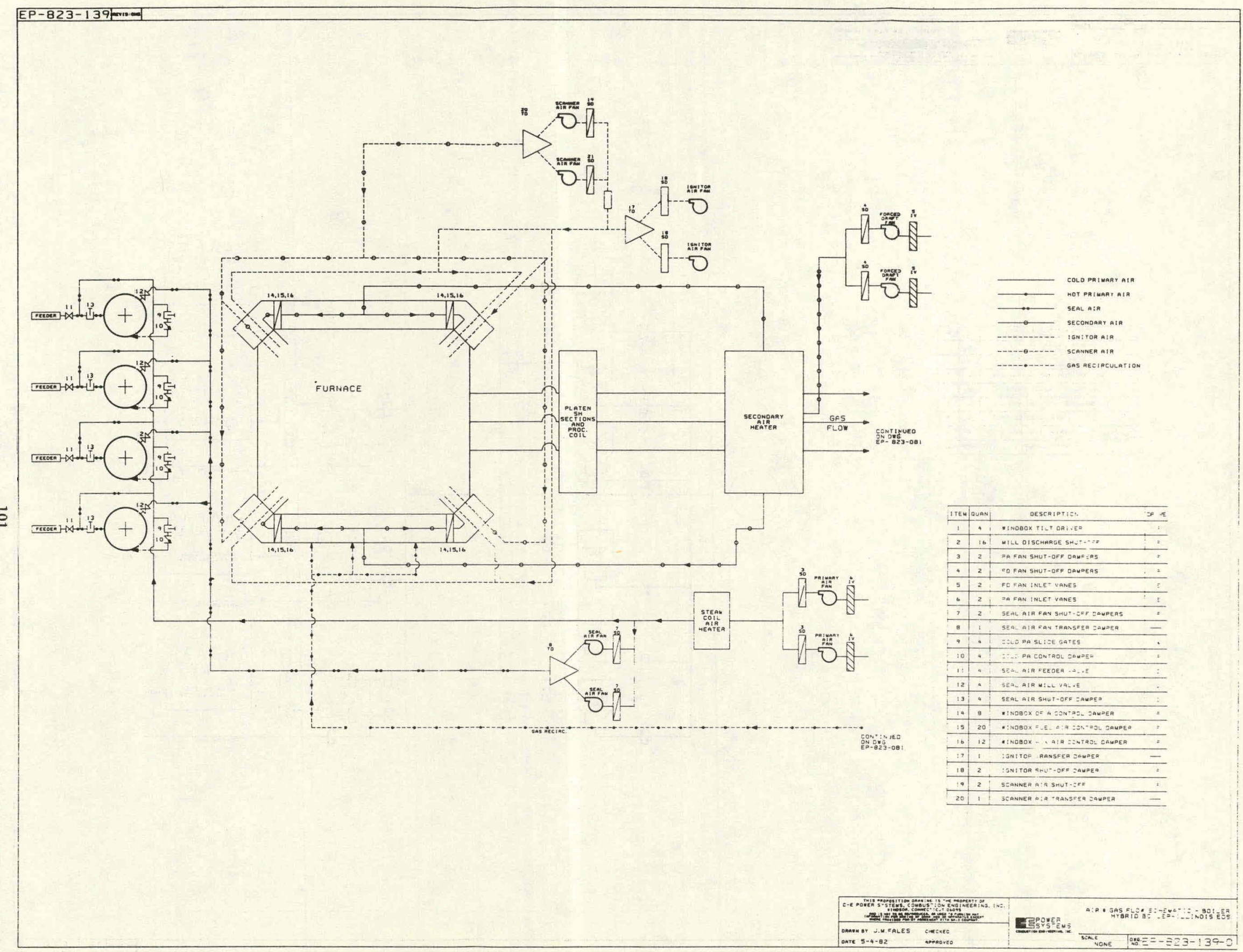




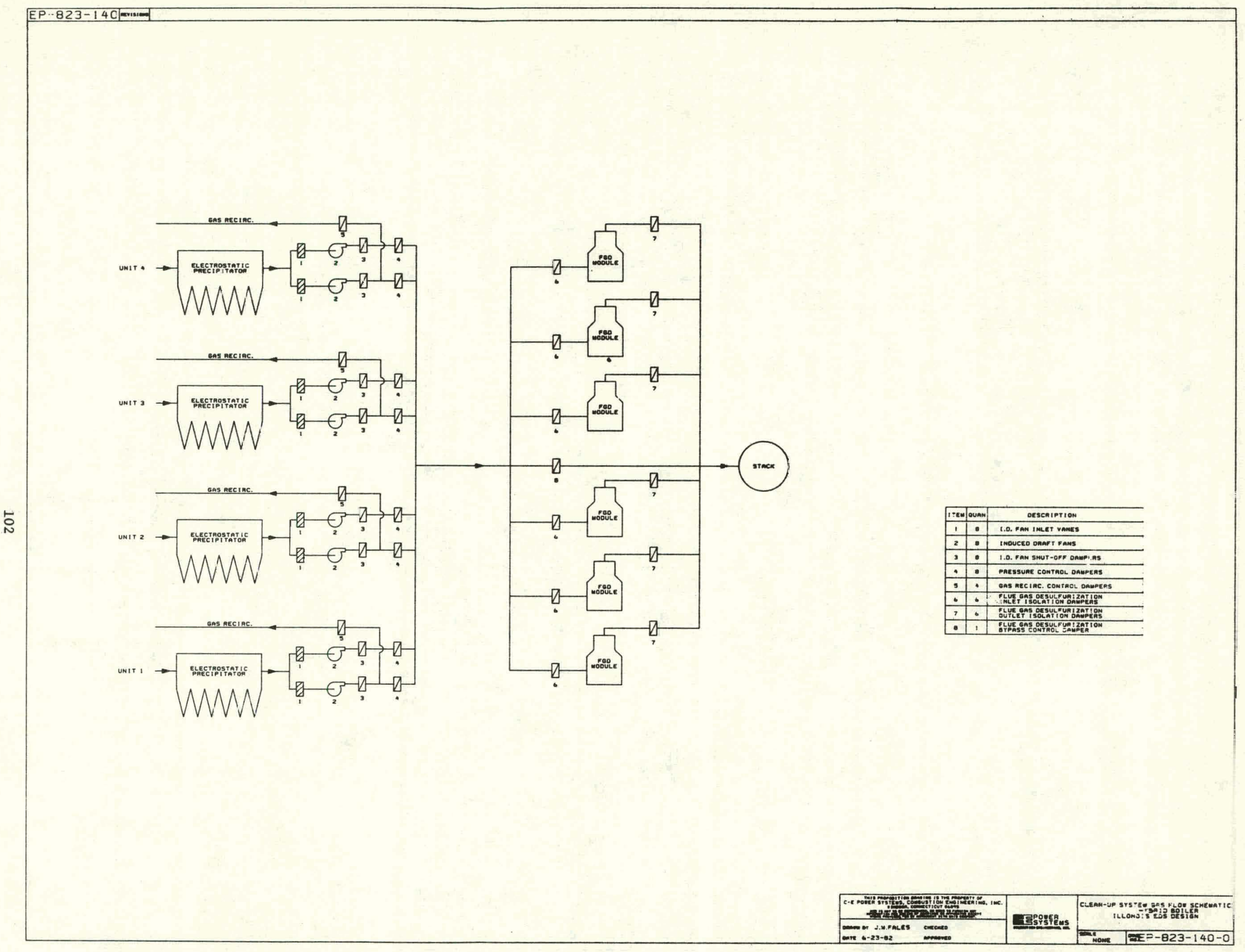


ADP: Availability Data Program

Assembly: Coplanar tubes in the direction of the gas flow.

BET: Brummer, Emmet, Teller

C-E: Combustion Engineering, Inc.

Circulation Ratio: The ratio of the mass flow rate of the water fied to the steam generating tubes to the steam flow rate generated.

Counter Flow: Flow type in which the hot end of the one fluid and the cold'of the other are in the same cross section, and vice versa.

Devolatilization: Reaction the coal undergoes when it is heated.

Volatile Matter $\stackrel{1100-1500^{\circ} \mathrm{F}}{\longrightarrow} \mathrm{CH}_{4}=\mathrm{Char}+\mathrm{HC}+\Delta \mathrm{H}$,

where $\mathrm{HC}$ indicates hydrocarbons higher than $\mathrm{CH}_{4}$ and $\Delta H$ the heat $\because$

released (exothermic reaction)

DNB: Departure from nucleate boiling

DTFS: Drop Tube Furnace System.

ECLP: EDS Coal Liquefaction Pilot Plant

Electrostatic Precipitator (ESP): Fly ash removal system.' Suspended

particles in the gas are electrically charged and then driven to collecting.

electrodes by an electrical field.

ER\&E: Exxon Research and Engineering Company

ESP: electrostatic precipitator

Fireball Flame Scanner: Flame monitoring device, detecting the presence or: absence of flame.

FD: forced draft 
Forced Draft Fan: Fan providing the required pressure to introduce the secondary air to the furnace.

FGD: Flue Gas Desulfurization System

Fouling: The adherence of ash on the convection surface.

FPTF: Fireside Performance Test Facility

FSSS: Furnace Safeguard Supervisory System

Furnace Height: From the centerline of the lower header to the furnace roof. Fusion Welding: Molten metal deposited by welding arcs between the tubes. Gas Recirculation (GR): Flue gas is taken from the main gas stream and reintroduced into the furnace. It is normally used for steam temperature rontrol.

ID: induced draft.

IFM Ignitor: Ionic Flame Monitoring Ignitor

Induced Draft Fan: Fan providing the required static head to assure flow of the combustion products from the furnace to the stacks.

KDL: Kreisinger Development Laboratory

KHB: Kentucky high volatile bituminous (coal)

LNCFS: low $\mathrm{NO}_{x}$ concentric firing system

Longitudinal Spacing $\left(S_{L}\right)$ : The distance between the centerlines of two consecutive tubes in the direction of the gas flow.

MCR: Maximum Continuous Rating (Full Load)

MTBF: Mean Time Between Failures

MTTR: Mean Time to Repair 
Net Heat Input (NHI): Net heat released inside the furnace; include the following:

i) Gross fuel heat input based on high heating value of the fuel.

ii) Sensible heat, calculated above $80^{\circ} \mathrm{F}$, contained in the fuel, preheated air and recirculated gas, and

iii) Heat content of the fuel atomizing steam above $80^{\circ} \mathrm{F}$ (when such steam is used).

From the previous items, the latent heat of vaporization of liquid water in the fuel and water formed from the hydrogen, along with the combustible loss are subtracted:

NHI/PA: Net Heat Input Per Plan Area OD: Outside Tube Diameter

Overfire Air: Air introduced at the top of the windbox

PA: primary air

Parallel flow: Flow type in which the hot ends of both fluids are in the same cross section.

Pendant Superheater: Tube assemblies hanging vertically to the direction of the gas flow.

Plan Area (furnace): Cross section of the furnace vertically to the direction of the gas flow; (width) $\times$ (depth).

Platenized Pendant: Assemblies with small longitudinal spacing (clear space between tubes small).

PM: pollution minimum

Primary Air: Air needed to transport and drying of the coal. 
Primary Air Fan: Fan providing the required static head for the Primary Air System.

Recuperative Air Heater (tubular): It utilizes the heat contained in the products of combustion to preheat the combustion air. It is essentially a nest of straight tubes expanded into tube sheets and enclosed in a reinforced steel casing. Air or gas are running through the tubes.

Regenerative Air Heater: In a rotating plate-type air heater, heat-storage plate elements are heated progressively in a flowing gas stream, and then rotated by mechanical means into an air stream where the stored heat is released.

$\underline{R_{C}:}$ Convective Heat Transfer Rate, $\frac{B t u}{h r-s q . f t .-F}$

$R_{n}$ : Non-luminous Heat Transfer Rate

$R_{t}$ : Total Heat Transfer Rate; $R_{t}=R_{c}+R_{n}$

Secondary Air: Air required for combustion of the fuel.

SGR: separating gas recirculation

SHO: superheater outlet

Slagging: Fused deposits or resolidified molten material that forms primarily on furnace walls.

SSC: Submerged Scraper Conveyor; Continuous Ash Removal System Steam Quality: Ratio of steam leaving to water entering the heated circuit. Quality is the inverse of the circulation ratio.

IGA: Thermogravimetric Analysis

TGS-2: Perkin Elmer Model TGS-2 thermogravimetric analysis apparatus Transverse Spacing $\left(S_{T}\right)$ : The distance between the centerlines of the consecutive assemblies. 